\author{
UNIVERSIDADE DE BRASÍLIA \\ CENTRO DE EXCELÊNCIA EM TURISMO \\ PROGRAMA DE PÓS-GRADUAÇÃO EM TURISMO
}

ANA PAUla CAETANO JACQUES

PATRIMÔNIO CULTURAL E ATRATIVO TURÍSTICO GASTRONÔMICO EM BELÉM DO PARÁ, BRASIL.

BRASÍLIA, DF

2015 


\author{
UNIVERSIDADE DE BRASÍLIA \\ CENTRO DE EXCELÊNCIA EM TURISMO \\ PROGRAMA DE PÓS-GRADUAÇÃO EM TURISMO
}

ANA PAULA CAETANO JACQUES

\title{
PATRIMÔNIO CULTURAL E ATRATIVO TURÍSTICO GASTRONÔMICO EM BELÉM DO PARÁ, BRASIL.
}

Dissertação de Mestrado apresentada ao Programa de Pós-Graduação em Turismo do Centro de Excelência em Turismo da Universidade de Brasília como requisito parcial para obtenção do Título de Mestra em Turismo.

Área de Concentração: Cultura e Desenvolvimento Regional

Linha de Pesquisa: Cultura e Sustentabilidade no Turismo

Orientador: Prof. Dr. Everaldo Batista da Costa 
Jacques, Ana Paula Caetano
J19p Patrimônio Cultural e Atrativo Turístico Gastronômico em Belém do Pará, Brasil. / Ana Paula Caetano Jacques; orientador Everaldo Batista da Costa. -- Brasilia, 2015.

$95 \mathrm{p}$.

Dissertação (Mestrado - Mestrado Profissional em Turismo) -- Universidade de Brasilia, 2015.

1. Turismo. 2. Patrimônio Cultural. 3. Gastronomia. 4. Cultura. I. Costa, Everaldo Batista da, orient. II. Título. 
ANA PAULA CAETANO JACQUES

\section{PATRIMÔNIO CULTURAL E ATRATIVO TURÍSTICO GASTRONÔMICO EM BELÉM DO PARÁ, BRASIL.}

Dissertação de Mestrado apresentada ao Programa de Pós-Graduação em Turismo do Centro de Excelência em Turismo da Universidade de Brasília.

Brasília, 7 de julho de 2015.

BANCA DE DEFESA DE DISSERTAÇÃO

Prof. Dr. Everaldo Batista da Costa

Presidente da Banca - Universidade de Brasília

Profa. Dra. Marustschka Moesch

Membro Interno - Universidade de Brasília

Prof. Dr. Leandro Benedini Brusadin

Membro Externo - Universidade Federal de Ouro Preto

Profa. Dra. Eloisa Pereira Barroso

Membro Interno - Universidade Federal de Ouro Preto 
Dedicamos este trabalho a todos aqueles que acreditam na valorização do saber-fazer tradicional e na diversidade da gastronomia brasileira. 


\section{AGRADECIMENTOS}

Entre as lembranças mais remotas da minha infância as mais marcantes relacionam-se com a alimentação e a satisfação que sempre senti em compartilhar uma refeição entre familiares e amigos. Para mim, a cozinha sempre foi o espaço da transformação e a mesa, o espaço do encantamento.

Ainda criança, algumas pessoas marcaram minha memória gustativa com seus saberes e fazeres entre elas minha avó Maria Esmeraldina (in memorian), meu avô Hélio (in memorian), minha tia-avó Heida, o tio Chico e a saudosa Firmínia, todos cozinheiros de "mão cheia”. Para vocês presto sinceros agradecimentos pois foi naquela memória que ancorei meu pensamento enquanto pesquisadora.

Dedico integralmente este trabalho ao meu pai Jair (in memorian) pois a partir de seu exemplo aprendi que talento não existe sem dedicação. Sua dedicação a uma causa somada ao talento em servir à pátria nos levou a percorrer os mais longínquos "rincões" do território brasileiro. Com base nessas andanças, tive a oportunidade de vivenciar múltiplas culturas e conviver com brasileiros de todo o Brasil e, assim, despertar minha inquietude com relação ao mundo e à diversidade da gastronomia brasileira.

À minha mãe, Iara, sempre visionária, meu agradecimento por acreditar nos meus projetos e ideais. Mesmo diante do improvável pedido de uma criança de oito anos, não se cansou até conseguir me matricular no meu primeiro curso de culinária. Sua dedicação como mãe, hoje, materializa-se nesta conquista e, por essa razão, ela é sua também.

Ao meu filho amado, André Felipe, que, ao longo desses anos dedicado ao Mestrado, tornou-se um homem com valores e princípios éticos. É gratificante perceber que o exemplo sempre é o melhor caminho para a educação dos filhos.

Ao meu companheiro e esposo, Frederico, que me incentivou a investir na gastronomia como um projeto de vida. Ser merecedora de seu orgulho é a maior das recompensas pois sem você nada disso seria possível.

Ao professor Neio Campos que abriu as portas da Universidade de Brasília e do Centro de Excelência em Turismo para mim e, na reta final, com sua sabedoria, disse as palavras certas na hora certa.

Ao meu orientador, Everaldo Costa, meu sincero agradecimento por sua generosidade e conhecimento. Seus questionamentos e sua humildade me conduziram a um novo mundo de descobertas. Espero honestamente ter sido merecedora das horas que dedicou ao processo de orientação. 
À professora Marustchka Moesch que ampliou meus horizontes sobre o Turismo. Com seus ensinamentos descobri as dimensões subjetivas e objetivas das experiências turísticas e um novo mundo de possibilidades.

Aos seres encantados da floresta Amazônica, agradeço por terem possibilitado o encontro com Tainá Marajoara, grande notória e símbolo da resistência frente à espetacularização da gastronomia paraense.

À Ana Rita Dantas Suassuna e Carlos Alberto Dória, ambos pesquisadores sobre a gastronomia brasileira, agradeço a disponibilidade pois os encontros que tivemos foram muito proveitosos para esta pesquisa.

A todos os professores do Centro de Excelência em Turismo, com atenção especial para Eloisa Pereira Barroso e Luiz Carlos Spiller Pena, agradeço as indicações de leitura e os debates interessados sobre minha temática.

Aos meus alunos, agradeço a curiosidade pois foram suas dúvidas e questionamentos que me fizeram pesquisar mais e buscar mais respostas.

Aos integrantes do Grupo de Pesquisas Cidades e Patrimonialização (GECIPA) agradeço o companheirismo nas densas leituras que me proporcionaram momentos de reflexão e aprendizado.

Aos colegas de mestrado, deixo minha sincera admiração pois compartilhamos as mesmas angústias e agora as mesmas alegrias.

Aos meus familiares e amigos, principalmente minha irmã Caroline, agradeço a compreensão pois o percurso foi longo e muitas vezes me afastou de todos vocês.

A todos os cozinheiros amadores e profissionais que transformam a gastronomia brasileira numa aquarela de cores, aromas e sabores, deixo meu respeito.

A Deus, por tudo isso existir. 
"Dis-moi ce que tu manges, je te dirais ce que tu es" (Brillat-Savarin, 1825). 


\section{RESUMO}

A gastronomia é indispensável ao turismo e turistas percorrem o mundo em busca do "exótico", ou seja, da cultura alimentar do outro. Com base nesse pressuposto, partimos do princípio da gastronomia enquanto expressão da cultura (de uma sociedade, de um grupo, de um individuo) e ao mesmo tempo resultado da praxis humana. Assumimos uma postura crítica frente à dinâmica da apropriação material e simbólica dos bens culturais que, no contexto de uma sociedade pós-moderna, reflete, a nosso ver, os anseios de agentes públicos e privados e, consequentemente, dos turistas. Assim, esta pesquisa procura analisar - a partir de uma concepção dialética entre a produção e o consumo de bens culturais - a expressão da gastronomia paraense como patrimônio cultural versus atrativo turístico. Diante do frénésie em torno do consumo da "gastronomia típica", a gastronomia paraense passa a integrar oficialmente o rol de produtos da oferta turística do Pará e, com isso, a capital do estado, Belém, desponta como espaço de produção e consumo do patrimônio cultural e da identidade gastronômica local. Dessa forma, procura-se estabelecer uma discussão a respeito da ressignificação da gastronomia paraense e sua valorização como "produto" a ser ofertado aos turistas pois ao ser promovida como atrativo turístico requer um esforço coletivo para que não seja transformada num simulacro da mesma identidade que expressa suas singularidades.

Palavras-chave: Gastronomia paraense; Turismo; Patrimônio cultural. 


\begin{abstract}
The cuisine is essential to tourism and tourists travel around the world seeking to experience the cuisine of other cultures. We understand gastronomy as a cultural expression (of a society, a group, an individual) and a result of human praxis. In post modern societies, the appropriation, both material and simbolic, of cultural goods reflects the needs of private and public agents and, thus, the tourists. Assuming a critical view of this phenom and accordingly to a dialetical conception that considers production and consumption of cultural goods, this research analyzes the Pará's gastronomy as a cultural heritage and a tourist attraction. Considering the increase consumption and a frenzy of typical cuisine, Pará's gastronomy has been added to the official list of tourist products in the state of Pará. Hence, Belém, capital of the state of Pará, stablishes itself as a producer and consumer of cultural heritage and gastronomic local identity. Therefore, this research discuss the ressignitification of Pará's gastronomy and its meaning as a "product" to be offered to tourists, in order to prevent its changing into a simulacrum of its own singularity.
\end{abstract}

Keywords: cuisine, gastronomy, tourism, cultural heritage. 


\section{LISTA DE FIGURAS}

Figura 1 - Localização de Belém do Pará, Brasil ..................................................................... 21

Figura 2 - Capa da reportagem que destaca Belém (PA) e "inclui" a cidade no mapa da

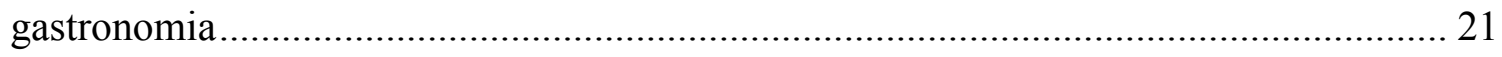

Figura 3 - Barraca de frutas nativas da região amazônica no Mercado Ver-o-Peso. ............... 23

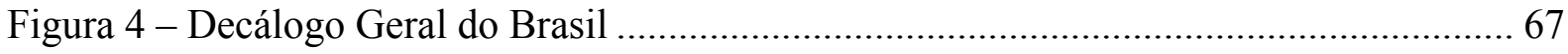

Figura 5 - Diversidade de farinhas nos mercados e feiras de Belém ................................... 71

Figura 6 - Preço da farinha e do açaí pesam no bolso do paraense......................................... 72

Figura 7 - Notícia que mostra o posicionamento de Belém no mapa da gastronomia............ 76

Figura 8 - As tacacazeiras integram o patrimônio cultural de Belém .................................. 78

Figura 9 - Comida típica é reconhecida como patrimônio cultural do Pará............................. 81

Figura 10 - O tucupi com o selo e assinatura do chef de cozinha Paulo Martins ................... 84

Figura 11 - Peixe no tucupi (prato servido no restaurante Maní em São Paulo)..................... 85

Figura 12 - Totem no saguão do Aeroporto Internacional de Belém Val-de-Cans................. 87

Figura 13 - O Tacacá paraense servido nas ruas de Belém................................................... 88 
$1 \quad$ INTRODUÇÃO ............................................................................................. 12

2 A GASTRONOMIA COMO PRÁTICA COTIDIANA E EXPRESSÃO CULTURAL

2.1 OS HÁBITOS ALIMENTARES DO HOMEM: CULTURA E NATUREZA . 25

2.2 A GASTRONOMIA COMO EXPRESSÃO CULTURAL ................................ 29

2.3 A GASTRONOMIA BRASILEIRA: IDENTIDADES CULTURAIS

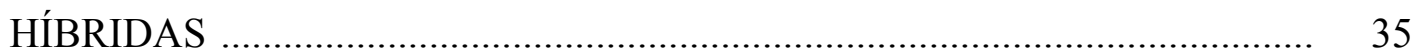

3 A INSTITUCIONALIZAÇÃO DA GASTRONOMIA COMO PATRIMÔNIO CULTURAL NO BRASIL

3.1 A INSTITUCIONALIZAÇÃO DO PATRIMÔNIO CULTURAL NO BRASIL 48

3.2 OS (DES)CAMINHOS DO SENTIDO DE PATRIMÔNIO 55

4 A VALORAÇÃo E A VALORIZAÇÃo DA GASTRONOMIA EM BELÉM DO PARÁ

4.1 A INSTITUCIONALIZAÇÃO DA GASTRONOMIA COMO ATRATIVO TURÍSTICO

4.2 AS PRÁTICAS E AS REPRESENTAÇÕES SIMBÓLICAS DA GASTRONOMIA EM BELÉM DO PARÁ 


\section{INTRODUÇÃO}

A gastronomia está cada vez mais imbricada à atividade turística. Viajar em busca dos "sabores" de um destino tornou-se uma tendência entre os fatores objetivos e subjetivos que motivam os turistas a planejar um roteiro turístico. Nesse contexto, ao mesmo tempo em que a gastronomia passa a despertar o interesse dos turistas, desperta o interesse dos agentes públicos e privados em gerar mais renda e lucro para os destinos (e para si próprios).

Acreditamos que essa dinâmica reproduz as condições da praxis humana, isto é, da existência na sociedade contemporânea ou pós-moderna pautada pelo consumo espetacularizado (DEBORD, 1997). Neste caso, o turista passa a colecionar experiências que reafirmam o "gosto" da própria sociedade, isto é, distinguem, classificam e ordenam as escolhas de cada grupo social (BOURDIEU, 1989). Um exemplo disso é o frénésie em torno do consumo da "gastronomia típica" e a incorporação dos elementos identitários da cultura alimentar à promoção nacional e internacional do destino Brasil e/ou suas regiões. Neste contexto, a capital do estado do Pará, Belém, destaca-se como espaço de consumo e produção de experiências gastronômicas "autênticas" e "originais".

Certamente, a gastronomia paraense é um elemento cultural que apoia a promoção turística do destino e não pretendemos negar o mérito desse elemento frente às expectativas dos turistas. No entanto, inquieta-nos a maneira com que os saberes e fazeres, as técnicas, insumos, comportamentos e códigos relativos à cultura alimentar dos paraenses vem sendo apropriados e espetacularizados para atender aos anseios de agentes públicos e privados e, consequentemente, dos turistas.

Portanto, a análise do processo de mercantilização desse patrimônio cultural requer uma postura crítica que supere a aparência inicial do fenômeno, a qual, a nosso ver, tende a pasteurizar a gastronomia pois, para ampliar o fluxo de turistas no destino, os lugares (e a cultura alimentar) são transformados ou adaptados para atender às expectativas dos turistas. Logo, identificamos que o deslumbramento em torno da gastronomia paraense está associado ao momento em que a cultura adquire valor de mercado e, por sua particularidade, atende as expectativas dos turistas que colecionam essas experiências gastronômicas "autênticas e originais".

Dessa maneira, propõe-se contextualizar a gastronomia como expressão da cultura de uma sociedade, formada e transformada pelos processos geo-históricos de ocupação do território e representada pelas múltiplas identidades nacionais, regionais. Além de trazer as marcas do passado, as manifestações gastronômicas presentes no território brasileiro, 
inserem-se em um processo dinâmico e acompanham as transformações da sociedade, hoje, produtora e consumidora de espetáculos.

Temos consciência de que essa transformação revela a tendência de hibridez que é atinente à nossa sociedade. Entretanto, a transformação do patrimônio cultural em mercadoria passa a atender a lógica do consumo e, pouco a pouco, tende a se tornar um simulacro daquela cultura que representava, originalmente, na história. É justamente nesse momento que inserese o debate sobre a valorização da gastronomia paraense como patrimônio cultural versus atrativo turístico. A abordagem aqui realizada diz respeito ao nível do mestrado profissionalizante, em que se valoriza a experiência empírica ou de trabalho da autora para o tratamento do tema que nos é tão instigante.

O estudo proposto busca compreender, conceitualmente, a gastronomia e também dedica-se a contextualizar suas ações simbólicas à teia de significados da cultura, ou seja, a análise dialoga um viés materialista com o papel da cultura e da vida de existência na formação social, como propõem Costa; Suzuki (2012a). Esses autores indicam a possibilidade de uma leitura social crítica materialista com a existencial e mesmo fenomenológica, o que é um grande desafio, pois significa ultrapassar a crítica dogmática, para a qual não há saída fora do materialismo dialético.

Nessa perspectiva, não aprofundaremos a investigação no viés existencial ou fenomenológico, propriamente ditos, mas no reconhecimento do lugar da cultura na produção material do mundo. Buscar-se-á o cuidado na relação entre autores que tratem desses dois vieses, de forma a evitar contradições e a não incorrer em equívocos no discurso, como ensinam Costa; Suzuki (2012a).

Com base nas definições de Geertz (1978), será interpretado o conjunto de práticas que permitem associar a gastronomia à teia de significados da cultura brasileira, uma cultura que é material e imaterial. Assim, como todo processo que envolve escolhas, percebe-se que a gastronomia brasileira revela as estruturas de classe e as relações de poder da sociedade ao longo da história. Segundo Bourdieu (2007), as distinções de gosto formam singularidades, na extensão do território, com sistemas classificantes e classificatórios dos estilos de vida correspondentes.

Procuramos avançar nas definições ideológicas que fundamentam a gastronomia brasileira como o amálgama do padrão alimentar legado por índios, brancos e negros. Parecenos oportuno afirmar que, até os dias atuais, o discurso ideológico da identidade nacional fundamentado no sincretismo cultural dessas três "raças" continua arraigado às interpretações sobre a gastronomia brasileira. Como destacam Costa; Suzuki (2012b), “esses bens precisam 
ser lidos como objetos híbridos da luta pelo controle territorial, e não como meras caricaturas da história do território".

Nesse ponto, sabendo-se das contradições existentes no cerne das relações interculturais, recupera-se o pensamento de Canclini (2001) para, dessa forma, reconhecer o hibridismo da gastronomia brasileira que configurou, ao longo do território, as múltiplas identidades culturais e gastronômicas, cada uma com suas singularidades e particularidades. Para o autor, o conceito de mestiçagem é insuficiente para explicar todas as formas de interculturalidade e "a palavra hibridação parece ser a mais que mais se adapta para conceituar não apenas as mesclas entre elementos étnicos ou religiosos mas, também, com produtos das tecnologias e processos sociais modernos e pós-modernos" (CANCLINI, 2001, p. 22, tradução nossa).

Assim, os processos de hibridação ocorrem em condições históricas e sociais específicas condicionadas pela relação entre produção e consumo existente em cada localidade. Vale lembrar que, em um mundo globalizado, as culturas não se limitam mais às fronteiras delineadas pelo Estado e, nesse cenário, as grandes cidades contemporâneas produzem novas relações entre o local e o global, o particular e o universal. Essas ideias corroboram na formulação de um olhar crítico sobre as expressões simbólicas da gastronomia paraense que a destacam no cenário nacional e internacional como atrativo turístico por suas características "autênticas" e "originais" conforme aponta o discurso oficial do Estado (BRASIL, 2011).

Seguramente, como diz Harvey (2005), essa gastronomia passa a interessar um conjunto de atores sociais que desejam ampliar sua renda em virtude das "qualidades especiais" e exclusividade do bem. Nesse aspecto, procura-se analisar a expressão da gastronomia paraense no momento em que a capital do estado desponta como centro de referência de consumo e produção desse patrimônio cultural e da identidade gastronômica local.

Nesse processo, busca-se — com base em investigação dialética — entre a produção e o consumo dos bens culturais, uma interpretação que supere a aparência inicial do fenômeno, rompendo com o mundo da pseudoconcreticidade, para citar Kosik (2002). No entanto, a busca pela totalidade concreta do fenômeno exige do pesquisador um détour, ${ }^{1}$ pois a essência da coisa ou "a coisa em si”, como lembra Kosik (2002), não se manifesta à primeira vista. Essa certeza requer uma mudança na postura ideológica em relação ao objeto a ser pesquisado

\footnotetext{
${ }^{1}$ Para Kosik, o fenômeno nunca se revela de imediato. Assim, é necessário fazer um détour, isto é, um desvio e assim cercando o fenômeno consegue-se revelar sua essência.
} 
pois seu entendimento na totalidade, na essência, baseia-se nos processos históricos que estão em constante movimento. Como ser histórico e, portanto, social, o homem define a realidade a partir de sua existência e exprime sua existência - a praxis humana- a partir da percepção que tem da realidade.

Sob essa concepção, a estruturação da gastronomia paraense como atrativo turístico é resultado e resultante da sua expressão como patrimônio cultural ou bem comum daquele grupo social. Tal premissa é percebida como dimensão da praxis e se constitui pressuposto fundamental para o método dialético da totalidade concreta. A totalidade, como evidencia Kosik (2002, p. 23), não representa o conjunto de todos os fatos e sim "um todo estruturado, dialético, no qual ou do qual um fato qualquer (classes de fatos, conjuntos de fatos) pode vir a ser racionalmente compreendido".

Kosik (2002, p. 50) mostra que, como seria impossível abranger todos os fatos, “o pensamento dialético parte do pressuposto de que o conhecimento humano se processa num movimento em espiral, do qual cada inicio é abstrato e relativo". Portanto, a realidade se configura num todo estruturado, dialético, e percorre um processo de concretização ${ }^{2}$ que possibilita a compreensão de um fato; neste caso, a análise das expressões da gastronomia em Belém como patrimônio cultural e atrativo turístico.

Se a realidade é um todo dialético e estruturado, o conhecimento concreto da
realidade não consiste em um acrescentamento sistemático de fatos a outros fatos, e
de noções a outras noções. E um processo de concretização procede do todo para as
partes e das partes para o todo, dos fenômenos para a essência e da essência para os
fenômenos, da totalidade para as contradições e das contradições para a totalidade; e
justamente neste processo de correlações em espiral no qual todos os conceitos
entram em movimento reciproco e se elucidam mutuamente, atinge a
concreticidade. (KOSIK, 2002, p. 50)

Como o détour necessário para compreensão do fenômeno nos termos propostos por Kosik (2002), estruturamos a pesquisa em três capítulos a fim de examinar os aspectos que possibilitam o reconhecimento da gastronomia paraense como patrimônio cultural e, com base nisso, elucidar a dinâmica social que possibilita sua apropriação por agentes públicos e privados para potencializar o turismo no estado. Acredita-se que esse percurso proporcionará interpretação da realidade concreta que se estrutura em um conjunto articulado e hierarquizado de fatos que refletem a própria realidade.

À primeira vista, observa-se o crescente interesse pelo consumo turístico da gastronomia paraense, isto é, dos saberes e fazeres, das formas de expressão e das práticas

\footnotetext{
${ }^{2}$ A totalidade concreta, segundo Kosik (2002), consiste no método de investigação da realidade social orientado pelo princípio de que cada fenômeno pode ser compreendido como momento do todo.
} 
simbólicas do patrimônio cultural e da identidade gastronômica local. Por outro lado, a investigação dialética revela a apropriação desses elementos simbólicos na oferta turística do estado consonante com a ideologia de uma sociedade produtora e consumidora de espetáculos.

Ciente desse cenário, a autora esteve na cidade de Belém, capital do estado do Pará, para participar das atividades da $13^{\mathrm{a}}$ edição do Festival Ver-o-Peso da Cozinha Paraense promovido pelo Instituto Paulo Martins ${ }^{3}$ entre os dias 10 e 14 de abril de 2013 com o objetivo de escrever uma matéria para um blog de gastronomia e subsidiar as pesquisas sobre o tema ${ }^{4}$. O roteiro da viagem foi estruturado com base nas informações do "pacote do evento", nos sites oficiais do governo do Pará e da capital, Belém, além de outros blogs, revistas e jornais.

O roteiro incluiu experiências elencadas como indispensáveis para os turistas que desejam realizar uma imersão pela gastronomia paraense: conhecer o tradicional Mercado Ver-o-Peso; passear pela Estação das Docas para experimentar as cervejas artesanais da Amazon Beer e os sorvetes da Cairu, ambos produzidos com ingredientes nativos; degustar os preparos clássicos do restaurante Lá em Casa e o inovador menu degustação do restaurante Remanso do Bosque. Entre os outros itens essenciais para "entrar de verdade na cultura do Pará" figuravam: eleger uma das tacacazeiras da cidade para tomar um tacacá no final da tarde e acompanhar a colheita do açaí na comunidade do Combu ${ }^{6}$.

A viagem contemplou a participação como ouvinte no "Fórum Turismo Gastronômico" que tinha como objetivo debater como a gastronomia como elemento para potencializar o turismo no estado ${ }^{7}$. Na palestra realizada pelo Secretário de Estado de Turismo do Pará foi possível identificar que o órgão oficial de turismo do estado é o principal agente que corrobora para a produção da gastronomia paraense como atrativo turístico do estado. Com base nisso, o "Ver-o-Pará" — Plano Estratégico de Turismo do Estado do Pará constitui o instrumento que subsidia e orienta o discurso oficial.

\footnotetext{
${ }^{3}$ O Festival Ver-o-Peso da Cozinha Paraense foi idealizado pelo paraense Paulo Martins (in memorian) com o objetivo de divulgar a diversidade e as tradições da gastronomia local para o restante do Brasil e do mundo. Por seu trabalho, o chef de cozinha foi intitulado informalmente "embaixador da cozinha paraense" e agraciado post mortem com a Ordem do Mérito Cultural do Ministério da Cultura na Classe Cavaleiro em 05 de novembro de 2014.

${ }^{4}$ A autora editava o blog Pitadas de Gastronomia e havia acabado de ingressar como aluna regular do Mestrado em Turismo na Universidade de Brasília (UnB).

${ }^{5}$ Em 2013, a agência Turismo Consciente comercializou o roteiro turístico-gastronômico oficial do Festival Vero-Peso da Cozinha Paraense.

${ }^{6}$ A ilha de Combu fica localizada na Bahia de Guarajá nas imediações de Belém do Pará.

${ }^{7} \mathrm{O}$ Fórum integrava a programação paralela do Festival Ver-o-Peso da Cozinha Paranse e foi promovido pelo Instituto Paulo Martins em parceria com o SENAC-PA.
} 
Portanto, a pesquisa se deu sobre a análise do discurso que fomenta a produção e consumo da gastronomia paraense presente nesse documento oficial. Tendo em vista o método dialético proposto por Kosik (2002), esse discurso não corresponde à totalidade dos fatos e tampouco nos possibilitaria apreender a essência do fenômeno. Portanto, utilizamos depoimentos que foram registrados durante a viagem a Belém (e em outra oportunidade) ${ }^{8}$, materiais promocionais disponíveis na internet e a própria experiência profissional da autora como forma de contornar e, ao mesmo tempo, nos aproximar do objeto de pesquisa.

O percurso que definimos vai ao encontro do pensamento de Gastal $(2005$, p. 78$)$ de que é necessário estar conectado às experiências que desejamos compreender. Enfatizamos que a íntima relação da autora com o tema possibilitou a formação de um olhar crítico sobre a tendência de valorização da gastronomia paraense como a mais autêntica e original do Brasil pois discurso que reforça esse imaginário está presente em seu cotidiano profissional.

Eu acrescentaria que, para entender os imaginários subjacentes à vida das pessoas, é importante estar muito conectado com a vida cotidiana do grupo que queremos entender melhor. Os imaginários contemporâneos estão presentes no cinema, na literatura e na música. Na televisão e na conversa numa mesa de bar. Conhecê-los é dar importância ao olhar, mas também ao ouvir. Portanto, conectar-se com imaginários significaria, entre outras coisas, ir ao cinema, ao teatro, a shows musicais, assistir à televisão, jogar conversa fora na mesa do bar. (GASTAL, 2005, p. 78).

Com vistas a dar o encaminhamento teórico necessário a essa análise, buscou-se realizar pesquisa bibliográfica ampla com base em autores que dialogam com a temática apresentada nesta dissertação. Com isso, o primeiro capítulo procura avançar no desenvolvimento de um conceito que possibilite situar a gastronomia no plano da cultura e do cotidiano, sustentado por autores como Clifford Hertz, Pierre Bourdieu, Zygmunt Bauman, Stuart Hall. Assim, busca-se compreender as formação de identidades gastronômicas híbridas no território brasileiro com base na leitura de autores como Darcy Ribeiro, Gilberto Freyre, Câmara Cascudo, Guy Debord, Renato Ortiz e Nestor Canclini.

Em segundo momento, percorremos os caminhos e descaminhos do patrimônio cultural no Brasil e, por meio de abordagem crítica não radical e perceptiva, vislumbramos as implicações da apropriação dos bens culturais para a produção e consumo em uma sociedade voltada para a produção e consumo de bens culturais.

\footnotetext{
${ }^{8}$ No decorrer desta pesquisa identificamos a relevância de buscar o depoimento de Tainá Marajoara, líder e fundadora do grupo Iacitata Amazônia Viva que atua diretamente nas comunidades com o objetivo de assegurar mecanismos de proteção para as tradições culturais relacionadas à gastronomia paraense. A entrevista foi concedida para a autora no dia 19 de abril de 2015 em Brasília-DF.
} 
Por fim, discutimos as categorias que ressignificam a gastronomia paraense em Belém e os elementos que favorecem a valorização da gastronomia paraense e que, assim, possibilitam que esta assuma, além do seu valor patrimonial, valor material. O patrimônio cultural, compreendido neste caso pelas expressões identitárias da gastronomia paraense, representa uma particularidade do saber-fazer alimentar brasileiro, em sua constituição histórica, o que vincula-se, sobretudo, com as nuanças da formação territorial nacional.

Acreditamos que a maior contribuição dessa pesquisa esteja na definição de um conceito que permita situar a gastronomia como elemento intrínseco ao cotidiano dos indivíduos vinculado às condições materiais de existência que confere identidade aos diversos grupos sociais e, por sua vez, compreende o amplo universo do patrimônio cultural brasileiro. Com isso, esperamos fornecer elementos que favoreçam a apreensão da gastronomia como expressão da cultura e que possibilitem compreender e refutar o discurso que continuamente atesta a gastronomia paraense como a mais autêntica e original do Brasil.

A contínua dinâmica das relações interculturais proporcionou aos brasileiros identidades gastronômicas híbridas e diversificadas ao longo do território. Assim, considerando-se esse contexto e ainda a necessidade de interpretação dialética entre a produção e o consumo de bens culturais a gastronomia paraense é reconhecida inicialmente como patrimônio cultural e importante elemento da identidade local. Portanto, a busca será pelos elementos que favorecem a expressão da gastronomia paraense como patrimônio cultural e atrativo turístico em Belém do Pará e sua relação com a produção e o consumo gastronômico de um patrimônio, o que confere dinâmica à atividade turística na cidade.

O objetivo geral da pesquisa proposta nesta dissertação consiste em analisar, sob a perspectiva da dialética entre a produção e o consumo dos bens culturais, a dinâmica existente entre a valorização e a valoração do patrimônio gastronômico como atrativo turístico do estado. Com base no propósito geral de compreender os aspectos que favorecem a apropriação material e simbólica do patrimônio cultural dos paraenses destacam-se três objetivos específicos que conduzem o détour necessário para se atingir a "pretensa" totalidade (verdade) levantada pela problemática desta pesquisa:

a) contextualizar a gastronomia no plano simbólico e material da cultura brasileira como forma de desvelar as singularidades da gastronomia paraense influenciadas por processos histórico-sociais de hibridação cultural e pelos padrões geográficos e seu reconhecimento como patrimônio da cultura local;

b) identificar os elementos que favorecem a construção de um discurso ideológico de valorização da gastronomia paraense como atrativo turístico no Pará; 
c) analisar, criticamente, a dinâmica entre a produção e o consumo - simbólico e material — da gastronomia paraense em Belém para potencializar o turismo no estado.

Compreendemos que a gastronomia de um povo constitui, também, representação material e simbólica de sua cultura e difere-se de uma sociedade para outra. Sobre esse pilar, cabe dizer que os homens não se alimentam, apenas, para satisfazer suas necessidades fisiológicas, mas para manifestar suas preferências de gosto e, ao mesmo tempo, legitimar as escolhas correspondentes ao seu grupo social (BOURDIEU, 1989).

De modo geral, a gastronomia brasileira costuma ser apresentada como o resultado da fusão alimentar entre indígenas, africanos e portugueses e, num segundo momento, ao miscigenado padrão alimentar do brasileiro teriam sido incorporados elementos das diversas nacionalidades que migraram para o país nos diversos períodos históricos, especialmente a partir da segunda metade do século $\mathrm{XIX}^{9}$. Assim, parece-nos simplificador descrever as singularidades culturais — e gastronômicas — que se delineiam ao longo do território brasileiro sob o olhar da miscigenação cultural, pois, como lembra Canclini (2001), esse conceito desconsidera as diferenças, os conflitos e as desigualdades em que ocorrem as mesclas interculturais.

Por outro lado, fala-se em gastronomia brasileira como processo finalizado, cristalizado no tempo, sem considerar que, como "produto" da cultura, situa-se no presente e, por essa razão, possui caráter dinâmico e está em constante transformação, pois resulta das práticas cotidianas das pessoas. Além disso, a gastronomia brasileira passa a ser compreendida como o resultado de contínuos ciclos de hibridação cultural — de acordo com os termos propostos por Canclini (2001) — nos quais as relações interculturais foram estabelecidas com base em estruturas sociais e relações de poder no contexto de um ideal colonizador.

Esse entendimento permite reconhecer o hibridismo da gastronomia brasileira e a formação de múltiplas identidades gastronômicas determinadas, inclusive, pelos padrões geográficos locais. Com base nessas distinções, o recorte dessa pesquisa consiste no caso da gastronomia em Belém do Pará (figura 1) no momento em que o patrimônio cultural paraense,

\footnotetext{
${ }^{9}$ A imigração subvencionada representou o estímulo para a vinda de imigrantes ao Brasil que se estendeu de 1870 a 1930 . No decorrer do tempo, a iniciativa que inicialmente havia sido subsidiada por fazendeiros - logo após a promulgação da Lei do Ventre Livre em 1871) — foi adotada como política estadual e federal. Os imigrantes se comprometiam com contratos que estabeleciam não só o local para onde se dirigiriam mas também as condições de trabalho a que se submeteriam (INSTITUTO BRASILEIRO DE GEOGRAFIA E ESTATÍSTICA, 2000).
} 
institucionalizado ou não, passa a ser apropriado como importante atrativo turístico com vistas ao desenvolvimento econômico e social do estado (informação verbal) ${ }^{10}$.

Figura 1 - Localização de Belém do Pará, Brasil

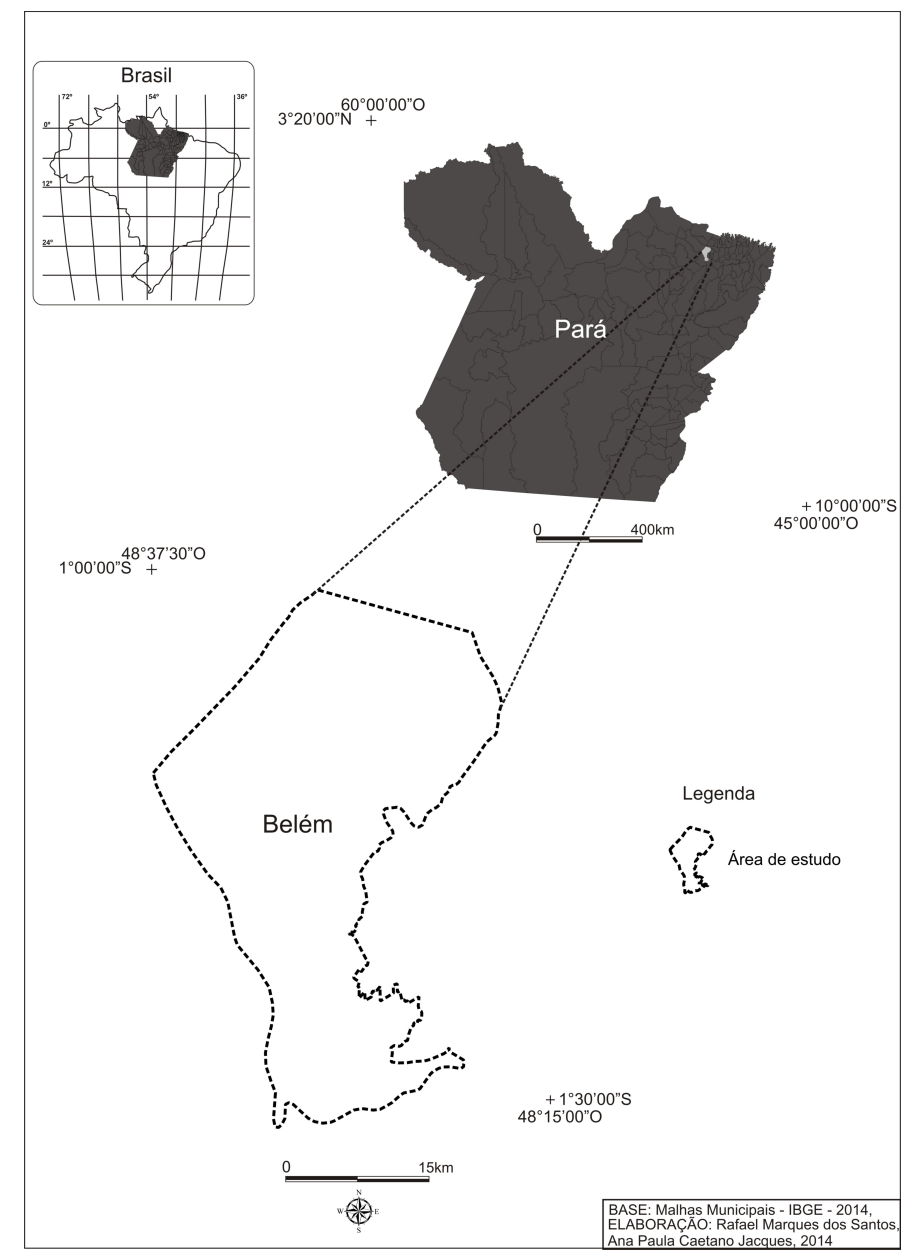

Fonte: Malhas Municipais (IBGE, 2014). Elaborado por Rafael Marques dos Santos e organizado por Ana Paula Caetano Jacques.

É importante destacar que essa informação é consoante ao depoimento do Secretário de Turismo do Estado do Pará $^{11}$ que reitera a profissionalização do turismo e da oferta gastronomia e nas ações de fomento e promoção da gastronomia paraense constantes no "Vero-Pará" - Plano Estratégico de Turismo do Estado do Pará 2012 - 2020 (BRASIL, 2011).

Figura 2 - Capa da reportagem que destaca Belém (PA) e "inclui" a cidade no mapa da gastronomia

\footnotetext{
${ }^{10}$ Informação concedida pelo Secretário de Turismo do Estado do Pará (Setur/PA), Adenauer Góes, na palestra proferida em 10 de abril de 2013 no "Fórum Turismo Gastronômico" realizado no Senac-PA durante a programação do Festival Ver-o-Peso da Cozinha Paraense.

${ }^{11}$ Palestra do Secretário de Turismo do Estado do Pará, Adenauer Góes, proferida no "Fórum Turismo Gastronômico" realizado no Senac-PA durante a programação do Festival Ver-o-Peso da Cozinha Paraense 2013.
} 


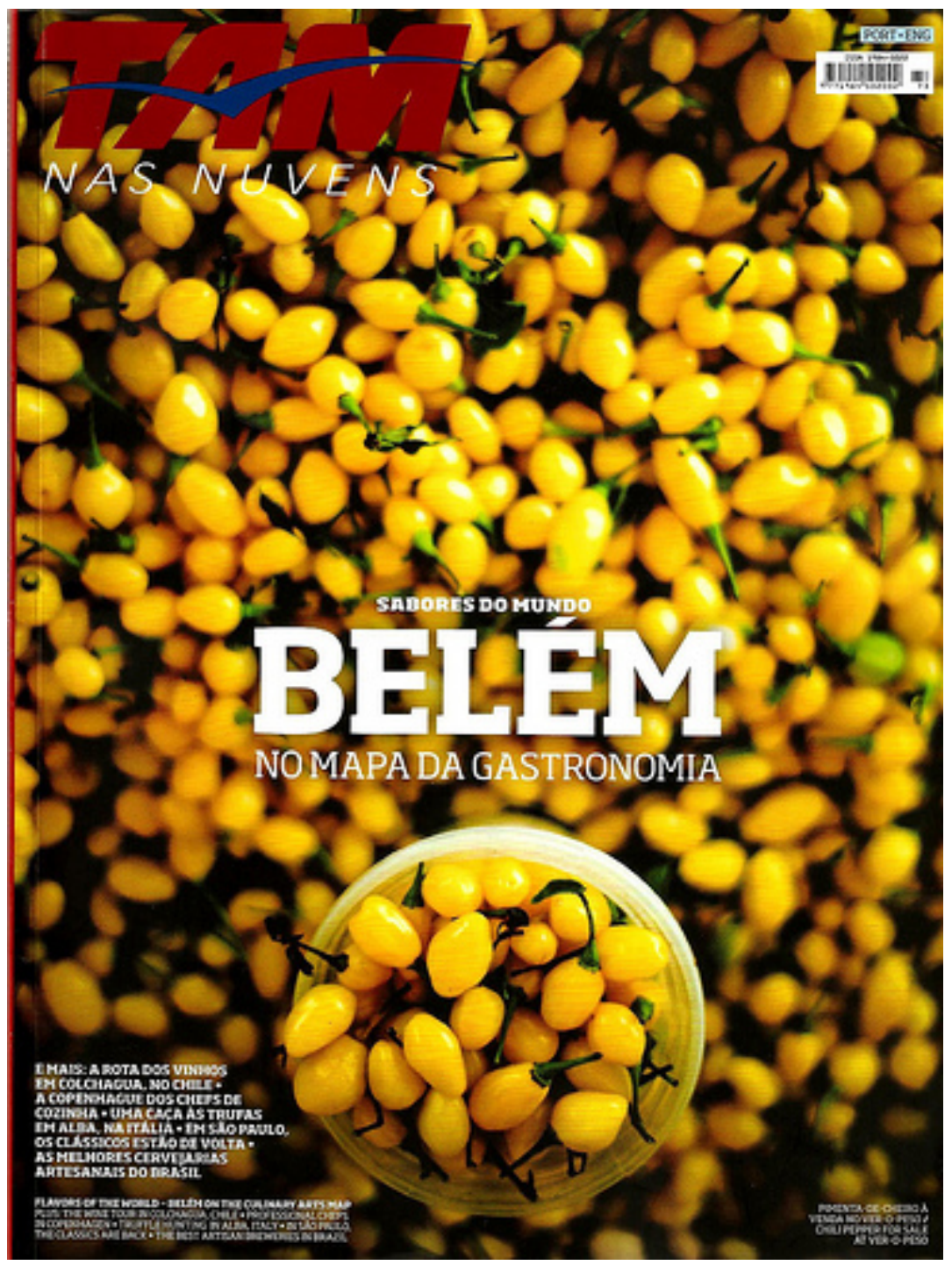

Fonte: Revista TAM Nas Nuvens, capa, Edição n ${ }^{\circ}$ 73, janeiro de 2014.

Nesse cenário, Belém, como capital do estado e, ao mesmo tempo, como um dos seis polos setoriais de desenvolvimento turístico do Pará ${ }^{12}$ concentra elementos diversos elementos que favorecem a expressão do patrimônio gastronômico paraense como atrativo turístico. Com isso, Belém adentra o "mapa" nacional e internacional do turismo gastronômico local, nacional, internacional (figura 2) como a "porta de entrada" ou "a última

12 Segundo o Relatório Executivo do Plano "Ver-o-Pará", o estado foi dividido em seis polos de desenvolvimento setorial: Belém, Amazônia Atlântica, Araguaia-Tocantins, Marajó, Tapajós, Xingu (BRASIL, 2011, p. 36). 
fronteira" para se ter acesso à "gastronomia mais autêntica do Brasil" ou ao estado que é "Obra-Prima da Amazônia". 13

Para melhor exemplificar essa questão, salientamos que, nos últimos anos, identificamos notória valorização dos elementos identitários da cultura alimentar paraense entre conceituados profissionais do setor gastronômico, incluindo, neste caso, chefs de cozinha que se destacaram nacional e internacionalmente na medida em que passaram a incorporar essas referências em suas criações. ${ }^{14}$ Por sua vez, o status recebido por esses profissionais parece ter potencializado o interesse pelo savoir-faire paraense e pela biodiversidade que se origina no curso dos rios e da floresta Amazônica, comercializados e produzidos, em Belém, nos restaurantes, feiras, ruas, eventos e no tradicional Mercado Ver-oPeso. ${ }^{15}$

Um exemplo disso é o box da dona Carmelita (figura 3) localizado no setor de frutas do Mercado Ver-o-Peso que há mais de 40 (quarenta) anos é conhecido pelos moradores por oferecer a maior variedade de frutas da região amazônica. Diante do intenso fluxo de turistas que parte em busca da identidade gastronômica do Pará, tornou-se ponto de referência para conhecer e experimentar algumas espécies da biodiversidade nativa como uxi, pupunha, bacuri, buriti.

Diante dos elementos identitários da gastronomia paraense, as práticas simbólicas associadas à biodiversidade nativa e às tradições alimentares locais foram potencializadas como atrativo turístico do estado e Belém passa a ser referência para consumo da identidade e do patrimônio gastronômico local. Portanto, ao mesmo tempo em que o patrimônio gastronômico paraense é apresentado como importante atrativo turístico para o estado, tende a ser transformado em mercadoria.

Figura 3 - Barraca de frutas nativas da região amazônica no Mercado Ver-o-Peso.

\footnotetext{
${ }^{13}$ O Plano "Ver-o-Pará" trabalha o slogan "Pará, a Obra-Prima da Amazônia" junto ao trade local, regional, nacional e internacional e o discurso dos agentes públicos e privados referencial a capital como portal de acesso ao Pará e à Amazônia (BRASIL, 2011).

${ }^{14}$ Entre os inúmeros restaurantes da capital, em 2013, o Remanso do Bosque, que oferece um conceito autoral das tradições paraenses, entrou na concorrida lista dos 50 melhores restaurantes da América Latina, publicação especializada da revista inglesa Restaurant.

${ }^{15} \mathrm{O}$ Mercado Ver-o-Peso está associado à história de Belém do Pará pois se estabeleceu às margens da Bahia de Guajará como o lugar de "ver o peso" dos produtos e gêneros que seriam comercializados e distribuídos na cidade.
} 


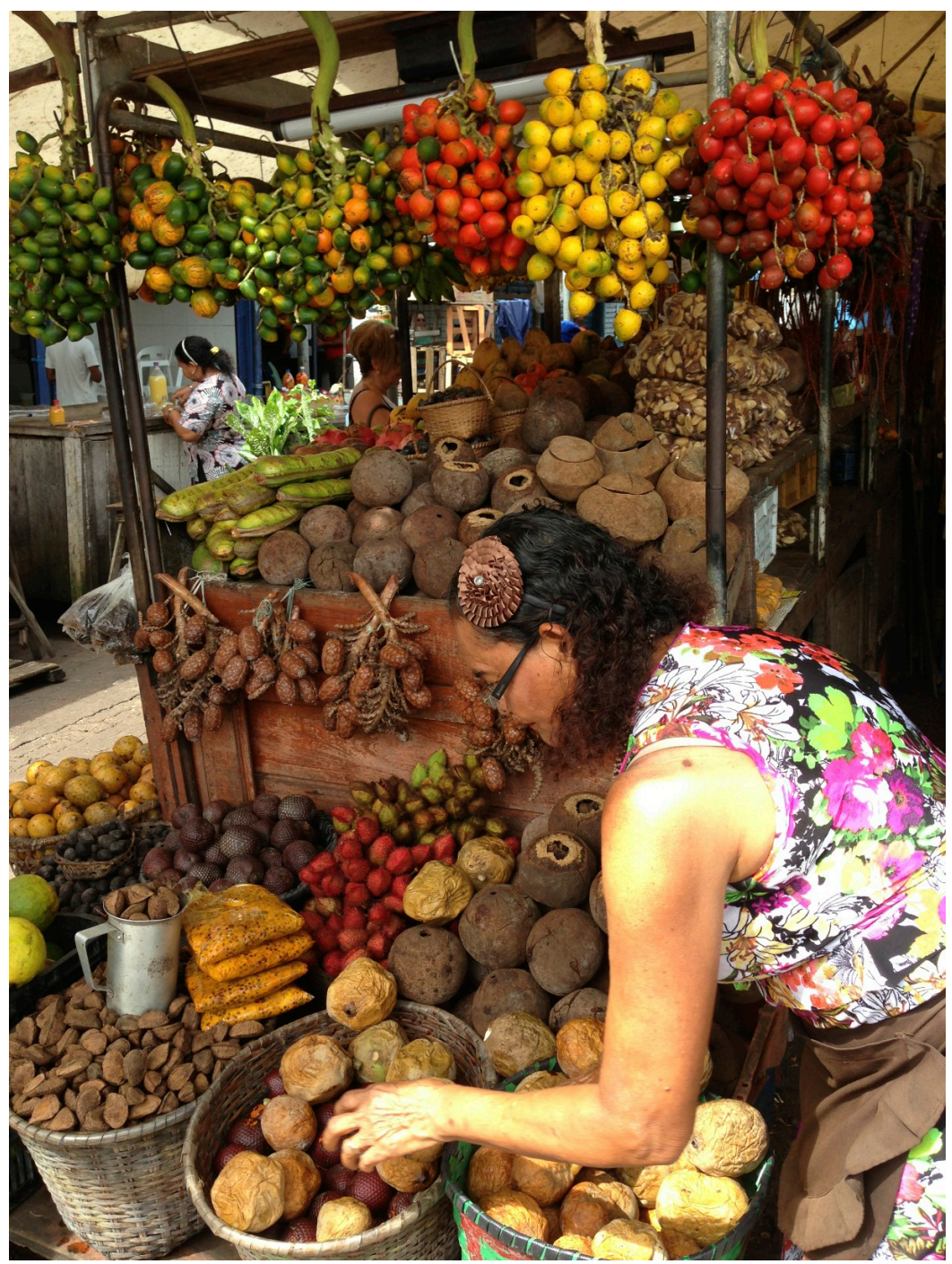

Fonte: foto da autora (abril de 2013).

Nesse cenário, os agentes públicos e privados apropriam-se do patrimônio cultural e da identidade gastronômica para promover uma "mercadoria" autêntica e original e investem na construção de uma imagem que favoreça essa associação no imaginário dos turistas.

Não é a imagem que produz o imaginário, mas o contrário. A existência de um imaginário determina a existência de um conjunto de imagens. A imagem não é suporte, mas resultado. Refiro-me a todo tipo de imagem: cinematográficas, pictóricas, esculturais, tecnológicas e por aí afora. Há um imaginário parisiense que gera uma forma particular de pensar a arquitetura, os jardins públicos, a decoração das casas, a arrumação dos restaurantes, etc. O imaginário de Paris faz Paris ser o que é. Isso é uma construção histórica, mas também o resultado de uma atmosfera e, por isso mesmo, uma aura que continua a produzir novas imagens. (SILVA, 2001, p. 76)

Maffesoli esclarece a Silva (2001, p. 76) que associação entre imagem e imaginário resulta de um processo cíclico onde a imagem decorre do imaginário e este, por sua vez, 
produz continuamente novas imagens. Portanto, a imagem da gastronomia paraense é resultado e resultante do imaginário individual que reflete o imaginário do grupo social.

No entanto, não se deve perder de vista o dilema apontado por Harvey (2005) sobre a valorização simbólica e material dos bens culturais "únicos e irreplicáveis" e a geração de renda monopolista que se sustenta sobre a "autenticidade e originalidade" desses mesmos bens. Assim, vale dizer que, ao reivindicar para si a imagem de que a gastronomia paraense "é a mais autêntica e original do Brasil", a aura contida nessa mensagem passa a compor o imaginário de que a gastronomia paraense se configura como a mais autêntica e original do Brasil.

Em resumo, o objeto empírico desta pesquisa consiste em analisar - sob a perspectiva da dialética entre a produção e o consumo dos bens culturais - os aspectos que favorecem a expressão da gastronomia como patrimônio cultural dos paraenses. A busca será por esses elementos de valorização e valoração do patrimônio e sua relação entre a produção e o consumo - simbólico e material — da gastronomia em Belém para potencializar o turismo no estado. 


\section{A GASTRONOMIA COMO PRÁTICA COTIDIANA E EXPRESSÃO CULTURAL}

\subsection{OS HÁBITOS ALIMENTARES DO HOMEM: CULTURA E NATUREZA}

Defende-se que a gastronomia de um povo constitui uma representação material e simbólica de sua cultura e difere de uma sociedade para outra. De fato, o homem conferiu valor simbólico à alimentação e não mediu esforços em busca da diversificação e codificação econômica, religiosa, social e cultural de seus hábitos alimentares. Sobre esse pilar, foge-se do entendimento que situa a gastronomia no plano das necessidades fisiológicas para então conceituá-la como fenômeno complexo que abrange todos os aspectos da vida humana.

Não restam dúvidas de que as escolhas alimentares expressam a ideologia e revelam o conjunto de códigos culturais de cada cultura. Ao mesmo tempo, refletem as estruturas de poder vigentes nos grupos sociais e, por esta razão, passam a identificar e diferenciar as culturas. Portanto, o compromisso em analisar um tema de dimensão universal como a gastronomia exige uma postura crítica sobre os conceitos que permeiam as ciências humanas e sociais e o senso comum. Neste caso, vale lembrar que a gastronomia não dispõe de um arcabouço teórico e de uma epistemologia própria. Assim, ampara-se na totalidade concreta do fenômeno "gastronomia" no qual o método dialético oferece o détour necessário para balizar a discussão no sentido de atingir sua essência e ao mesmo tempo revelar suas contradições.

A nosso ver, compreender o processo histórico que incorporou novos valores ao termo originado na Grécia antiga para exprimir a observação às "leis do estômago" corrobora para uma análise não-casuística do discurso. Com isso, pretende-se escapar da frequente discussão que vincula a palavra "gastronomia" aos "prazeres da boa mesa" para situá-la no plano representativo e simbólico das práticas culturais. Desse modo, observa-se ainda que a gastronomia revela um modo de vida, uma maneira de relacionamento do homem com a terra e os contínuos ciclos de hibridação cultural vivenciados por uma dada sociedade.

Deve-se considerar que o domínio do fogo, há cerca de 500 mil anos, ocasionou modificações profundas à vida humana. Como destaca Flandrin (1998, p. 30), costuma-se associar esse fato à transformação do homem em ser cultural a partir do momento em que desenvolve a culinária e, por sua vez, diferencia sua alimentação da dos animais. De acordo com o autor, "os historiadores da pré-história parecem admitir que, de início, o fogo foi utilizado para cozer os alimentos e só bem mais tarde foi empregado para outros fins". É com 
base nessa nova dinâmica em torno do alimento "cozido" que se identificam os primeiros aspectos simbólicos associados à alimentação.

A esse respeito, Lévi-Strauss (2004, p. 331) destaca que "a descoberta da culinária afetou profundamente as relações até então existentes entre o céu e a terra". Nesse ponto, o desenvolvimento da culinária consistiu, na interpretação do autor, no fato que diferenciou os homens dos animais. Ainda segundo Lévi-Strauss (2009, p. 22), “em toda parte onde se manifesta uma regra podemos ter certeza de estar numa etapa da cultura". Logo, com a conquista do fogo, o homem instituiu conjunto de códigos culturais e simbologias associado ao alimento cozido que o afastava definitivamente dos animais que não tinham a posse do fogo e tampouco a culinária.

Compreendida não apenas pela transformação do alimento cru em cozido, mas, também, pelas técnicas, utensílios e comportamentos, a culinária constitui, segundo LéviStrauss (1968) a atividade mediadora que permite ao homem sua passagem do estado "natural" ao "cultural". Na perspectiva do autor, o sistema culinário de uma sociedade representa uma linguagem "através da qual ela traduz inconscientemente sua estrutura" (LÉVI-STRAUSS, 1968, p. 411, tradução nossa).

Carneiro (2003, p. 21) reforça essa percepção ao destacar que "boa parte da matériaprima etnográfica é, pois, em torno da alimentação, eixo ao redor do qual as diferentes culturas estruturam a sua vida prática assim como muitas de suas representações”. Em outras palavras, pode-se dizer que os códigos alimentares adotados por determinada sociedade revelam inconscientemente suas estruturas sociais, econômicas, religiosas, isto é, sua cultura. Por sua vez, a cultura compreende os fatos do cotidiano como as maneiras de vestir-se, de produzir, de se alimentar.

Diante disso, o alimento - e todos os códigos intrínsecos a ele - firma definitivamente seu "lugar", isto é, seu espaço social no cotidiano das pessoas. Portanto, cabe dizer que nenhuma outra atividade é tão permanente e apresenta-se tão interligada ao homem quanto a alimentação.

Qualquer concepção do conjunto social no plano econômico ou metafísico, implica necessariamente o desenvolvimento dos processos aquisitivos da alimentação. Caça, pesca, a técnica das primeiras armadilhas neolíticas, barragens, cercos, acosso, envenenamento, conservação e transporte de víveres, determinam os primeiros atos reflexivos da inteligência humana. O disfarce, a simulação, o troféu, o bailado, a pintura e gravação rupestres, a representação animal, a imitação das vozes e dos rumores das bestas ariscas, esculturas, a emboscada, não foram fórmulas propiciatórias para a captura de alimentos? A arte pré-histórica é apenas um documentário plástico de conquista alimentar. Magia, canto, dança de roda, valem 
manobras para dominar a indispensável alimentação quando em estado natural, correndo, voando, nadando (CASCUDO, 2004, p. 339).

Flandrin (1998) mostra que as primeiras técnicas de cocção e conservação (secagem, defumação, torração, fermentação) decorrentes do desenvolvimento da culinária, além de retardarem o processo de decomposição dos alimentos ${ }^{16}$ ampliaram, significativamente, a gama de alimentos comestíveis e digeríveis ao homem. Claval (2007, p. 255) reforça essa ideia ao considerar que a maior parte de produtos que a natureza oferece espontaneamente se apresentam impróprios para o consumo humano e que a abundância de gêneros disponíveis na alimentação constitui reflexos do desenvolvimento das técnicas culinárias.

De modo geral, aceita-se que as condutas alimentares dos homens diferem-se da dos animais pelos códigos culturais associados aos alimentos. Considera-se ainda que, desde a aurora da humanidade (e do surgimento da culinária), os homens realizaram escolhas relacionadas à alimentação. Portanto, é importante dizer que "não apenas os homens depararam com alimentos diferentes, de acordo com as regiões, mas parecem ter procedido, em cada região, a uma seleção e escolha dos alimentos que a natureza lhes oferecia; escolhas que decorriam, aliás, da diversidade de sua cultura" (FLANDRIN, 1998, p. 29).

Perlès (1998, p. 51) considera que "a alimentação pré-histórica não responde exclusivamente às necessidades nutricionais" e que o homem pré-histórico orientava as estratégias econômicas com base em suas escolhas alimentares ao mesmo tempo em que era influenciada economicamente por elas. A autora considera ainda que, desde aquele período, os múltiplos aspectos que abrangem o relacionamento do homem com os alimentos expressam a ideologia e refletem as estruturas de poder vigentes nos grupos sociais e, por essa razão, passam a identificar e diferenciar as culturas.

Há que se considerar, ainda, que, embora o desenvolvimento da culinária tenha possibilitado um novo e diversificado repertório alimentar, com base nos condicionantes da escolha entre o que comer e o que não comer, alguns alimentos assumem o caráter de preceitos e interditos culturais, isto é, tornam-se tabus religiosos, sociais ou geográficos. Com isso, a alimentação assume seu pressuposto de elemento cultural identitário que se materializa no momento em que se escolhe - consciente ou inconscientemente — o que se vai comer. Esse processo de escolha é determinado por uma série de fatores (históricos, sociais,

\footnotetext{
${ }^{16}$ Destaca-se aqui o triângulo cru-cozido-podre estabelecido por Lévi-Strauss nos três primeiros volumes de sua obra Mythologiques - O Cru e o cozido (1964), Do mel às cinzas (1967) e Origem dos modos à mesa (1968) —, segundo o qual a culinária media a passagem do alimento cru (natureza) ao cozido (cultura) e ao podre (natureza).
} 
econômicos, políticos, geográficos) que é possível dizer que o alimento reflete a ideologia de cada indivíduo ou grupo social.

Para Carneiro (2003, p. 1), “a fome biológica distingue-se dos apetites, expressões dos variáveis desejos humanos e cuja satisfação não obedece apenas ao curto trajeto que vai do prato à boca, mas se materializa em hábitos, costumes, rituais, etiquetas". Conforme o autor, em qualquer análise sobre alimentação é necessário considerar a existência da sua contrapartida (a fome ${ }^{17}$ ), pois a história da alimentação consiste na história da luta pelo acesso ao alimento e esta não decorre estritamente da disponibilidade ou indisponibilidade de gêneros alimentícios nos períodos históricos e nas sociedades. A fome resultante, acima de tudo, da acumulação capitalista e da distribuição desigual do produto social (CARNEIRO, 2003).

\begin{abstract}
A fome contemporânea não se limita à fome causada pelos cataclismas naturais que destroem colheitas. É na distribuição que se concentra o problema do abastecimento alimentar contemporâneo, dado que os índices de produção crescem avolumando uma quantidade nunca antes vista de estoques disponíveis nos países ricos (CARNEIRO, 2003, p. 37).
\end{abstract}

Vale dizer que, ao dissociar fome e apetite, necessidade fisiológica e prazer, o homem conferiu valor simbólico ao alimento e, de fato, não mediu esforços em busca da diversificação e codificação econômica, religiosa, social e cultural de seus hábitos alimentares. Como se vê, "comer" constitui ato revestido de símbolos e significados da cultura e das estruturas de poder vigentes em uma sociedade. Como afirma Maciel (2005, p. 53), "na alimentação humana, natureza e cultura se encontram, pois se comer é uma necessidade vital, o quê, quando e com quem comer são aspectos que fazem parte de um sistema que implica atribuição de significados ao ato alimentar”.

Como ponto de partida para essa análise, o processo de escolha entre o quê, quando e com quem comer repleto de simbologias, ritos, tabus, tradições e traços culturais determinantes e determinados por processos histórico-sociais e geográficos será resumido sob o conceito gastronomia. Por sua vez, uma análise teórica sobre gastronomia pode envolver múltiplas dimensões, envolvendo desde o aspecto físiológico aos sistemas simbólicos de determinado grupo social, como lembra Carneiro (2003). As múltiplas abordagens possíveis para esse campo de estudo que não dispõe de uma epistemologia própria indicam a

\footnotetext{
${ }^{17}$ Entende-se a fome para além da carência biológica de alimentos que se manifesta em ciclos regulares e sim como a escassez alimentar que pode levar uma pessoa à morte por inanição ou desnutrição. É importante dizer que as carências específicas da desnutrição e subalimentação bem como as ações e políticas públicas relacionadas à superação dessas condições não pertencem ao escopo dessa pesquisa.
} 
necessidade de atenção especial no uso de termos e categorias e um delineamento preciso sobre o escopo da pesquisa com o objetivo de contornar, o que Carneiro (2003, p. 4) descreve como "amplitude desmesurada" do próprio tema.

\begin{abstract}
(...) Não obstante essa relativa escassez de fontes e bibliografia e a amplitude do tema, a alimentação vem se tornando um aspecto incontornável dos mais diversos estudos, e sua onipresença em todas as sociedades levou alguns dos maiores especialistas no assunto justamente a atribuir-lhe o papel de uma chave mestra, de uma prática universal reveladora de todos os demais aspectos, ideias e conflitos de todos os povos em todas as épocas (CARNEIRO, 2003, p. 4).
\end{abstract}

Assim, como esforço necessário para situar o conceito que se fará presente ao longo desta pesquisa, consideramos indispensável contextualizar a gastronomia como expressão da cultura de uma sociedade (de um grupo ou indivíduo). Esse percurso também consiste em uma das etapas do caminho delineado para atingir a essência do fenômeno.

\title{
2.2 A GASTRONOMIA COMO EXPRESSÃO CULTURAL
}

Laraia (1986, p. 45) destaca que "o homem é o resultado do meio cultural em que foi socializado". Segundo o mesmo autor, os aspectos morais e valorativos dos diferentes comportamentos sociais como o modo de rir, vestir e comer resultam do aprendizado, isto é, são produto de determinada cultura. Assim, consideramos que seus hábitos alimentares refletem e, ao mesmo tempo, são refletidos em sua cultura. Vale dizer, ainda, que esses códigos alimentares - reunidos nesta pesquisa sob o conceito gastronomia - são transmitidos pelas gerações anteriores e representam o conhecimento e as experiências acumuladas pelas sociedades ao longo da história. No entanto, é o homem que, no contexto do presente, ao utilizar sua criatividade e as tecnologias de sua geração, ressignifica e confere sentido a esse patrimônio cultural (LARAIA, 1986).

Cultura diz respeito aos diferentes modos de expressar a realidade entre aqueles que vivenciam uma dada dinâmica social (SANTOS, 1996). Por sua vez, Laraia (1986, p. 95) destaca que o homem "tem a capacidade de questionar seus próprios hábitos e modificá-los". Essa afirmação conduz para o entendimento sobre o caráter dinâmico da cultura, segundo o qual, é necessário reconhecer que cada sistema cultural — no ritmo que lhe é particular apresenta-se em constante mudança.

Claval (2005) é outro autor a destacar que a cultura consiste em uma herança construída com base nos elementos do passado; integra o presente uma vez que reflete a experiência individual frente aos acontecimentos cotidianos; incorpora os planos que as 
pessoas e grupos sociais imaginam para o futuro. Portanto, "a cultura deve ser entendida como uma noção dinâmica que conecta o homem ao passado, presente e futuro" (CLAVAL, 2005, p. 90, tradução nossa).

É possível ponderar que os hábitos alimentares dizem respeito não só àquilo que é tradicional, mas, às práticas inovadoras que se manifestam no cotidiano. Surge, portanto, a necessidade de se analisar a cultura segundo a concepção semiótica de Geertz (1978), na qual integra um sistema de representações simbólicas passíveis de interpretação. Para o autor, a cultura se apresenta como teia e se constitui num fenômeno social dinâmico no qual "as formas da sociedade são a substância da cultura”.

Segundo a concepção de Geertz (1978), a cultura se constitui num sistema que permeia o indivíduo em todas as suas ações. Significa dizer que os comportamentos das pessoas se estabelecem com base em códigos estruturados dentro do contexto cultural da sociedade na qual está inserida.

Como sistemas entrelaçados de signos interpretáveis [...], a cultura não é um poder, algo ao qual podem ser atribuídos casualmente os acontecimentos sociais, os comportamentos, as instituições ou os processos; ela é um contexto, algo dentro do qual eles (os símbolos) podem ser descritos de forma inteligível - isto é, descritos com densidade (GEERTZ, 1978, p. 24).

Nesses termos, a análise cultural da gastronomia implica, necessariamente, como afirma Geertz (1978), uma análise não casuística do discurso social. Como substância da cultura de um povo, a gastronomia deve ser descrita dentro de um contexto, o que significa dizer que é um sistema simbólico único — tanto para os que partilham seus códigos quanto para aqueles que não se identificam com eles.

Benedict (1972, p. 19) lembra que "as lentes através das quais uma nação olha a vida não são as mesmas que uma outra usa". Para a autora, o cientista social precisa assumir essa premissa se deseja entender os sentidos de uma realidade cultural para aqueles que a vivem e essa tarefa requer certa dose de firmeza e generosidade no olhar. Cabe dizer que para interpretar a gastronomia de determinada cultura, é necessário utilizar a lente da cultura que a produz.

Cada realidade cultural tem sua lógica interna, a qual devemos procurar conhecer para que façam sentido as suas praticas, costumes, concepções e as transformações pelas quais estas passam. É preciso relacionar a variedade de procedimentos culturais com os contextos em que são produzidos. As variações nas formas de família, por exemplo, ou nas maneiras de habitar, de se vestir ou de distribuir os produtos do trabalho não são gratuitas. Fazem sentido para os agrupamentos humanos que as vivem, são resultado de sua história, relacionam-se com as condições materiais de sua existência. Entendido assim, o estudo da cultura 
contribui no combate a preconceitos, oferecendo uma plataforma firme para o respeito e a dignidade nas relações humanas (SANTOS, 1996, p. 8).

Deve-se ter em mente que, desde sua origem, a palavra gastronomia foi acompanhada de um sistema simbólico estruturado naquele dado contexto histórico-social. Etimologicamente, a palavra deriva dos vocábulos gregos gáster (ventre, estômago) e nómos (conhecimento, leis) e sua utilização surgiu em observância aos rituais, técnicas e regras que caracterizavam a alimentação dos gregos na Antiguidade (FRANCO, 2004). Esses códigos foram apontados inicialmente no poema Hedypatheia ${ }^{18}$ que, como destacam Wilkins e Hill (2011, p. 11), revela muito sobre a estrutura da antiga cultura grega. Assim, associar a palavra gastronomia ao que se denominava "vida de luxo" confirma, a nosso ver, o entendimento de que a gastronomia é uma representação das dinâmicas culturais vigentes em cada sociedade.

Posteriormente, o termo gastronomie consagrou-se, na literatura francesa, ${ }^{19}$ como referência aos "preceitos de comer e beber bem, além da arte de preparar os alimentos para deles obter o máximo de satisfação" (FRANCO, 2004, p. 167). Desse modo, seu uso também se apresenta intrinsecamente relacionado aos conceitos estéticos conferidos aos hábitos alimentares. Com base na escolha dos alimentos e, também, nas maneiras como as pessoas se alimentam, em nosso entendimento, é possível identificar os sistemas valorativos que cada culturas confere à gastronomia.

Bourdieu (2007) nos permite observar que os preceitos intrínsecos sobre o "comer e beber bem" revelam as distinções estruturais das sociedades. Sob essa perspectiva, o gosto, em geral, as preferências alimentares, em particular, afirmam as posições ocupadas pelas pessoas nos espaços sociais e os estilos de vida correspondentes.

Por essa razão, em cada sociedade, os códigos culturais relacionados à alimentação passam a identificar os grupos sociais e servem, ao mesmo tempo, como agentes de agregação e segregação. Desse modo, o processo de escolha "do quê, quando e com quem comer"

\footnotetext{
${ }^{18}$ A partir das viagens realizadas por mais de 60 cidades da Grécia antiga e áreas próximas (incluindo o sul da Itália, Sicília, costa da Ásia Menor e Mar Negro), Archestratus descreve em Hedypatheia - traduzido do grego antigo para "The Life of Luxury" - as experiências gastronômicas vivenciadas nesses locais e ocupa-se de relacionar uma série de técnicas e regras necessárias ao que entendia ser a "boa" alimentação da época, além de indicar os melhores locais para compra, consumo e preparação de alimentos no antigo mundo grego. Sua obra (62 fragmentos do texto original) foi transcrita no Banquete dos Sofistas de Ateneu (Deipnosophistae, Athenaeus) (WILKINS; HILL, 2011).

${ }^{19}$ É importante destacar que, entre o século XVII até as primeiras décadas do século XX, o francês predominava na sociedade europeia como língua franca universal sobretudo na política, diplomacia e ciência. Dessa forma, em 1825, o livro Physiologie du goût de Brillat-Savarin ocupa-se de generalizar na literatura a relação entre a gastronomia e a "boa alimentação" como, por exemplo, no trecho em que a descreve como "o conhecimento fundamentado de tudo o que se refere ao homem na medida em que ele se alimenta. Seu objetivo é zelar pela conservação dos homens por meio da melhor alimentação possível” (BRILLAT, 1995, grifo nosso).
} 
perpassa a ideia de gosto no sentido stricto, comportamento predominantemente inato e restrito ao aspecto fisiológico, e avança em direção ao sentido proposto por Bourdieu (1989, 2007), em que o gosto abrange todas as dimensões da vida humana que implicam alguma escolha.

Claval (2007, p. 256) sugere que "as razões pelas quais os homens dão tanta importância ao que comem e bebem, e lhe consagram parte importante de seu tempo, de sua energia e de suas rendas, não são todos resultado da fisiologia". Sobre esse pilar, cabe ressaltar que os homens não se alimentam, apenas, para satisfazer suas necessidades fisiológicas básicas, mas para manifestar suas preferências de gosto e, ao mesmo tempo, legitimar as escolhas correspondentes ao seu grupo social, como aponta Bourdieu (1989, 2007).

Como toda a espécie de gosto, ela une e separa: sendo o produto dos condicionamentos associados a uma classe particular de condições de existência, ela une todos aqueles que são o produto de condições semelhantes, mas distinguindo-os de todos os outros e a partir daquilo que têm de mais essencial, já que o gosto é o princípio de tudo o que se tem, pessoas e coisas, e de tudo o que se é para os outros, daquilo que serve de base para se classificar a si mesmo e pelo qual se é classificado (BOURDIEU, 2007, p. 56).

Com isso, pode-se dizer que o objeto a que se refere a gastronomia está profundamente relacionado à percepção que o homem faz de si em relação ao outro e à forma como ele se apropria dos elementos da cultura na qual está inserido. A rigor, a comensalidade figura como conjunto de práticas consideradas próprias da civilização humana. Era classificada no sistema de valores das antigas civilizações gregas e romanas como o primeiro elemento de distinção entre o homem civilizado e os bárbaros, como aponta Montanari (1998). ${ }^{20}$ Nesse contexto, aqueles que não seguiam o conjunto de códigos de "boas maneiras no banquete" eram identificados como selvagens. Por outro lado, os estudos sugerem que, desde o terceiro milênio a.C., a comensalidade assumiu função social capaz de expressar as hierarquias vigentes e as relações estruturais dos homens com os deuses e com os outros homens (FLANDRIN; MONTANARI, 1998).

Com efeito, a comensalidade representa mais do que o ato de realizar as refeições em comum, pois os códigos que acompanham o momento da partilha como o lugar de cada

\footnotetext{
${ }^{20}$ Montanari enfatiza que os conceitos de civilização e barbárie estão relacionados à noção de cidade como local privilegiado em oposição ao universo desconhecido entre os citadinos que seguem as normas de comportamento nos banquetes os diferencia dos selvagens ou semisselvagens que não as praticam ou praticam ocasionalmente (MONTANARI, 1998, p. 108).
} 
conviva à mesa e os alimentos que são oferecidos a eles exprimem o habitus ${ }^{21}$ e os estilos de vidas classificados e classificantes, para citar Bourdieu (2007). Ao mesmo tempo, evidenciase que os estilos de vida, isto é, os traços distintivos entre os grupos sociais (gosto) condicionam a apropriação material e/ou simbólica de determinado conjunto de objetos e as práticas sociais correspondentes.

Sobre essa dimensão simbólica, Bourdieu (1989) afirma que as pessoas e os extratos sociais se distinguem pela maneira como as pessoas usam os bens materiais e simbólicos de uma sociedade, conforme o acesso a esses bens, dando sentido ao mundo social. De certa forma, existe infinidade de alimentos que atendem as necessidades fisiológicas do homem, mas é significativo que o gosto é determinante para definir o que é classificado como comestível ou não comestível para um grupo social e para outro. Os tabus alimentares, por exemplo, orientam a escolha entre alimentos proibidos e permitidos e "servem como rituais instauradores de disciplinas, de técnicas de autocontrole que vigiam a mais insidiosa, diuturna e permanente tentação" (CARNEIRO, 2003, p. 119). Por meio dessa lógica, os diversos grupos comunicam (entre os seus e para os outros) suas identidades culturais.

Ao analisar a aceitação ou rejeição de determinados alimentos, Claval (2007, p. 257) destaca que as sensações provocadas por eles podem causar sentimentos conflitantes em virtude das experiências adquiridas na infância ou em outros momentos da vida da pessoa. Por essa razão, afirma que a socialização ocorrida na infância forma as primeiras e mais sólidas referências alimentares. Certamente, Bourdieu (2007, p. 76) concorda com esse pensamento ao dizer que, nos gostos alimentares encontra-se, "a marca mais forte e inalterável das aprendizagens primitivas, aquelas que sobrevivem mais tempo ao afastamento e desmoronamento do mundo de origem". Freyre (2007, p. 34), por sua vez, afirma que o gosto é condicionado, "nas suas expressões específicas, pelas sociedades a que pertencemos, pelas culturas de que participamos, pelas ecologias em que vivemos os anos decisivos da nossa existência".

Nesse ponto, cabe ressaltar que os códigos culturais são transmitidos como herança para as próximas gerações e a apropriação (ou rejeição) desses saberes ocorre em diversas etapas da vida da pessoa por meio de repetições ou da transmissão oral e escrita, isto é, de sistemas de comunicação que, por estarem inseridos no contexto de uma cultura, também servem como instrumento de legitimação desses mesmos símbolos (BOURDIEU, 1989).

\footnotetext{
${ }^{21}$ Habitus consiste no conceito definido por Pierre Bourdieu que possibilita considerar o conjunto unitário de preferências distintivas (gosto) dos grupos e pessoas como prática social fundamentada na concepção de classe e nas relações de poder em que cada condição de existência condiciona uma estrutura (habitus) estruturada e estruturante e um estilo de vida próprio (BOURDIEU, 2007, p. 163).
} 
Com base nessas reflexões, pode-se afirmar que a gastronomia de um povo constitui expressão simbólica de sua cultura e difere de uma sociedade para outra. A estrutura da gastronomia de um país, de uma região ou mesmo de um grupo étnico apresenta determinadas características comuns que a diferencia das demais com base nos símbolos representativos de sua própria cultura e das possibilidades geográficas e das tecnologias disponíveis em cada lugar, ou seja, há condições objetivas e subjetivas determinantes.

Do ponto de vista da abordagem da gastronomia como elemento representativo da cultura de um grupo social, deve-se considerar, também, os aspectos geográficos que contribuem para definir os sistemas simbólicos de uma cultura. Claval (2007) permite concluir que embora determinados padrões de gosto sejam partilhados igualmente por grupos sociais distintos, os limites geográficos e tecnológicos nos quais se realizam essas manifestações, também, configuram-se como elementos de distinção. Essas práticas estão estreitamente condicionadas ao território onde se vive. Portanto, como destaca o autor, é preciso reconhecer a influência desses elementos na formação das identidades culturais, uma vez que a diversidade cultural resulta "da multiplicidade de combinações produtivas próprias de cada região" (CLAVAL, 2007, p. 278).

\footnotetext{
Nem todas as sociedades dispõem do mesmo arsenal de conhecimentos e técnicas, e do mesmo registro de interpretações e de motivações. Os indivíduos e os grupos são condicionados pela educação que receberam: a cultura aparece, assim, como uma herança. As modalidades segundo as quais a cultura é transmitida de uma geração a outra ou de um lugar a outro, favorecida pelas trocas, pelos deslocamentos de curta duração ou pelas migrações, dependem do meio e do nível técnico; elas contribuem amplamente para a diversidade das sociedades (CLAVAL, 2007, p. 12).
}

Assim, com base nos alimentos oferecidos na infância, da interação social com o meio, das tecnologias disponíveis, a pessoa constrói, simbolicamente, suas preferências alimentares. Cabe assim dizer que a realidade cultural desloca o processo de escolha dos alimentos da esfera individual para o espaço simbólico. Tal percepção reforça o conceito de que o gosto de cada pessoa deriva principalmente do meio social, cultural e geográfico onde ele está inserido, orientando continuamente suas escolhas.

As concepções apresentadas até o momento, dão o tom da abordagem assumida nesta esta pesquisa. Convém enfatizar que o caminho que se percorreu foi traçado tomando-se por base a interpretação da gastronomia como um complexo sistema de códigos culturais histórico-sociais relacionados ao processo de escolha entre o quê, quando e com quem comer, para referenciar Maciel (2005). 
No sentido de aprofundar o pressuposto que se tomou preliminarmente, conclui-se que gastronomia constitui a cultura alimentar que confere identidade a um determinado grupo (ou pessoa) imerso no contexto dos símbolos produzidos por sua própria cultura e, como substância da própria cultura, é vivenciada em um espaço social, transmitida de uma geração a outra e transformada na medida em que as sociedades se transformam.

Tal definição, necessariamente, deve ser acompanhada de um entendimento da gastronomia enquanto fenômeno complexo que abrange dimensões subjetivas e objetivas, conscientes e inconscientes, materiais e simbólicas. De acordo com Morin (2011), a busca do conhecimento requer consciência sobre a complexidade do próprio fenômeno para escapar do paradigma simplificador ou princípio que busca a ordem aparente dos fenômenos a partir de sua redução ou disjunção e conduz a um saber fragmentado, e de sua visão mutiladora. Nesse sentido, o "pensamento complexo é animado por uma tensão permanente entre a aspiração a um saber não fragmentado, não compartimentado, não redutor, e o reconhecimento do inacabado e da incompletude de qualquer conhecimento" (MORIN, 2011, p. 74).

Há que se considerar que a gastronomia é, em grande medida, delineada com base em tradições culturais que são transmitidas de geração em geração. Portanto, entende-se com base nos princípios apontados por Morin (2011) que as pessoas são produtores de um processo de reprodução que lhes é anterior e, ao mesmo tempo, tornam-se produtores do processo que vai continuar. Isso implica dizer que "os indivíduos produzem a sociedade que produz os indivíduos" (MORIN, 2011, p. 74). Desse modo, torna-se relevante pensar os caminhos percorridos para a formação do complexo sistema simbólico híbrido da gastronomia em território brasileiro.

\subsection{A GASTRONOMIA BRASILEIRA: IDENTIDADES CULTURAIS HÍBRIDAS}

Subentende-se que, antes da chegada dos colonizadores, as inúmeras etnias indígenas - especialmente as tribos do tronco tupi - que ocupavam o litoral "conquistado" pelos portugueses detinham ampla e diversificada cultura alimentar baseada na caça, pesca, coleta de frutos nativos e na domesticação de diversas plantas, entre elas a mandioca, conforme Ribeiro (2006). Para o autor, o consumo da mandioca reflete o complexo sistema cultural indígena nativo, pois para o consumo dessa raiz venenosa é necessário o conhecimento e o domínio das técnicas para extração do ácido cianídrico presente em sua composição.

As matrizes indígenas instaladas em solo brasileiro encontravam no consumo da mandioca e de seus derivados suas principais referências alimentares. É importante lembrar 
que esse padrão alimentar com especial destaque para o consumo da mandioca também foi documentado por Pero Vaz de Caminha na Carta a El-Rei Dom Manuel sobre o "achamento" do Brasil:

\begin{abstract}
Eles não lavram, nem criam. Não há aqui boi, nem vaca, nem cabra, nem ovelha, nem galinha, nem qualquer outra alimária, que costumada seja ao viver dos homens. Nem comem senão desse inhame, que aqui há muito, e dessa semente e frutos, que a terra e as árvores de si lançam. E com isto andam tais e tão rijos e tão nédios, que o não somos nós tanto, com quanto trigo e legumes comemos (CAMINHA, 1997, p. 44).
\end{abstract}

A obra de Câmara Cascudo (2004, p. 80) permite concluir que o inhame a que se referia Pero Vaz de Caminha era de fato a mandioca, que na ocasião recebeu por parte dos portugueses o nome inhame, dada a semelhança ao tubérculo conhecido por eles, nativo do continente africano.

De fato, os indígenas autóctones possuíam uma história com o território iniciada há cerca de 12 mil anos e se apresentavam organizados socialmente em inúmeras tribos ${ }^{22}$ com diversidade linguística e cultural (OLIVEIRA; FREIRE, 2006). Del Priore e Venâncio (2001, p. 28) concordam que, no contato com os indígenas, os portugueses ignoraram sua diversidade cultural e religiosa, convencionando-se à imagem de um povo "sem fé, sem lei, sem rei".

É necessário dizer que a expansão ultramarina portuguesa, legitimada e sacralizada pela Igreja Católica, objetivava expandir os domínios econômicos e territoriais da coroa de Portugal "com o fim de carrear para lá toda a riqueza saqueável e, depois, todo o produto da capacidade de produção dos povos conscritos” (RIBEIRO, 2006, p. 35).

Nesses termos, é possível afirmar que as relações de poder entre colonizador e colonizado sintetizam a ideologia vigente no período do Brasil colonial. Com isso, no cerne da relação entre colonizador e colonizado - dominador e dominado - estabeleceu-se o discurso da superioridade racial e cultural por parte dos portugueses. Ribeiro (2006, p. 244) destaca que "a história, na verdade das coisas, se passa nos quadros locais, como eventos que o povo recorda e a seu modo explica". Portanto, pretende-se conduzir uma leitura crítica sobre os múltiplos processos históricos que delinearam a construção de uma identidade nacional calcada em três matrizes culturais.

\footnotetext{
${ }^{22}$ Segundo a pesquisa do etnólogo Curt Nimuendaju apontada por Oliveira; Freire (2011), na época do "descobrimento" existiam no território brasileiro entre 2 e 3 milhões de indígenas distribuídos em cerca de 1400 etnias estruturadas em grandes famílias linguísticas (tupi-guarani, jê, karib, aruák, xirianá, tucano etc.) dispersas geograficamente e com organizações sociais distintas.
} 
Para Ribeiro (2006, p. 40), aos olhos do índio, “a vida era dádiva de deuses bons" e, nesta visão mítica do mundo, o contato inicial com os "recém-chegados" só poderia representar, também, algo positivo. No entanto, o autor lembra que os portugueses trouxeram consigo modelo civilizatório arraigado na cultura do "velho mundo" na qual a "vida era uma tarefa, uma sofrida obrigação, que a todos condenava ao trabalho e tudo subordinava ao lucro". Por essa razão, os portugueses percebiam os índios como "vadios", “inúteis" e "preguiçosos" e, nesse desencontro de visões de mundo e, por conseguinte, da resistência à civilização por parte dos tapuias (inimigos), emerge o conflito, a subjugação, o extermínio e, posteriormente, a escravização, justificados pelo propósito salvacionista e civilizador idealizado para o "novo mundo".

O resultado desse modelo civilizatório constituiu as bases para o desenvolvimento de uma "filial lusitana da civilização europeia", edificando-se nessas terras, uma sociedade estratificada em classes antagônicas, dividida em núcleos urbanos e rurais e integrada à economia mundial na condição de empresa colonial exportadora de açúcar e importadora de bens de consumo e escravos (RIBEIRO, 2006). Em linhas gerais, pode-se afirmar que os engenhos de açúcar do Nordeste formaram as primeiras estruturas político-econômicas da sociedade brasileira. Como destaca Freyre (2006), entre os limites das Casas-Grandes e sob o mando dos senhores de engenho, a cultura da cana-de-açúcar favoreceu o surgimento de uma sociedade aristocrática baseada na monocultura latifundiária e na escravidão.

A partir de 1534, com o início efetivo do empreendimento colonizador — sob o regime das donatarias ${ }^{23}$ — os indígenas passaram a ser escravizados para trabalhar no complexo da indústria açucareira (DEL PRIORE; VENÂNCIO, 2001, p. 35). O açúcar, principal fonte de riqueza comercial do Brasil colonial, demandou, inicialmente, a mão de obra indígena que foi substituída, gradativamente, pela negra, oriunda do comércio de escravos africanos. Para atender o ideal da nova fonte de riqueza da colônia, entre os séculos XVI e meados do XIX, milhares de africanos foram capturados nas terras onde viviam e trazidos ao Brasil para trabalhar nos principais centros de produção açucareira, localizados nos atuais estados de Pernambuco, Bahia e São Paulo, e mais tarde, direcionados para as vilas e cidades para suprir a demanda das minas de ouro e das fazendas de gado.

Por outro lado, muitos desses escravos eram destinados a outros afazeres, como cozinhar para os senhores e suas famílias. Cascudo (2004) afirma que, desde o século XVI, a

\footnotetext{
23 “As donatarias, distribuídas a grandes senhores, agregados ao trono e com fortunas próprias para colonizá-las, constituíram verdadeiras províncias. Eram imensos quinhões com dezenas de léguas encrestadas sobre o mar e penetrando terra adentro até onde topassem com a linha de Tordesilhas" (RIBEIRO, 2006, p. 70).
} 
cozinha dos engenhos era entregue aos negros e, a escrava, independentemente da região de onde era traficada, chegava ao Brasil destinada a trabalhar como cozinheira. Assim, no litoral açucareiro, a cozinha configurou-se como terreno fértil para os primeiros ciclos de hibridação alimentar entre as culturas portuguesa, indígena e africana. Com base nesse aspecto, vale salientar que, diferentemente da ideia de uma gastronomia brasileira harmonicamente miscigenada pela "técnica do negro com ingredientes do índio e receitas do branco", os processos histórico-sociais nos quais se configurou a heterogeneidade que ora se apresenta na gastronomia resultaram, principalmente, do conflito e da necessidade de adaptação.

Reforçando essa visão, Freyre (2006, p. 87) lembra que "cravo, pimenta, âmbar, sândalo, canela, gengibre, marfim, nenhuma substância vegetal ou animal de valor consagrado pelas necessidades e gostos da Europa aristocrática ou burguesa os portugueses encontraram nos trópicos americanos". Pode-se dizer que, ao longo do processo de ocupação do território, os portugueses transplantaram para a colônia suas referências culturais, incluindo os gêneros alimentícios que valorizavam.

A recriação do "cenário gastronômico" desejado pelos portugueses pode ser confirmada na seguinte afirmação de Cascudo (2004, p. 218): “os portugueses foram agentes distribuidores de espécies alimentares com surpreendente eficiência. De suas mais longínquas possessões orientais e africanas traziam sementes, raízes, "mudas", bolbos, confiando-os à terra brasileira". Com efeito, inúmeras espécies animais e vegetais foram aclimatadas e incorporadas definitivamente ao solo e à cultura gastronômica brasileira.

Ao mesmo tempo, ao terem contato com a biodiversidade nativa, os portugueses ampliaram e diversificaram seu repertório alimentar e, acima de tudo, fizeram da farinha de mandioca seu alimento diário, substituindo, sem temor, a farinha do reino ${ }^{24}$ pela goma nativa brasileira nas suas preparações tradicionais e nas criações com as espécies autóctones, segundo os termos apresentados por Cascudo (2004, p. 242). Como lembra o autor, a mandioca foi apontada ainda no século XVII como o universale brasileinsum alimentum. ${ }^{25}$ Por sua vez, conclui que foi no consumo da mandioca e dos seus derivados que se constituiu a base da alimentação brasileira em todas as direções geográficas e que para o brasileiro "comer sem farinha não é comer" (CASCUDO, 2004, p. 101).

\footnotetext{
${ }^{24}$ A farinha-do-reino mencionada por Cascudo (2004) era a farinha de trigo, considerada pela civilização europeia como a mais nobre entre os cereais.

${ }^{25}$ Willem Piso e George Marcgrave escreveram a obra Historia Naturalis Brasilae (1648) considerada um marco descritivo da flora e fauna nativa brasileira. Fornecem um relato completo sobre o processo de produção da farinha e da presença da mandioca na alimentação brasileira da época. Disponível em < http://etnolinguistica.wdfiles.com/local--files/biblio\%3Amarcgrave-1648-

historia/marcgrave_1648_historia.pdf $>$. Acesso em 20. set. 2014.
} 
Por outro lado, Cascudo (2004) deixa claro que "a ciência colonizadora do português atingiu o esplendor na transmissão do seu paladar aos aborígenes e sucessores". Tradicional em Portugal, o gosto pelo doce ${ }^{26}$ acentuou-se ainda mais na colônia açucareira, consagrando o que o autor aponta como a "vitória do açúcar,", pois com as frutas da terra fez-se "marmeladas sem marmelos, pinhoadas sem pinhões e perada sem pêras" (CASCUDO, 2004, p. 241). Para Freyre (2007), em solo brasileiro, em geral, e no Nordeste, em particular, o açúcar possibilitou novos contornos às tradições da doçaria portuguesa e até hoje confere identidade à gastronomia da região.

Nas terras de cana do Brasil essas tradições ganharam sabores tão novos, misturando-se com as frutas dos índios e com os quitutes dos negros, que tomaram uma expressão verdadeiramente brasileira. Não há arte mais autenticamente brasileira que a do doce e a do bolo dos engenhos do Nordeste e do extremo Norte (FREYRE, 2007, p. 66).

Como se vê, além de marcar as relações sociais de poder, o açúcar também delineou os caminhos para a formação das primeiras identidades gastronômicas no Brasil. No entanto, a partir de meados do século XVII, a crise da economia açucareira consolidou nova dinâmica ao território: "a Colônia deu as costas ao litoral e começou a se entranhar nos sertões adentro" (DEL PRIORE; VENÂNCIO, 2001, p. 89). Em busca do ouro, as "bandeiras", constituídas por grupos militarmente organizados, partiram em direção aos chapadões mineiros, goianos e mato-grossenses. Formaram-se novas vilas e cidades que precisaram suprir sua demanda alimentar com uma produção local de gêneros, exploração dos recursos naturais e com o fornecimento regular dos tropeiros. ${ }^{27}$

Segundo Ribeiro (2006, p. 244), esse processo conferiu nova dinâmica social, econômica e cultural ao território "singularizada pelo ajustamento às condições locais, tanto ecológicas quanto de tipos produção". Logo, a atividade mineradora alterou substancialmente a vida e a economia da sociedade colonial. O interior, antes inexplorado, atraiu mais de 300 mil pessoas em apenas sessenta anos para as regiões de Minas Gerais, Goiás e Mato Grosso; entre eles "brancos" vindos do reino e das áreas de ocupação que enfrentavam a crise do

\footnotetext{
${ }^{26}$ É importante dizer que o açúcar ampliou as possibilidades da doçaria e substituiu o papel que o mel cumpria anteriormente o papel de aportar dulçor aos preparos. Como lembra Cascudo (2004, p. 299) era "caro como joia e raro como justiça" e seu uso era símbolo de riqueza e até mesmo poder. Assim, na colônia açucareira esse produto obtido das "sobras" da produção voltada para a exportação era ainda mais valorizado.

${ }^{27}$ Os tropeiros eram comerciantes de produtos e bens, responsáveis, também, por fazer circular sobre o lombo de mulas - até a chegada do trem na segunda metade do século XIX - as informações e as riquezas geradas no interior da colônia. Como destaca Costa (2009), é com o tropeirismo que surgem diversos aglomerados urbanos, fundamentais às próprias tropas (para pouso e abastecimento) e à pecuária muar, que se fazia original mecanismo de circulação territorial.
} 
açúcar e "negros", também, transladados dos engenhos ou trazidos diretamente da África (RIBEIRO, 2006, p. 137).

Ao destacar a importância que a região aurífera teve na articulação social, econômica e política do país, Ribeiro (2006, p. 138) afirma que Minas foi responsável por conectar e integrar as diversas regiões do Brasil. O ciclo do ouro fez florescer cidades ricas e elitizadas que após o esgotamento dos recursos das jazidas, viu sua população se dispersar por toda a região, estabelecendo novas relações interculturais que possibilitaram uma forte identificação cultural com o território.

Já o sertão nordestino, afastado do litoral, serviu, desde o início da colonização como local para criação do gado necessário à subsistência dos núcleos coloniais. No entanto, a própria geografia da região e as contínuas estiagens condicionaram os sertanejos a adaptaremse ao meio para escapar da pobreza como sugere o "cardápio agreste" representado pela paçoca de carne de sol pilada com farinha e rapadura (DEL PRIORE; VENÂNCIO, 2001). Nas regiões com seca menos pronunciada, a pecuária gerou fortunas aos fazendeiros, mas, também, uma dinâmica comercial e social relacionada ao pequeno comércio do gado.

A respeito desse aspecto, Ribeiro (2006) lembra que com a falência das estruturas comerciais baseadas no açúcar e no ouro, a pecuária se estendeu pelos sertões e pelas pastagens sulinas. Da mesma forma, Del Priore; Venâncio (2001) lembram que a criação de gado possibilitou a formação dos primeiros núcleos da "sociedade gaúcha". Num primeiro momento, o gado integrou o modelo ideológico de desenvolvimento econômico e social implementado pelas missões jesuítico-guaranis e depois, após a expulsão da Companhia de Jesus, passou a ser explorado como fonte de riqueza, vinculando o extremo sul ao restante do Brasil, especialmente com a adoção das técnicas de charqueamento que valorizaram os rebanhos para além da venda do couro. Como se vê, os usos e costumes relacionados à atividade pastoril conferiram identidade cultural aos gaúchos.

Ribeiro (2006, p. 304) afirma que a integração da região amazônica "é de fato o maior desafio que o Brasil já enfrentou”. O autor lembra que, de início, portugueses ocuparam a área de floresta na intenção de expulsar franceses, holandeses e ingleses que foram excluídos do Tradado de Tordesilhas (RIBEIRO, 2006, p. 281). Nesse processo, as "drogas da mata" cacau, urucum, sementes, tubérculos, óleos e resinas — adquiriram elevado valor comercial e foram incorporadas ao repertório produtivo da colônia. Foram introduzidos novos núcleos de povoamento na região que permaneceu dependente da população indígena com seus modos de vida que decorriam dos saberes e do domínio sobre a floresta tropical. 


\begin{abstract}
Mais do que transmissores de modos tradicionais de sobrevivência na floresta úmida, desenvolvidos em milênios de esforço adaptativo, os índios foram o saber, o nervo e o músculo dessa sociedade parasitária. Índicos é que fixavam os rumos, remavam as canoas, abriam picadas na mata, descobriam e exploravam as concentrações de especiarias, lavravam a terra e preparavam o alimento. Nenhum colonizador sobreviveria na mata amazônica sem esses índios que eram seus olhos, suas mãos e seus pés. (RIBEIRO, 2006, p. 285)
\end{abstract}

A partir da segunda metade do século XIX, tiveram início as políticas migratórias institucionalizadas pelas quais foi incentivada a vinda de imigrantes estrangeiros para trabalhar como mão de obra livre nas lavouras de café. Para solucionar a carência de trabalho, chegaram ao país um número maior de italianos, alemães, japoneses, entre outros povos. Ao mesmo tempo, dinâmica da imigração subvencionada estimulou a migração de famílias inteiras de mais de uma geração, consolidando, nos locais onde se instalaram esses núcleos familiares, um forte vínculo com as matrizes de origem, formando bolsões culturais que contrastavam as diferenças entre eles e os brasileiros. A análise de Ribeiro (2006) permite concluir que os imigrantes influenciaram comportamentos, culturas e, não parece exaustivo afirmar, a gastronomia, mas esse processo tampouco ocorreu de forma pacífica e homogênea.

Por outro lado, o desembarque massivo dos portugueses — aponta Ribeiro (2006) mudou definitivamente a vida da colônia e da capital a partir do início do século XIX. Além dos 20 mil portugueses que acompanharam a corte portuguesa, instalam-se, no Rio de Janeiro, todos os aparatos burocráticos e culturais do império. Essa nova organização administrativa e social, alterou a paisagem urbana e a rotina dos citadinos ao instituir, oficialmente, os hábitos e gostos da corte que se expressava nas bibliotecas, museus, universidades, bailes, banquetes e até mesmo nos horários das refeições.

No contexto histórico-social da independência, trava-se o rompimento da colônia com Portugal e as províncias se infringem contra o movimento constitucionalista que legitimava a monarquia brasileira, o que resulta em guerras pelo território (DEL PRIORE; VENÂNCIO, 2001). Com isso, institui-se o movimento para construção de uma identidade nacional brasileira liderado pelos intelectuais vinculados ao projeto monárquico unificador em contrapartida aos insurgentes movimentos republicanos separatistas, conforme apontam os mesmos autores. Com o objetivo de contar a história de um Brasil civilizado que se sustentasse não apenas pela influência do colonizador português — do qual os núcleos insurgentes desejavam segregar-se - edifica-se o discurso que reconhece a contribuição do indígena e confirma a existência do negro na nação. Surge assim a "teoria" das três raças que se fundem para formar a raça "brasileira" sob uma nova identidade. 
Com certeza, nos dias de hoje tal definição não seria levada a sério, pois sabemos que a história não é um subproduto das "raças"28. Além disso, do ponto de vista cultural, os mencionados três grupos não formaram unidades homogêneas, nem muito menos mantiveram relações igualitárias no Novo Mundo, como a noção de “fusão" sugere. [...] Talvez a extraordinária repercussão da interpretação adotada pelo IHGB resulte desse pretenso rigor, que encantou não só historiadores, mas também romancistas e poetas (DEL PRIORE; VENÂNCIO, 2001, p. 215).

Referência nos estudos sobre a formação da gastronomia brasileira, Câmara Cascudo dissemina a noção histórica de que "o brasileiro é o herdeiro fiel do patrimônio culinário das três raças formadoras de sua etnia" (2004, p. 478). Em sua "História da Alimentação no Brasil", o autor detalha o "cardápio indígena", a "dieta africana" e a "ementa portuguesa", para afirmar a ideia da miscigenação cultural de indígenas, africanos e portugueses na formação de um novo padrão alimentar "tipicamente brasileiro".

No capítulo dedicado aos imigrantes italianos e alemães, Cascudo (2004) discute superficialmente a influência dessas culturas sobre a gastronomia brasileira. Afirma que alemães rapidamente tornaram-se "brasileiros" na alimentação e pouco contribuíram a não ser pelo "reforço ao consumo de certas espécies utilizadas pelos portugueses desde o século XVI". Por sua vez, descreve que os italianos venceram as circunstâncias da adaptação ao novo território e conseguiram manter a "integridade" de sua alimentação, mas seu patrimônio alimentar, apesar de figurar na alimentação do brasileiro, ficou restrito ao papel de coadjuvante e não se miscigenou na "panela brasileira". Com isso, verifica-se que o autor segue em defesa do discurso ideológico que legitimava o Brasil "cadinho" do período em que pesquisa. $^{29}$

Segundo as ideias apresentadas por Ortiz (2012), é válido dizer que essa formulação encontra plausibilidade em Gilberto Freyre. Ao problematizar sobre o conceito de cultura, Freyre solidificou a mestiçagem no plano simbólico da identidade nacional. Ao mesmo tempo em que ressignifica positivamente as características mestiças da cultura brasileira, a teoria que sintetiza as três culturas numa só, "não somente encobre os conflitos raciais como possibilita a todos de se reconhecerem como nacionais" (ORTIZ, 2012, p. 44).

\footnotetext{
${ }^{28}$ Segundo Del Priore; Venâncio (2001), o esquema que sugere uma identidade brasileira calcada na fusão de três raças foi proposto inicialmente pelo naturalista alemão Karl von Martius ao atender o chamado do Instituto Histórico e Geográfico Brasileiro (IHGB) sobre "como se deve contar a história do Brasil". O instituto, fundado em 1838, reuniu a elite intelectual da época em torno do objetivo de investigar cientificamente e elaborar uma teoria da história do Brasil possível de justificar o propósito unificador do novo Império.

${ }^{29}$ Publicada em 1967, a obra de referência de Luís da Câmara Cascudo sobre a alimentação no Brasil constitui compilação dos apontamentos de vinte anos como o próprio autor destaca na Introdução. Mesmo avançando sobre os conceitos da mestiçagem cultural apresentado por Freyre e transposto para a gastronomia por Cascudo, esses dois autores serão visitados em muitos momentos como fonte de referência histórica e etnográfica da gastronomia brasileira.
} 
De forma análoga, o discurso ideológico sobre a gastronomia brasileira segue calcado nesse amálgama. Basta uma passada pela literatura "gastronômica" atual para encontrar definições como "repleta de influências, a cozinha brasileira se iniciou com a mistura entre as culturas indígenas, portuguesa e africana” (FREIXA; CHAVES, 2009, p. 167). Essas três últimas costumam ser apresentadas separadamente para logo depois, numa visão romanceada da história, surgirem como "gastronomia brasileira". O dilema que se apresenta sobre essa questão está relacionado ao que já se mostrou anteriormente: a tríade índio-negro-branco não representa uma identidade cultural homogênea. Ao mesmo tempo, ao unificar os padrões de gosto, desconsideram-se as estruturas distintivas do habitus e o processo histórico-social de conflitos que se estabeleceram com base nas relações de poder vigentes entre os grupos.

Como se viu, do início da ocupação da costa litorânea ao processo de interiorização do território, a cultura brasileira — e a gastronomia — foi sendo moldada pelas relações sociais entre colonizadores portugueses; indígenas nativos escravizados, dizimados ou integrados ao propósito civilizatório e um terceiro elemento: a mão de obra dos escravos africanos que, desde sua captura e transporte, foram segregados de suas matrizes para restringir as formas de expressão de suas culturas. A respeito desse aspecto, Ribeiro (2006, p. 103) destaca que “iguais na cor e na condição servil, mas diferentes na língua, na identificação tribal e frequentemente hostil pelos referidos conflitos de origem, os negros foram compelidos a incorporar-se passivamente no universo cultural da nova sociedade".

Ribeiro (2006) acredita que nada é tão permanente no Brasil quanto a classe dirigente que, desde os tempos coloniais, implementou instrumentos ideológicos de controle sobre os quais se edificou a sociedade e a cultura brasileira como um modelo da civilização portuguesa. Com base nesse modelo, os núcleos "neobrasileiros" como destaca o autor, não conseguem produzir suas próprias condições de existência e assim tornam-se estratificados e dependentes da metrópole portuguesa.

É certo que a colonização do Brasil se fez como esforço persistente, teimoso, de implantar aqui uma europeidade adaptada nesses trópicos e encarnada nessas mestiçagens. Mas esbarrou sempre, com a resistência birrenta da natureza e com os caprichos da história, que nos fez a nós mesmos, apesar daqueles desígnios, tal qual somos, tão opostos a branquitudes e civilidades, tão interiorizadamente deseuropeus como desíndios e desafros (RIBEIRO, 2006, p. 63).

Ao descrever o processo de "gestação" do povo brasileiro, o autor enfatiza a histórica relação conflituosa entre suas matrizes formadoras. Em solo brasileiro, o encontro entre inúmeras etnias indígenas e africanas com o português revelou desde o início as estruturas sociais do empreendimento colonizador. A essência dessas relações originou os primeiros 
"fillhos da terra" que não se identificavam com portugueses, indígenas ou africanos, isto é, reconheciam suas diferenças em relação a essas matrizes culturais. Começa assim a narrativa de uma "nova" identidade — a do brasileiro — que, pouco a pouco, foi sendo delineada com base no contato entre múltiplas culturas compelidas às relações histórico-sociais vigentes e às particularidades do território e esse encontro não resulta numa síntese, como descreve Machado (2007), mas em identidades culturais híbridas.

Da mesma forma, ao percorrer as ideologias que consagraram a constituição do Brasil como Estado-nação, Costa e Suzuki (2012) lembram que a experiência da colonização aparece como a história forjada pelos próprios colonizadores. Segundo os autores, essa história, unificada e unificadora, contradiz as trajetórias geohistóricas nas quais as rotas de circulação econômica estabeleceram as diferenciações regionais.

[...] no Brasil, a construção do território (bem como sua representação regionalização e regionalismos de gênese) dotado de tessituras sociais produzidas em arquipélagos, pressupondo específicas territorialidades (no escopo das zonas econômicas - antiga zona da mineração, zona do açúcar, amplo território do tabaco, do anil e da cachaça, o trajeto dos tropeiros, a zona das especiarias, dentre outros de menor envergadura) estabeleceu marcos de identidades territoriais e paisagísticas deste universo ibero-americano. As rotas de trânsito, ou seja, fatores da circulação territorial na colônia, estimularam essa mescla de diferenciações regionais [...] (COSTA; SUZUKI, 2012b, p. 5)

Essa referência leva à consideração de que os contínuos fluxos migratórios e os padrões geográficos locais exigem da pesquisa sobre a gastronomia brasileira uma nova lente para sua interpretação, pois o resultado desse multiculturalismo está longe de ser uniforme ou linear e menos ainda ser sintetizado sobre o conceito de uma "gastronomia brasileira" miscigenada, como lembra Dória (2014). Para o autor, “a ideia da miscigenação pode ser muito confortável, mas é um conceito carente de poder explicativo".

\footnotetext{
Nos últimos quinhentos anos travou-se, no território brasileiro, um enorme encontro de culturas - centenas de etnias indígenas; dezenas de etnias africanas transplantadas para cá; portugueses e europeus de outros países - , cujo resultado está longe de ser uniforme ou linear. Marcas da origem disparatada de nossa culinária são visíveis em largas porções do território, ao passo que poucas coisas que realmente a expressam puderam ganhar corpo e se fixar numa síntese (DÓRIA, 2014, p. 17).
}

$\mathrm{Na}$ verdade, a noção de mestiçagem não considera as dinâmicas histórico-sociais no interior das quais se realiza o contato, lembra Ortiz (2012, p. 95). Reconhecendo as contradições existentes nessa narrativa, torna-se oportuno introduzir nesta análise o conceito de hibridação cultural definido por Canclini (2001, p. 14, tradução nossa) como "processos socioculturais nos quais as estruturas ou práticas discretas, que se apresentavam de forma 
separada, se combinam para constituir novas estruturas, objetos e práticas". O autor lembra ainda que nenhuma matriz pode ser considerada uma fonte cultural "pura" ou plenamente homogênea, pois também passou por processos de hibridação.

Assim, considera-se que as culturas tornam-se híbridas com base nos contínuos e ininterruptos ciclos de hibridação às quais foram e são submetidas seja por processos migratórios, fluxos turísticos, intercâmbio econômico ou redes de informação. Essa concepção parece estar mais próxima de um entendimento sobre a gastronomia brasileira, pois cabe ressaltar que os ciclos de hibridação cultural não ocorreram de forma planejada e harmônica de norte a sul do país. Segundo Canclini (2001), o objetivo de interpretar as identidades com base na hibridação consiste na possibilidade de se apreender as relações estabelecidas como consequência dessas mesclas interculturais, pois é certo que nesse processo não ocorre apenas a fusão, mas, sobretudo, a confrontação. Em linhas gerais, a hibridação consiste no conceito que favorece a interpretação da gastronomia brasileira tal como ela se apresenta: plural, diversa, complexa e dinâmica.

Com base nas ideias apresentadas até o momento, considera-se a constante tentativa de associar os códigos simbólicos da gastronomia brasileira a uma das matrizes culturais que a influenciou, uma interpretação cultural limitada e limitadora. Hall (2014, p. 30) lembra que toda a identidade consiste em uma construção simbólica e o sentimento de identificação nacional constitui uma representação ideológica que faz, por exemplo, com que as pessoas se reconheçam brasileiros por partilharem um conjunto de códigos que conferem a eles uma "brasilidade", isto é, um sistema de representações culturais. De forma resumida, seria o mesmo que dizer que para ter um gosto "tipicamente brasileiro" deve-se comer feijoada, tomar caipirinha, gostar de samba e futebol, pois, ao se adotar essas representações ideologicamente construídas no plano simbólico da identidade nacional como "tipicamente brasileiras", além de estigmatizar a diversidade cultural, exclui as diferenças.

Portanto, o sistema nacional de representações culturais que busca unificar todos numa única identidade anula o próprio sentido da identidade. Deve-se lembrar que cada pessoa apreende o símbolo no contexto histórico-social de sua própria cultura e é nesse mesmo contexto que as pessoas constroem sua identidade (MACHADO, 2007). Assim, conclui-se que a identidade é inerente à pessoa e é na diferença em relação ao outro que ele se reconhece como sujeito. No entanto, não se deve perder de vista que essas identidades estão em constante redefinição diante da fluidez das relações sociais vigentes numa sociedade voltada para o consumo. Meneses (2007, p. 19) lembra que "a identidade do indivíduo, hoje, se define de formas múltiplas, no interior da própria subjetividade". 
Da mesma forma, Bauman (2005) e Hall (2014) apontam que a noção de identidade apresenta-se em transformação nos tempos pós-modernos. Se inicialmente foi ancorada na identificação da pessoa a um território ou classe social, hoje, na pós-modernidade, "as identidades ganharam livre curso, e agora cabe a cada pessoa, homem ou mulher, capturá-las em pleno voo, usando seus próprios recursos e ferramentas”(BAUMAN, 2005, p. 35).

Parece seguro afirmar que a gastronomia firma identidades culturais fundamentadas na visão da alteridade em relação ao outro. Como se percebe, a noção de identidade está intimamente relacionada à fronteira imaginada entre "nós" e "eles" e à internalização dos símbolos da cultura à qual se pertence.

Hall (2014) destaca ainda que a transição para o mundo globalizado e a intensa mediação da vida social pelas imagens e símbolos produz nova relação espaço-tempo que desvincula as identidades "de tempos, lugares, histórias e tradições", produzindo o fenômeno da "homogeneização cultural". Em termos práticos, a projeção sobre o "pertencer" a uma cultura ou o "identificar-se com" um grupo cultural que delineava permanentemente a pessoa a uma estrutura de códigos, hoje, na pós-modernidade, torna-se provisória, descentralizada, fragmentada.

Os contínuos fluxos culturais intermediados pelos sistemas de comunicação, viagens internacionais, relações comerciais entre nações e empresas, tendem a homogeneizar as culturas, rompendo definitivamente com o limítrofe distanciamento existente com o outro. Por essa razão, as tradições estão em constante ressignificação no presente, pois só existe tradição se alguma prática for assimilada no contexto atual de dada cultura e ao mesmo tempo seja entendida no contexto histórico-social na qual ela foi produzida.

Assim, “em vez de pensar as culturas nacionais como unificadas, deveríamos pensálas como constituindo um dispositivo discursivo que representa a diferença como unidade ou identidade", propõe Hall (2014, p.36). Isso posto, cabe trazer essa interpretação para a narrativa da gastronomia brasileira, paraense, mineira, gaúcha, etc. Naturalmente, se a ideia de eleger a feijoada como o símbolo que reunia num só preparo o gosto mestiço do brasileiro foi aceito por longo período, com base nessas análises culturais, certamente demonstra-se simplificadora, conforme descreve Morin (2011).

Cabe recorrer novamente aos princípios que Morin (2011) estabeleceu para analisar a complexidade dos fenômenos. Nesse sentido, sob o ponto de vista da complexidade, a gastronomia brasileira passa a ser reconhecida em sua totalidade e a gastronomia paraense o objeto de análise dessa pesquisa - como uma parte desse todo que carrega consigo a quase totalidade do fenômeno representado (MORIN, 2011, p. 74). 
O desafio consiste em proceder uma análise da gastronomia paraense que perpasse os conceitos mutiladores e avance sobre os aspectos que a tornam singular (parte) e, ao mesmo tempo, representativa da gastronomia brasileira (todo). Com isso, pretende-se afastar do discurso a constante tentativa de afirmar que a gastronomia paraense é mais autêntica e original que outras. A gastronomia paraense é a gastronomia brasileira que também é a mineira, a gaúcha, a baiana, etc. 


\section{A INSTITUCIONALIZAÇÃo DA GASTRONOMIA COMO PATRIMÔNIO CULTURAL NO BRASIL}

\subsection{A INSTITUCIONALIZAÇÃO DO PATRIMÔNIO CULTURAL NO BRASIL}

No Brasil, a temática do patrimônio começa a ocupar o pensamento político a partir das primeiras décadas do século $\mathrm{XX}$, quando os intelectuais modernistas elaboraram o arcabouço conceitual das primeiras políticas preservacionistas brasileiras. Rodrigues (1996) destaca que a vanguarda intelectual dos anos 1920 e 1930 fundamenta seu pensamento na valorização das manifestações folclóricas e da arte barroca como elementos constitutivos e representativos das tradições brasileiras passíveis de representar a identidade moderna desejada para (re)contar a história da nação. Como lembra Fonseca (1997, p. 89), Mario de Andrade foi o principal vínculo entre os intelectuais modernistas do país e influenciou a discussão sobre a identidade nacional nas diferentes manifestações artísticas e literárias "através de uma visão crítica do Brasil europeizado e da valorização dos traços primitivos de nossa cultura, até então tidos como sinais de atraso".

Contextualiza-se que, naquele período, o Brasil passava por mudanças significativas em termos econômicos e sociais com o desenvolvimento de uma nova classe de trabalhadores urbanos resultante do acelerado processo de industrialização (ORTIZ, 2012, p. 39). Segundo o mesmo autor, tornava-se necessário superar o pensamento teórico proposto pelos intelectuais do final do século XIX e início do século XX em virtude da nova realidade social que se apresentava. Ortiz (2012) lembra ainda o nítido contorno racista existente no discurso dos precursores das Ciências Sociais brasileiras, pois estes incorporaram em suas análises a doutrina europeizada que se amparava sobre o conceito da evolução histórica dos povos para sustentar o domínio cultural de uma sociedade sobre a outra.

\footnotetext{
$\mathrm{Na}$ verdade, o evolucionismo se propunha a encontrar um nexo entre as diferentes sociedades humanas ao longo da história; aceitando como postulado que o "simples" (povos primitivos) evolui naturalmente para o mais "complexo" (sociedades ocidentais), procurava-se estabelecer as leis que presidiram o progresso das civilizações. Do ponto de vista político, tem-se que o evolucionismo vai possibilitar à elite europeia uma tomada de consciência de seu poderio que se consolida com a expansão mundial do capitalismo. Sem querer reduzi-lo a uma dimensão exclusiva, pode-se dizer que o evolucionismo, em parte, legitima ideologicamente a posição hegemônica do mundo ocidental. A "superioridade" da civilização europeia torna-se assim decorrente de leis naturais que orientariam a história dos povos (ORTIZ, 2012, p. 14).
} 
É necessário um olhar atento sobre o período que compreende as últimas décadas do século XIX e as primeiras do século XX, no qual os historiadores adotaram as teorias evolucionistas para fundamentar suas narrativas a respeito da suposta inferioridade do país em relação ao estágio civilizatório atingido pelos europeus. Com base nesse modelo, os cientistas sociais sustentaram seus argumentos na influência do meio e da raça como elementos deterministas para justificar a problemática da defasagem econômica, social e cultural do Brasil em relação às sociedades europeias e, assim, apreender a realidade e os problemas nacionais (ORTIZ, 2012).

O dilema intelectual da época permanecia sendo o de construir uma identidade nacional diante das contradições históricas que legitimaram e suprimiram as culturas que coexistiam no território nacional. Em suma, na tentativa de elucidar a alteridade entre a cultura colonizadora e a cultura colonizada, os fatores condicionantes naturais (clima, solo, relevo) foram elencados como um dos entraves para a aclimatação da civilização europeia no Brasil e apontado como importante fator para a diferenciação entre ambas as culturas.

Ao mesmo tempo, era latente analisar criticamente a problemática racial, pois, embora o discurso social vigente considerasse indígenas e negros como raças inferiores, havia a necessidade de reconhecer essas matrizes culturais na sociedade. Esses dois elementos meio natural e raça - forneceram os subsídios para consolidar o argumento da miscigenação do povo brasileiro e, por sua vez, legitimou e institucionalizou a superioridade racial do branco na formação da identidade nacional.

Outra importante questão a ser observada diz respeito às políticas imigratórias que, além de suprir diretamente as necessidades econômicas de trabalho no país, atendiam ideologicamente ao propósito de branqueamento da população brasileira (ORTIZ, 2012, p. 32).

Na medida em que a civilização europeia não pode ser transplantada integralmente
para o solo brasileiro (vimos que o meio ambiente é diferente do europeu), na
medida em que no Brasil duas outras raças consideradas inferiores contribuem para
a evolução da história brasileira, torna-se necessário encontrar um ponto de
equilíbrio. Os intelectuais procuram justamente compreender e revelar este nexo que
definiria nossa diferenciação nacional. O mestiço é, para os pensadores do século
XIX, mais do que uma realidade concreta, ele representa uma categoria através da
qual se exprime uma necessidade social - a elaboração de uma identidade nacional.
A mestiçagem, moral e étnica, possibilita a "aclimatação" da civilização europeia
nos trópicos (ORTIZ, 2012, p. 20).

Nesse ponto, o pensamento modernista das décadas de 1920 e 1930 do século XX procura romper definitivamente com a visão romântica estabelecida em fins do século XIX e com as teorias raciais evolucionistas vigentes na virada do século. Para Fonseca (1997), os 
conceitos estéticos, culturais e políticos explicitamente calcados na crítica aos modelos da Velha República delinearam, inclusive, os caminhos para que o grupo modernista assumisse um papel político atuante no recém-criado Serviço do Patrimônio Histórico e Artístico Nacional - SPHAN. ${ }^{30}$

No entanto, observa-se que, mesmo antes da criação do Serviço do Patrimônio Histórico e Artístico Nacional (SPHAN), a preservação do acervo histórico já repercutia nas regiões de passado colonial. Segundo Fonseca (1997), seguia-se a tendência de construir no imaginário coletivo uma nova linguagem estética calcada nas tradições que os modernistas entendiam como "autenticamente" brasileiras mas que demonstrassem a ruptura conceitual e artística proposta pelo movimento. Assim, evocam-se estrategicamente alguns elementos estéticos do passado para construir uma tradição nacional - sem que se perdesse o cunho histórico — no futuro idealizado para a nação.

Rodrigues (1996, p. 195) lembra que o ideal modernista foi consolidado e apresentado, em 1936, no anteprojeto de Mário de Andrade que propunha a criação de um órgão federal voltado para a preservação do patrimônio nacional. O documento, destaca a autora, contemplava visão de vanguarda para a época e se antecipava, inclusive, aos preceitos que foram incorporados posteriormente à noção de patrimônio.

\begin{abstract}
A temática do patrimônio surge, portanto no Brasil, assentada em dois pressupostos do Modernismo, enquanto expressão da modernidade: o caráter ao mesmo tempo universal e particular das autênticas expressões artísticas e a autonomia relativa da esfera cultural em relação às outras esferas da vida social. A atuação dos modernistas no SPHAN vai mostrar como eles puseram em prática, num campo cultural e político específico, e sob um regime autoritário, esses pressupostos (FONSECA, 1997, p. 99).
\end{abstract}

No entanto, nesse mesmo período, o Estado avança sua participação sobre a vida social e passa a invocar as tradições como forma de legitimar o regime político do Estado Novo. Assim, o Decreto-lei $\mathrm{n}^{\mathrm{o}} 25$, de 30 de novembro de 1937, substitui o texto do anteprojeto de Mário de Andrade e institucionaliza o tombamento e a excepcionalidade do bem como instrumento de defesa do interesse público (FONSECA, 1997).

Tratava-se de moldar a cultura brasileira a partir de olhares particulares, seletivos, de objetos portadores da capacidade simbólica de promover a representação nacional e, ao mesmo tempo, de servir de referência para o desenvolvimento de uma estética na qual se refletisse aquilo que uma elite intelectual entendia como retrato síntese do "verdadeiro" Brasil (RODRIGUES, 1996, p. 195).

\footnotetext{
${ }^{30}$ O Serviço do Patrimônio Histórico e Artístico Nacional - SPHAN foi instituído pela Lei $\mathrm{n}^{\text {o. }} 378$, de 13 de janeiro de 1937, dentro da estrutura do Ministério da Educação e Saúde (MES). Em 1970, tornou-se autarquia federal vinculada ao Ministério da Cultura e passou a ser designada Instituto do Patrimônio Histórico e Artístico Nacional (IPHAN).
} 
Segundo Ortiz (2012), sob a influência dos intelectuais da época, a ideologia do Brasil miscigenado pela fusão das três raças — branco, índio e negro — passa a ilustrar o imaginário coletivo e é apropriada pela classe dirigente como alternativa plausível para a construção simbólica de uma identidade nacional capaz de superar definitivamente as mazelas coloniais, consolidar a nova República e projetar o Estado brasileiro na rota do desenvolvimento capitalista. Para o autor, o movimento social e cultural dos modernistas é tomado como referência para um despertar nacionalista à medida que revela a realidade brasileira e permite novas interpretações do espaço social.

Com efeito, Botelho (2006) destaca que no período que se segue da fundação do SPHAN até o final da década de $1960^{31}$ a instituição passou a atender ao interesse ideológico governista e imprimiu uma visão muito particular do passado nacional orientada para o patrimônio arquitetônico que marcava a presença do colonizador português. Em sua análise, Fonseca (1997) também conclui que os aspectos normativos adotados para o tombamento seguiam os valores estéticos dos integrantes do órgão que representavam a elite intelectual, profissional e artística do movimento modernista, isto é, as escolhas e justificativas estavam assentadas na pessoalidade e autoridade que os próprios técnicos representavam.

Na prática, ao atenderem os aspectos da excepcionalidade e estarem vinculados a fatos memoráveis do passado, os bens tombados materializaram a presença do Estado na cultura e passaram a contar a história do Brasil com base em um extrato seletivo da arquitetura do período colonial e imperial (FONSECA, 1997).

Conforme destacam Costa e Suzuki (2012b), "os objetos estéticos da colonização portuguesa na América (materializados nas cidades coloniais), desde sua apresentação, são cultuados sem a carga de dominação que carregaram desde a sua gestação". Com esse entendimento, há que se considerar os elementos contraditórios existentes na produção da identidade nacional que refletem sobremaneira a manifestação do poder e a busca pelo controle social como consequência da soberania territorial (COSTA; SUZUKI, 2012b).

Segundo os mesmos autores, os pilares constitutivos de um projeto nacional começam a ser edificados com base em ruptura entre metrópole (Portugal) e colônia (Brasil). Diante do desafio de conferir unidade territorial, política e econômica ao Estado-Nação, a cultura é cunhada como instrumento de produção da identidade nacional baseada em um recorte caricaturizado do passado colonial.

\footnotetext{
${ }^{31}$ A gestão do SPHAN, desde sua fundação até 1967 (ano de sua aposentadoria), coube a Rodrigo Melo Franco de Andrade, e ficou conhecida como "fase heroica" da instituição.
} 
Mais que indicar uma ideologia espacial em que a nação brasileira deslinda de um território a se unificar materialmente, objetivamos trazer alguns elementos de um período em que o povo e a cultura que o constituía - em sua quase totalidade pouco foram contemplados nesse projeto nacional. A nacionalidade deveria ser inerente não a uma cartografia do território ao qual estariam ligados habitantes desprezados, mas aos membros efetivos desses grupos, aos homens, mulheres e crianças, brancos, pardos, negros ou índios que se considerassem participantes de uma nacionalidade, pois, "como tais, os membros de uma nacionalidade gozariam de 'autonomia cultural'” (COSTA; SUZUKI, 2012b, p. 9).

Em decorrência dos aspectos adotados na política patrimonialista brasileira, o tombamento conferiu à cultura brasileira uma versão muito particular da história, concentrada nos bens materiais e cunhou a expressão do patrimônio em pedra e cal. As políticas preservacionistas brasileiras seguiram essa visão até o início da década de 1970, quando o panorama sobre o patrimônio ganhou novos contornos com a Convenção para Proteção do Patrimônio Mundial, Cultural e Natural, resultado da $17^{\mathrm{a}}$ sessão da Conferência Geral ${ }^{32}$ da Organização das Nações Unidas para Educação, a Ciência e a Cultura (UNESCO).

Para a UNESCO um povo é reconhecido como forte quando mantém seus traços culturais, quando os cultiva e transmite para as novas gerações (CAVALCANTI; FONSECA, 2008). As autoras reforçam os seguintes parâmetros sobre patrimônio cultural imaterial:

\begin{abstract}
As práticas, representações, expressões, conhecimentos e técnicas - junto com os instrumentos, objetos, artefatos e lugares culturais que lhes são associados - que as comunidades, os grupos e, em alguns casos, os indivíduos reconhecem como parte integrante de seu patrimônio cultural. Este patrimônio cultural imaterial, que se transmite de geração em geração, é constantemente recriado pelas comunidades e grupos em função de seu ambiente, de sua interação com a natureza e de sua história, gerando um sentimento de identidade e continuidade e contribuindo assim para promover o respeito à diversidade cultural e à criatividade humana. (CAVALCANTI; FONSECA, 2008, p. 11)
\end{abstract}

Por sua vez, deve-se considerar que as políticas de salvaguarda do patrimônio cultural objetivam documentar o bem e preservar sua memória no sentido de proporcionar aos as condições necessárias para sua continuidade. Com isso, as diretrizes adotadas pelo IPHAN se apresentam em consonância com as novas tendências da política preservacionista mundial e, também, com a institucionalização desses parâmetros no Brasil.

A Constituição Federal de 1988, incluiu os modos de criar, fazer e viver dos grupos formadores da sociedade brasileira no rol do patrimônio cultural brasileiro e assegurou que o

\footnotetext{
${ }^{32}$ Reunida em Paris entre 17/10 e 21/11/1972, a Conferência Geral da UNESCO adota a Convenção para Proteção do Patrimônio Mundial, Cultural e Natural e institui o Comitê do Patrimônio Mundial, órgão colegiado intergovernamental responsável por estabelecer, atualizar e divulgar os bens culturais e naturais de valor universal excepcional sob o rótulo "Lista do Patrimônio Mundial".
} 
estado garantiria e incentivaria a valorização e difusão das manifestações culturais ${ }^{33}$ (BRASIL, 1988). Segundo a Constituição, poder público e comunidade atuam em conjunto na proteção, preservação e gestão do patrimônio histórico e artístico do país que se configura em bens de natureza material e imaterial:

\footnotetext{
Art. 216. Constituem patrimônio cultural brasileiro os bens de natureza material e imaterial, tomados individualmente ou em conjunto, portadores de referência à identidade, à ação, à memória dos diferentes grupos formadores da sociedade brasileira, nos quais se incluem:

I - as formas de expressão;

II - os modos de criar, fazer e viver;

III - as criações científicas, artísticas e tecnológicas;

IV - as obras, objetos, documentos, edificações e demais espaços destinados às manifestações artístico-culturais;

$\mathrm{V}$ - os conjuntos urbanos e sítios de valor histórico, paisagístico, artístico, arqueológico, paleontológico, ecológico e científico. (BRASIL, 1988)
}

Segundo diretrizes do IPHAN, "os bens culturais dizem respeito àquelas práticas e domínios da vida social que se manifestam em saberes, ofícios e modos de fazer; celebrações; formas de expressão cênicas, plásticas, musicais ou lúdicas; e nos lugares". ${ }^{34}$ É interessante pontuar que a gastronomia atende a todos esses requisitos mas ainda são poucas manifestações cultuais gastronômicas registradas. Entre esses registros, cabe um destaque para o "Círio da Nossa Senhora de Nazaré" primeira celebração inscrita no Livro de Registro das Celebrações. ${ }^{35}$

A festa do Círio é uma tradição em Belém do Pará que caracteriza o complexo sistema de uma manifestação cultural híbrida. A celebração compreende o tradicional almoço do Círio, momento em que as famílias se reúnem após a procissão para compartilhar uma refeição que equivale à Ceia de Natal para os paraenses.

Tão logo acaba a procissão, com a chegada da imagem da santa na praça Santuário em frente à Basílica de Nazaré, as famílias dos devotos se reúnem nos lares para uma grande confraternização e também para saborear os deliciosos pratos típicos da cozinha regional paraense, principalmente o pato-no-tucupi e a maniçoba. Essas comidas expressam uma identidade cultural que o paraense faz questão de exibir, especialmente ao visitante que vem de outros lugares, que poderá ser convidado, por alguma família, para participar do almoço. (BRASIL, 2004)

33 Disponível em < http://www.planalto.gov.br/ccivil_03/constituicao/constituicaocompilado.htm>. Acesso em 20. abr. 2015.

${ }^{34}$ Disponível em $<$ http://portal.iphan.gov.br/bcrE/pages/conPatrimonioE.jsf?tipoInformacao=1>. Acesso em 20. abr.2015.

${ }^{35}$ A Festa do Círio de Nossa Senhora de Nazaré em Belém do Pará foi reconhecida como patrimônio cultural brasileiro em 05 de outubro de 2004 por sua relevância como manifestação cultural. Disponível em $<$ Disponível em $<$ http://www.planalto.gov.br/ccivil_03/decreto/D3551.htm>. Acesso em 20. abr.2015. 
Portanto, a celebração do Círio de Nazaré sob a qual o patrimônio cultural foi edificado, confirma nossa posição de que a gastronomia está presente no cotidiano, é vinculada ao território e às condições materiais de existência da cultura que o produz. Ao mesmo tempo em que é "transmitido de geração em geração e constantemente recriado e apropriado por indivíduos e grupos sociais como importante elemento de sua identidade"36.

A partir do percurso estabelecido ao longo desta pesquisa para definir um conceito para a gastronomia que supere o paradigma simplificador, ratifica-se que as manifestações e práticas simbólicas relacionadas à cultura alimentar de um determinado grupo social constituem o patrimônio cultural daquele grupo. Para Rodrigues, as mudanças no contexto cultural refletida nos novos padrões de consumo influenciaram diretamente a percepção sobre o patrimônio, pois tornou os bens culturais mercadorias de fruição para os turistas. A respeito dessa questão, a leitura de Debord (1997) permite considerar que a produção capitalista banalizou os bens patrimonializados ao conferir-lhes publicidade universal e transformá-los em mercadoria espetacular.

Em sua análise, Choay (2001) destaca que a UNESCO consolidou a hierarquização dos valores ocidentais na gestão do patrimônio universal. Segundo a autora, o culto em escala mundial do patrimônio está aliado ao desenvolvimento de uma sociedade consumidora de cultura pelo turismo e, nesse processo, destaca que "a cultura perde seu caráter de realização pessoal, torna-se empresa e logo indústria" (CHOAY, 2001, p. 210).

Com isso, o turismo tende a se apropriar do patrimônio como elemento para motivar a circulação de pessoas tomando-se por base a ressignificação universal dos bens culturais e naturais. É importante compreender que o movimento em torno do patrimônio estabelece nova ordem para a cultura, do entendimento local para o global, da visão particular para a universal.

\subsection{OS (DES)CAMINHOS DO SENTIDO DE PATRIMÔNIO}

De modo geral, qualquer análise sobre patrimônio cultural remete o pensamento à ideia de legitimidade e poder. Nesse ponto, vale considerar a discussão proposta por Bourdieu (1989) sobre a valoração estética que distingue as coisas simples das obras de arte. Para o autor, conferir unicidade a um determinado bem cultural consiste em uma condição do

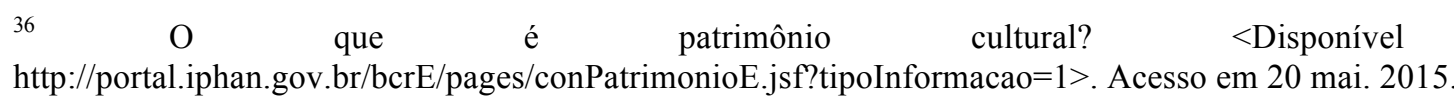

em 
próprio processo histórico no qual se institucionaliza o bem, portanto, oculta e revela as contradições existentes na sociedade.

\begin{abstract}
Ora, esta experiência, no que ela tem aparentemente de mais singular (e esse sentimento de unicidade contribui, sem dúvida, em muito para lhe dar valor), é uma instituição que é produto da invenção histórica e cuja necessidade e razão de ser só podem ser realmente apreendidas mediante uma análise propriamente histórica, a única capaz de explicar ao mesmo tempo a sua natureza e a aparência de universalidade que ela dá àqueles que a vivem ingenuamente (BOURDIEU, 1989, p. 283).
\end{abstract}

Segundo Debord (1997, p.109), o poder dos grupos é continuamente mediado pela própria sociedade na qual se ordenam os fatos, isto é, o passado é ritualizado em tempo comum (que pode ser esquecido) e tempo histórico (que deve ser memorizado), pois, como lembra o autor, "o raciocínio sobre a história é inseparavelmente raciocínio sobre poder". Assim, entende-se que, no tocante às pessoas e grupos que se expressam com base em uma determinada prática cultural, o patrimônio é legitimado no seio da própria cultura.

As raízes do conceito de patrimônio apoiam-se na preocupação em assegurar para as gerações futuras a continuidade do poder de um grupo sobre outro com base na transmissão direta dos bens que foram acumulados num dado processo histórico. Por outro lado, a institucionalização do patrimônio cultural constitui-se como uma prática simbólica de afirmação do habitus, como indica Bourdieu (1989).

Vale refletir que a chancela do patrimônio que recai sobre um determinado bem cultural relega todos os outros que não possuem a mesma notoriedade a uma categoria inferior (TAMASO, 2002). A estruturação desse pensamento corrobora um entendimento, menos simplificador, do processo que fundamenta e atesta as escolhas e exclusões entre o que se deve ou não institucionalizar em nome da identidade nacional ou da relevância cultural para a humanidade.

\footnotetext{
Mais que um testemunho do passado, o patrimônio é um retrato do presente, um registro das possibilidades políticas dos diversos grupos sociais, expressas na apropriação de parte da herança cultural, dos bens que materializam e documentam sua presença no fazer histórico da sociedade (RODRIGUES, 1996, p. 195).
}

A adoção do mecanismo de valoração do patrimônio cultural teve início na França, no século XVIII, quando o Estado iniciou as primeiras medidas para preservar os vestígios do passado e institucionalizou a construção da memória nacional. Após a Revolução Francesa, surge a necessidade da construção da narrativa da identidade nacional que tem como propósito congregar as pessoas que se reconhecem diferentemente, mas se encontram sob os limites de um mesmo território, agora representado por um Estado-nação. Segundo Rodrigues 
(2003), a necessidade de criar um sentimento nacional que ligasse os múltiplos grupos agora denominados franceses - ao território francês — unificado sob novo regime político republicano - consagrou a ideia do patrimônio para contar a história e conferir identidade cultural à nação que se edificava. Nessa perspectiva, o patrimônio cultural passa a representar um conjunto de bens, tradições e costumes que unificavam um determinado território e representavam determinada sociedade (RODRIGUES, 2003).

Parece relevante introduzir nessa reflexão o papel da memória como instrumento de socialização das experiências individuais e sua institucionalização para atender o ideal da construção dos Estados-nação modernos. É necessário compreender os limites entre história e memória, pois, para citar Nora (1993, p. 9), “a memória é um fenômeno sempre atual, um elo vivido no eterno presente; a história, uma representação do passado". O autor observa ainda que a memória espontânea é constantemente manipulada para contar uma história globalizante e explicativa da própria história.

\begin{abstract}
No coração da história trabalha um criticismo destrutor de memória espontânea. A memória é sempre suspeita para a história, cuja verdadeira missão é destruí-la e a repelir. A história é deslegitimação do passado vivido. No horizonte das sociedades de história, nos limites de um mundo completamente historicizado. haveria dessacralização última e definitiva. O movimento da história. A ambição histórica não é a exaltação do que verdadeiramente aconteceu, mas sua anulação. Sem dúvida um criticismo generalizado conservaria museus, medalhas e monumentos, isto é, o arsenal necessário ao seu próprio trabalho, mas esvaziando-os daquilo que. a nosso ver, os faz lugares de memória. Uma sociedade que vivesse integralmente sob o signo da história não conheceria, afinal, mais do que uma sociedade tradicional, lugares onde ancorar sua memória (NORA, 1993, p. 9).
\end{abstract}

De um lado, opera-se a história comum que é suscetível à lembrança e ao esquecimento. De outro lado, materializa-se a história oficial que é transformada em lugares de memória, isto é, espaços simbólicos nos quais os produtores de memórias institucionalizam as lembranças (NORA, 1993). A memória, conclui Menezes (2007), deve ser apreendida como uma ação produtora de significados e valores que serve não apenas como mecanismo de registro e conservação, mas, também, orienta o esquecimento. Dessa forma, a memória coletiva - sobre a qual se constrói o plano simbólico da identidade nacional — não deve ser vista como um somatório de memórias individuais, mas como um esforço articulado para estabelecer coesão aos grupos sociais.

Por sua vez, território se configura como um espaço institucionalizado da memória coletiva. Csergo (1998, p. 811) destaca que no período em que o patrimônio natural e artístico foi inventariado na França, a diversidade gastronômica e o savoir-faire regional foram inscritos simbolicamente na memória coletiva e estabeleceram uma nova articulação entre o 
local e o nacional - as "especialidades alimentares regionais" e a "alta cozinha parisiense" — e entre o particular e o universal - a "cultura provinciana" e a "cultura francesa" - o que reorganizou o passado e conferiu sentido ao presente e ao futuro da nova nação. Assim, as tradições gastronômicas locais passaram a ser rememoradas e associadas ao novo modelo republicano que, ideologicamente, consagrou a diversidade gastronômica regional e o "estar à mesa" como símbolos da identidade nacional francesa (CERGO, 1998, p. 817).

Dessa maneira, fica claro que, após a Revolução Francesa, o processo de construção da memória coletiva que emergiu sob a égide do novo Estado, solidificou o vínculo histórico dos franceses com as singularidades gastronômicas existentes no território. Ao destacar a importância que essas tradições assumem na memória nacional, Cergo (1998, p. 819) lembra que os códigos representativos dessa identidade foram incorporados ao "mesmo plano dos acontecimentos gloriosos do local, do monumento histórico ou da paisagem natural propostos ao turista como merecedores de uma visita, é porque o discurso sobre as cozinhas regionais adquire nessa data uma amplitude considerável".

É importante destacar que, ao serem inscritos na Lista do Patrimônio Mundial, os bens culturais ganham valeur universelle exceptionnelle, conforme Costa; Scarlato (2012). Os autores esclarecem que qualquer nação pode submeter a inscrição dos bens que representam seus patrimônios nacionais para deliberação do Comitê do Patrimônio Mundial. Assim, a chancela que recai sobre o patrimônio cultural homologado por seu valor simbólico "torna-se, cada vez mais, indispensável para lhes atribuir valor de mercado, na perspectiva de recriar um bem especial, irreplicável, em prol do monopólio local” (COSTA; SCARLATO, 2012, p. 119).

Vale dizer que os códigos relacionados à refeição - compartilhados simbolicamente pelos franceses - foram inscritos na Lista Representativa do Patrimônio Cultural Imaterial da Unesco com a rubrica “Le repas gastronomique des Français”. Simbolicamente, consagra-se, na memória coletiva, a aura da "refeição gastronômica dos franceses" como prática simbólica de valor universal excepcional.

Le repas gastronomique des Français ${ }^{37}$ é uma prática social habitual destinada a celebrar os momentos mais importantes da vida dos indivíduos e dos grupos (nascimentos, casamentos, aniversários, conquistas, reuniões. É um momento festivo que reúne pessoas em ocasiões especiais para praticar "a arte de comer e beber bem". Esta prática, muito popular e familiar a todos os franceses, desenvolveu-se na França ao longo dos séculos. Ela é transmitida e está em constante transformação (UNESCO, 2010, tradução nossa).

\footnotetext{
${ }^{37}$ Optou-se por não traduzir o termo "Le repas gastronomique des Français" pois é exatamente seu significado que confere sentido ao termo.
} 
Neste caso, cabe reforçar que o patrimônio chancelado pela Unesco diz respeito "ao momento festivo que reúne pessoas em ocasiões especiais" para comer e beber bem - é importante lembrar que essa valoração deve ser percebida como produzida pela própria cultura francesa. Busca-se com essa informação explicar a tendência equivocada que permeia o "universo gastronômico" na qual a gastronomia francesa é associada a critérios estéticos de distinção e classificação em relação à outras culturas por possuir um valor universal excepcional. Certamente, isso deriva de um contexto histórico-social no qual conjunto de códigos da cultura francesa - e a gastronomia figura nesse conjunto - era (ou ainda é) sinônimo de status e requinte.

Segundo Costa (2011, p. 31), o prestígio internacional dado aos bens inscritos na Lista do Patrimônio Mundial deve ser apreendido sob o conceito da patrimonialização global definido pelo autor como "o brusco movimento universal de espetacularização e banalização pela cenarização progressiva dos lugares promovido pela dialética Estado-mercado, sobre a base das técnicas, da ciência e da informação. É um processo de ressignificação dos lugares em escala planetária". Essa reflexão permite identificar a dialética existente no processo de patrimonialização que recria, objetiva e subjetivamente, as singularidades e os lugares de memória.

No contexto atual, ao se considerar que as sociedades vivem da produção e consumo de símbolos e imagens, conforme os termos propostos por Debord (1997), torna-se indispensável manter e alimentar essa dinâmica por meio da contínua acumulação de espetáculos. Com esse pressuposto, toda sociedade inserida na produção moderna torna-se apenas uma representação dela mesma, na qual as relações sociais são mediadas pelos símbolos que são ao mesmo tempo o sentido e a finalidade dessa produção.

O conceito de espetáculo unifica e explica uma grande diversidade de fenômenos
aparentes. As suas diversidades e contrastes são as aparências organizadas
socialmente, que devem, elas própria, serem reconhecidas na sua verdade geral.
Considerado segundo os seus próprios termos, o espetáculo é a afirmação da
aparência e a afirmação de toda a vida humana, socialmente falando, como simples
aparência. Mas a crítica que atinge a verdade do espetáculo descobre-o como a
negação da vida que se tornou visível (DEBORD, 1997, p. 16).

Gastal (2005, p.16) reconhece que, numa sociedade consumidora de espetáculos, qualquer reflexão sobre o turismo deve considerar a íntima relação entre o imaginário e a imagem dos lugares. A autora afirma que "produzir e consumir imaginários passou a fazer parte das necessidades básicas humanas" (GASTAL, 2005, p. 69). 
Os tempos pós-modernos contemporâneos nos defrontam com novas necessidades e novos desejos: vivemos na era do consumo, quando compramos não mais para atender apenas às nossas necessidades, mas também para atender aos nossos desejos transformados em necessidades. E os produtos pós-modernos não vendem apenas a si mesmos, precisam agregar imaginários porque os novos clientes necessitam dos dois: do objeto e do imaginário, sendo que o imaginário, como já colocado, pode ter valor de mercado muito superior ao objeto em si. Para vender esses produtos que somam imaginários aos objetos, a produção se aproxima dos meios de comunicação. (GASTAL, 2005, p. 69)

Como se vê, essa citação revela a dinâmica existente entre produção e consumo dos bens culturais. Na medida em que gastronomia paraense é entendida como importante atrativo turístico com vistas ao desenvolvimento econômico e social do estado, surge o interesse em agregar novos valores que atendam aos padrões de gosto vigentes na sociedade.

\footnotetext{
Essa será uma das grandes marcas do momento pós-moderno, pois iguala todos os produtos colocados no mercado, com destaque para os produtos culturais - aí incluído o turismo -, com exigências para além das pertinentes ao seu uso ou desfrute, pois a eles deve ser agregado um padrão estético de qualidade: eles devem ser belos ao gosto contemporâneo. Isso vale para roupas, para a arquitetura, para a decoração de restaurantes, design de aviões, para o traçado urbano, para objetos em exposição num museu ou para rostos e corpos. (GASTAL, 2005, p. 29)
}

Desse modo, a gastronomia paraense passa a compor o argumento da oferta turística do estado e mobilizar esforços dos agentes públicos e privados para ampliar sua renda em virtude das "qualidades especiais" e exclusividade do bem (HARVEY, 2005). Resultante de contínuos processos de hibridação cultural delineados, inclusive, pelos padrões geográficos configurados pela biodiversidade endêmica, as formas singulares de expressão da gastronomia paraense começaram a ser deslocadas do local para o global.

Esse fato pode ser observado com o notório destaque que "produtos gastronômicos do Pará" recebem de conceituados chefs de cozinha que, por sua vez, se destacam nacional e internacionalmente na medida em que incorporaram essas referências em suas criações gastronômicas. A crítica que se faz sobre a apropriação material e simbólica de alguns elementos do patrimônio cultural e da identidade gastronômica paraense consiste na tendência de promover essa gastronomia como atrativo turístico para atender a lógica da acumulação capitalista. 


\section{A VALORAÇÃO E A VALORIZAÇÃO DA GASTRONOMIA EM BELÉM DO PARÁ}

\subsection{A INSTITUCIONALIZAÇÃO DA GASTRONOMIA COMO ATRATIVO TURÍSTICO}

Turismo e gastronomia apresentam-se intimamente relacionados. Numa visão geral, a gastronomia pode ser vista apenas como uma oferta de serviço aos turistas ou, sob um olhar mais atento, integrar o conjunto de atrativos culturais que motivam uma viagem. O "exótico", isto é, a cultura do outro, atrai o "olhar do turista" tomando-se por base os signos e padrões sociais vigentes e varia de acordo com o período histórico e a própria sociedade (URRY, 2001).

Com base no discurso de Urry (2001), considera-se que a gastronomia - ao mesmo tempo em que representa uns e diferencia outros - ao ser considerada "exótica" passa a despertar o interesse e a curiosidade do "olhar do turista". Portanto, os aspectos intrínsecos ao "olhar do turista" captam o extraordinário, isto é, aquilo que se situa fora de sua rotina. Diante disso, o autor lembra que o "olhar do turista" é provocado a encarar e consumir um conjunto de experiências, em suma, desnecessárias na expectativa de vivenciar momentos distintos daqueles baseados nas rotinas e práticas do cotidiano do trabalho e da moradia.

Sabe-se que turistas percorrem o mundo em busca da diversidade cultural e, nos últimos anos, a gastronomia assumiu um papel relevante entre os atrativos dos destinos capazes de motivar e deslocar o "olhar do turista". Schlütler (2003, p. 9) lembra que "o turismo tem sua raiz nas diferentes manifestações patrimoniais, sejam elas naturais ou culturais". A autora complementa dizendo que os aspectos tradicionais da cultura - entre os quais inclui a gastronomia - por conterem significados simbólicos fazem parte do consumo turístico.

Consoante Moesch (2000), entende-se o turismo como um fenômeno social com dimensões objetivas e subjetivas que resultam da combinação complexa de interrelacionamentos entre produção e serviços. Segundo a autora, a complexidade conduz à compreensão de que o fenômeno turístico apresenta-se como um processo inseparável e interdependente entre os objetos de consumo do turismo e os turistas que os consomem (MOESCH, 2004).

Volta-se novamente o pensamento a Morin (2011) sob o qual Moesch (2004) discorre a respeito da complexidade do fenômeno turístico para a construção de uma epistemologia 
social do turismo que perpasse a leitura superficial vigente em direção a um pensamento crítico não simplificador.

[...] O Turismo é produzido pelas interações entre os sujeitos que o constituem: os turistas, produtores e reprodutores do sistema, comunidade local. O Turismo mesmo, como um todo organizado e organizador, retroatua para reproduzir mediante a economia, a comunicação, o imaginário, a diversão, a tecnologia, o tempo, o espaço, as vivências sociais e culturais que o nômade pós-moderno (o errante) procura. Assim, é que os turistas, em suas intenções, produzem o Turismo, o qual produz os turistas que o produzem. Isso se sucede num circuito espiralado, através da evolução da história do Turismo. Esta compreensão da complexidade turística requer uma mudança muito profunda de nossas estruturas mentais. Corremos o risco de isso não ocorrer o que geraria uma grande confusão e negação dos problemas epistemológicos propostos (MOESCH, 2004, p. 408).

Com base nos entendimentos de Debord (1997) e Urry (2011), admite-se que o objeto do "olhar do turista" é motivado pelos padrões de diferenciação e legitimação estabelecidos na sociedade e constantemente estimulado pelos símbolos "dignos" de serem vistos no contexto de uma sociedade alienada consumidora de espetáculos colecionáveis.

[...] conjunto de atividades sociais preferidas, altamente estruturadas por distinções de gosto. Tais práticas levam as pessoas a querer estar em determinados lugares, contemplando determinados objetos, na companhia de outros tipos específicos de pessoas. De outro lado, uma ampla variedade de serviços, sobretudo sob condições de maximização dos lucros, é fornecida para turistas como estes. Conforme vimos, grandes indústrias internacionais se desenvolveram e elas podem proporcionar serviços a um custo que possibilita o desenvolvimento de grandes mercados segmentados (URRY, 2001, p. 96).

É com base nesses aspectos, que a gastronomia emerge como componente da oferta turística dos destinos. Portanto, pode-se afirmar que a gastronomia, em virtude dos apontamentos propostos nesta dissertação, figura como uma das práticas culturais associadas ao turismo "altamente estruturadas por distinções de gosto" entre as quais observa-se um crescente interesse em sua promoção.

Reconhecendo-se essa abordagem e as discussões estabelecidas anteriormente, convém reforçar que as relações entre turismo e gastronomia ultrapassam aquelas que provem exclusivamente da oferta de serviços de alimentação para satisfazer as necessidades biológicas dos turistas. No momento em que a gastronomia passa a ser importante elemento de distinção e afirmação dos estilos de vida, todo o conjunto material e simbólico associado à ela assume um valor de mercado.

Não obstante, Bourdieu (1989) destaca que o habitus condiciona as escolhas numa complexa relação de interdependência entre os grupos sociais e os indivíduos que constroem suas identidades nesses grupos. Portanto, é seguro afirmar que o "olhar do turista" é 
constantemente influenciado por listas e rankings que chancelam e classificam os melhores restaurantes para se comer ao redor do mundo, os principais destinos gastronômicos a se visitar ou as culturas a serem "consumidas" para vivenciar uma experiência gastronômica "autêntica" e "original". Ao mesmo tempo, essa dinâmica encoraja os agentes públicos e privados a apresentar e estruturar o patrimônio gastronômico local como atrativo turístico. Promover os preparos, ingredientes, técnicas, saberes e fazeres tradicionais, isto é, o patrimônio gastronômico de um destino passa a ter cada vez mais importância como diferencial competitivo no turismo de uma região.

Um exemplo disso é a prestigiada lista The World's 50 ${ }^{\text {th }}$ Best Restaurants que chancela os melhores restaurantes ao redor do mundo e insere alguns destinos no "mapa" turístico a partir de sua gastronomia. O mesmo pode ser percebido com alguns prêmios internacionais como de "Melhor Destino Culinário do Mundo" promovido pela World Travel Awards (WTA) e que desde 2013 é conquistado pelo Peru. Na perspectiva de Costa; Scarlato (2012), essas listas e prêmios reverberam o momento em que as culturas são ressignificadas e apropriadas para atender a lógica da acumulação capitalista.

Cabe aqui uma breve contextualização sobre as diretrizes do planejamento turístico brasileiro definidas a partir da criação do Ministério do Turismo como pasta autônoma e independente. Observa-se, desde os primeiros instrumentos técnicos de planejamento consolidados pelo Plano Nacional de Turismo ${ }^{38}$, a preocupação em fortalecer o modelo da gestão descentralizada do turismo por meio das diversas instâncias de governança local, regional e nacional e da participação dos agentes públicos e privados.

Desde a criação do Ministério do Turismo e da reativação do Conselho Nacional de Turismo, em 2003, a atividade nessa área vem ganhando o devido reconhecimento como um importante vetor de desenvolvimento socioeconômico. Institucionalmente, isso se reflete na credibilidade que o Ministério do Turismo tem obtido na formulação e na implementação das políticas para o setor, em um processo aberto e democrático decorrente da proposta de gestão descentralizada. A elaboração do Plano Nacional de Turismo, nas edições de 2003-2007 e 2007-2010, contou com a ampla participação dos segmentos representativos que integram o Sistema Nacional de Turismo, segundo um formato de trabalho conjunto que privilegiou momentos de reflexão, no Ministério do Turismo e no Conselho Nacional de Turismo, sobre as perspectivas e proposições para o desenvolvimento da atividade (BRASIL, 2013, p. 43).

Percebe-se no caso brasileiro que o documento orienta as ações da política de turismo e afirma representatividade dos atores (públicos e privados) em prol do desenvolvimento

\footnotetext{
${ }^{38}$ A primeira edição do Plano Nacional de Turismo 2003-2006 propõe o modelo de gestão descentralizada do turismo e destaca o Conselho Nacional do Turismo e os Fóruns Estaduais como interlocutores estratégicos para o atendimento às necessidades dos destinos turísticos brasileiros (BRASIL, 2003b).
} 
turístico dos destinos brasileiros. Parece relevante dizer que a Constituição Federal de $1988^{39}$ indica no Artigo 180 que turismo deve ser incentivado pela União, estados, Distrito Federal e municípios como fator de desenvolvimento econômico e social. Por sua vez, é a Lei do Turismo $^{40}$ que institui o modelo de gestão participativo no planejamento turístico amparado no Sistema Nacional do Turismo sob os "princípios da publicidade, da transparência e do controle social como direcionadores estratégicos imprescindíveis para o amadurecimento do setor turístico brasileiro". 41

O Plano Nacional de Turismo 2003-2007 estabelece que além de difundir a "imagem de país moderno, com credibilidade e com produtos de qualidade", a política de turismo deve promover de maneira integrada a "essência brasileira, sua cultura, sua diversidade étnica, social e as diferentes regiões do país" (BRASIL, 2003b, p. 25).

A promoção do turismo brasileiro no mercado internacional terá como conceito
estratégico a diversificação de imagem do país. As ações de promoção e marketing
irão orientar a construção do Brasil como destino turístico de um país moderno, com
credibilidade, alegre, jovem, hospitaleiro, capaz de proporcionar lazer de qualidade,
novas experiências aos visitantes, realizar negócios, eventos e incentivos e ser
competitivo internacionalmente. Os programas de promoção e marketing terão como
essência a qualidade e a diversidade da produção cultural brasileira, além de nossa
diversidade étnica, social e natural (BRASIL, 2003b, p. 42).

Com o propósito de conduzir as recomendações estratégicas do plano, a promoção turística do Brasil foi estruturada tomando-se por base dois públicos-alvo distintos: o nacional e o internacional. Dessa forma, "propor, apoiar, planejar, coordenar e acompanhar as ações e projetos de marketing, promocional e institucional, propaganda e divulgação do turismo brasileiro no mercado nacional" ficou a cargo do Departamento de Marketing Nacional, vinculado à Secretaria Nacional de Políticas de Turismo ${ }^{42}$.

\footnotetext{
${ }^{39}$ Art. 180. A União, os Estados, o Distrito Federal e os Municípios promoverão e incentivarão o turismo como fator de desenvolvimento social e econômico (BRASIL, 1988).

${ }^{40}$ A Lei 11.771 de 17 de setembro de 2008 dispõe sobre a Política Nacional de Turismo, define as atribuições do Governo Federal no planejamento, desenvolvimento e estímulo ao setor turístico a partir do Plano Nacional do Turismo (PNT) e institui o Sistema Nacional do Turismo composto pelo Ministério do Turismo, Embratur, Conselho Nacional de Turismo, Fórum Nacional dos Secretários e Dirigentes Estaduais de Turismo além de incluir as instâncias de governança macrorregionais, regionais e estaduais, os fóruns e conselhos estaduais e os órgãos estaduais de turismo.

41 Plano Nacional do Turismo 2013-2016. Disponível em: $<$ http://www.turismo.gov.br/export/sites/default/turismo/ o_ministerio/publicacoes/downloads_publicacoes/plano_nacional_2013.pdf>. Acesso em: 01 mai. 2015.

${ }^{42}$ Informações constantes no Regimento Interno do Ministério do Turismo ${ }^{42}$. Disponível em: $<$ http://www.turismo.gov.br/export/sites/default/turismo/o_ministerio/regimento/download regimento/decreto_8102_2013.pdf>. Acesso em: 01 mai. 2015.
} 
Por outro lado, a promoção turística internacional passou a ser realizada exclusivamente pela Embratur (Instituto Brasileiro de Turismo) ${ }^{43}$ uma vez que "essa mudança de foco requeria da autarquia uma atuação profissional e direcionada a atender as necessidades e os desejos do mercado internacional”.

Para que o turismo no Brasil adquirisse a importância necessária, foi feita uma
mudança formal importante que deve ser percebida por todos os públicos. Com esta
finalidade o Programa de Identidade Turística incluiu o desenho da marca, o
decálogo, a mensagem permanente e a normalização dos mesmos, assim como a
preparação de um banco de imagens próprio para a nova imagem que pretende-se
implantar (BRASIL, 2007, p. 1).

Destaca-se ainda que a Embratur "recebeu a missão de executar a promoção, marketing e apoio a comercialização dos destinos, serviços e produtos turísticos brasileiros no mercado internacional, de acordo com as metas estabelecidas pelo Plano Nacional de Turismo" (BRASIL, 2009, p. 63). Com isso, evidencia-se a presença pública na alocação de recursos e nos esforços para aumentar o número de turistas estrangeiros que visitam o país frente a um mercado turístico competitivo de abrangência internacional.

Acredita-se que é nesse momento que desponta o interesse em (re)posicionar o país enquanto destino turístico para atender as demandas dos turistas consumidores de espetáculos em nível internacional. É possível identificar um reflexo dessas estratégia no Plano Aquarela 2020 - Marketing Turístico Internacional do Brasil ${ }^{44}$, o enfoque dado à diversidade natural e cultural como um dos elementos intrínsecos à imagem do país. O destino Brasil é trabalhado como marca guarda-chuva na promoção internacional do país, isto é, as ações estratégicas são voltadas para a consolidação do Brasil como um dos destinos líderes do turismo mundial até 2020 (BRASIL, 2009).

É importante considerar que o processo de construção dessa imagem foi iniciado durante as etapas de pesquisas do planejamento de marketing do destino aplicadas a turistas e profissionais do setor de turismo ${ }^{45}$. Certamente, as diretrizes, estratégias e ações promocionais bem como a estruturação da política pública de turismo foram validadas segundo pesquisas

\footnotetext{
${ }^{43}$ A EMBRATUR foi criada pelo Decreto-Lei $N^{\circ} 55$ de 18 de novembro de 1966 juntamente com o Conselho Nacional de Turismo. Inicialmente, a denominada Empresa Brasileira de Turismo era vinculada ao Ministério da Indústria e Comércio e ocupava-se da execução das diretrizes nacionais estabelecidas pelo governo para desenvolvimento da indústria do turismo. A Lei $\mathrm{N}^{\mathrm{o}}$ 8.181, de 28 de marco de 1981, revogou o Decreto e conferiu à Embratur a denominação de Instituto Brasileiro de Turismo com a finalidade de apoiar a formulação e coordenar a implementação da política nacional do turismo, como fator de desenvolvimento social e econômico do país. Em 2003, a Embratur passou a cuidar da promoção turística internacional.

${ }^{44}$ Documento estratégico que orienta e norteia a promoção internacional do Destino Brasil (BRASIL, 2009).

${ }^{45}$ Informações retiradas do Plano Aquarela 2003 que elenca os resultados da pesquisa sobre a imagem do Brasil a partir da opinião de turistas, operadores internacionais e do setor produtivo do turismo nacional. (BRASIL, 2003a)
} 
realizadas com o intuito de decodificar a imagem do Brasil perceptível ao complexo olhar do turista. Considera-se relevante que os resultados das pesquisas apresentadas no Plano Aquarela 2005-2009 (BRASIL, 2009, p. 71) definem a formulação das estratégias da oferta turística brasileira àquilo que o turista estava predisposto a ver.

Consolidada a etapa de diagnóstico, foram geradas as seguintes informações sobre a imagem e o imaginário do destino Brasil (BRASIL 2009, p. 71):

os turistas internacionais que visitavam o Brasil eram experientes, haviam feito pelo menos uma viagem intercontinental nos últimos dois anos.

o índice de repetição da viagem ao Brasil era bastante alto, ou seja, esses turistas estavam sendo fidelizados.

os principais motivos da escolha do país como destino turístico apontados foram, em ordem de prioridade: sol e praia; conhecer o Brasil; belezas naturais; cultura viva; povo; recomendação de amigos e parentes.

o melhor do Brasil é a natureza e o povo. Dentre os aspectos negativos destacados estavam a pobreza e a segurança pública.

o interesse pelo Brasil entre os turistas potenciais era alto, mas a predisposição para viajar em curto e médio prazo era pequena.

a opinião interna destacou como síntese do Brasil a diversidade e a possibilidade de vivenciar novas e diferentes culturas e ambientes.

entre os pontos fortes do Brasil destacaram-se: os atrativos naturais, a diversidade cultural, o povo brasileiro e a imagem do Brasil.

os ícones do país apontados foram Rio de Janeiro, Amazônia, Povo Brasileiro, Diversidade, Foz do Iguaçu e Brasília.

o nível de conhecimento dos turistas potenciais e dos profissionais do setor de turismo no exterior em relação ao país era muito baixo. Mesmo para o turista que já havia estado no Brasil, o conhecimento era concentrado nos ícones e havia insegurança sobre a infraestrutura do país. Portanto, o grande desafio da comunicação naquele momento seria fazer que tais públicos descobrissem de fato o Brasil.

o mapeamento do posicionamento do destino Brasil para os diferentes merca- dos revelou que havia um consenso no imaginário dos diferentes públicos. $\mathrm{O}$ posicionamento do Brasil estava sempre entre natureza/patrimônio natural e estilo de vida.

Tal direcionamento reforça a condição em que o olhar do turista passa a ser disputado num mercado altamente competitivo por um prisma econômico e condicionado ao contexto histórico no qual as práticas sociais afirmam, segundo Urry (2001, p. 17), que "ser turista" é uma das características da experiência "moderna". Identificam-se que esses resultados atuam como subsídios para a promoção turística internacional da diversidade cultural brasileira. A 
metodologia para comunicação estratégica do Brasil foi construída sob um conjunto de argumentos e valores capazes de sintetizar o posicionamento desejado no mercado internacional, isto é, figurar entre os destinos líderes do turismo mundial. Os princípios norteadores encontram-se reunidos no Decálogo Geral do Brasil (Figura 4) e fundamentam-se em cinco categorias: natureza, cultura viva, povo, clima e modernidade.

Figura 4 - Decálogo Geral do Brasil

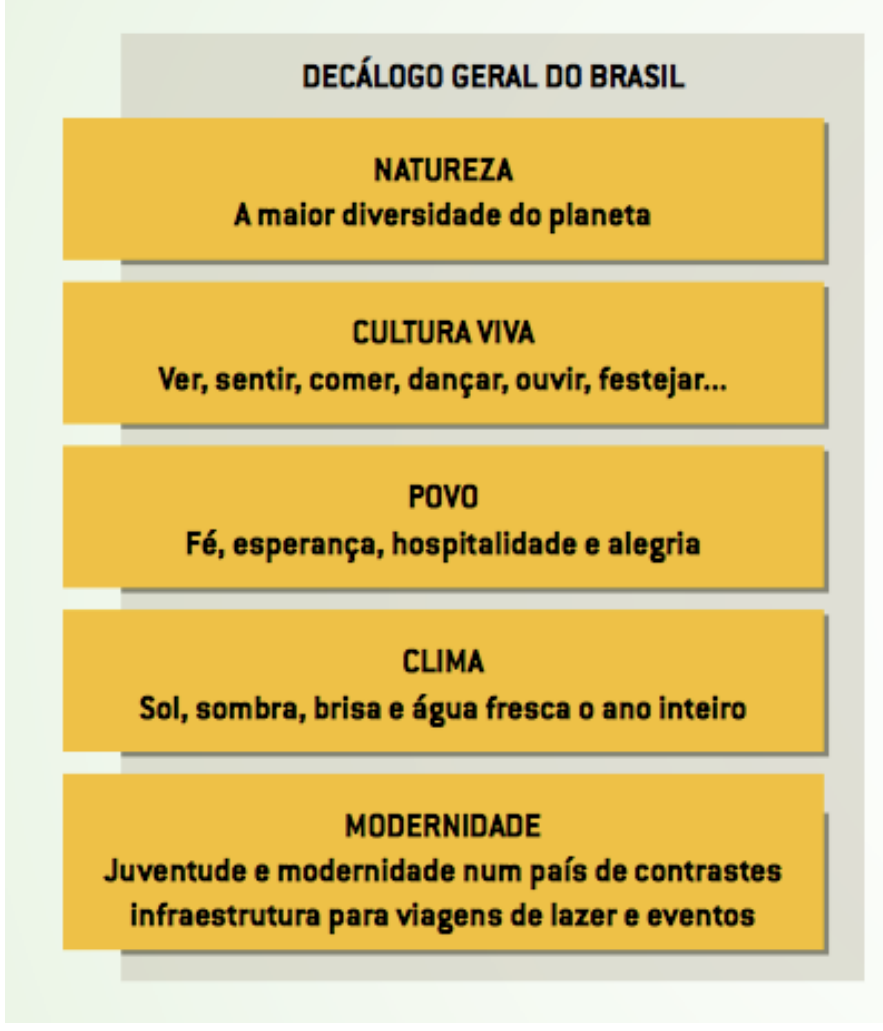

Fonte: Plano Aquarela 2003-2009 (Embratur)

Um dos objetivos gerais apontados pelo Plano Nacional de Turismo 2007-2010 consiste em "desenvolver o produto turístico brasileiro com qualidade, contemplando nossas diversidades regionais, culturais e naturais" (BRASIL, 2007, p. 16). Ao mesmo tempo, incorpora ações de sensibilização entre os diversos atores do turismo para as perspectivas de desenvolvimento socioeconômico nas diferentes regiões do país como consequência da expansão da atividade turística organizada e qualificada, envolvendo o poder público nas três esferas de governo, a iniciativa privada e o terceiro setor.

O discurso da excelência e o estímulo ao desenvolvimento de novos produtos turísticos pode ser identificado no trecho a seguir: 
Ainda no âmbito da qualificação de novos produtos turísticos, deve ser fomentada e valorizada a produção associada ao turismo, possibilitando o desenvolvimento de atributos que fortaleçam os aspectos naturais, culturais e sociais dos destinos turísticos. Como resultado, ocorre a dinamização econômica das comunidades locais, com a geração de renda e trabalho e com a distribuição dos benefícios gerados pelo turismo. É importante salientar que dos produtos associados ao turismo ressurgem, entre outros, as artes, as crenças, os cerimoniais, a linguagem, a moda e o patrimônio arquitetônico, que são restituídos ao cotidiano, transformados em atrativos típicos e em roteiros de sabores e fazeres (BRASIL, 2007, p. 27).

Por sua vez, o Plano Nacional do Turismo reconhece o espaço territorial entre as estratégias para desenvolvimento do turismo em todas as regiões do Brasil. Com o objetivo de atingir as metas propostas, aponta alguns eixos de intervenção entre os quais destaca a "oferta de novos produtos, contemplando nossa diversidade cultural e regional (BRASIL, 2003b, p. 29). Sob o enfoque da ampliação da oferta turística o referido plano destaca que "os produtos atualmente ofertados não contemplam a pluralidade cultural e a diversidade regional brasileira. Existe um potencial a ser revelado e trabalhado no interior do país, e uma urgente necessidade de encontrar alternativas de desenvolvimento local e regional" (BRASIL, 2003b, p. 31).

Como parte da política estratégica que norteia o desenvolvimento turístico no país, a regionalização é resultado de um processo de planejamento descentralizado e compartilhado, iniciado em 2003, que resultou na estruturação e na implementação de instrumentos e de ferramentas que têm permitido maior interlocução do Ministério do Turismo com as 27 Unidades Federativas do país. Assim, como resultado da ação integrada que tem evoluído ao longo de 2003-2012, o mapa turístico brasileiro conta atualmente com 3.635 municípios, organizados em 276 regiões turísticas. A avaliação recente do Programa de Regionalização aponta para a necessidade de novos desafios, notadamente no que diz respeito à construção de uma estratégia de fortalecimento e posicionamento do turismo a partir da organização das regiões com abordagem territorial e institucional para o desenvolvimento e a integração do turismo no Brasil (BRASIL, 2003b, p. 56).

$\mathrm{Na}$ perspectiva de desconcentrar a oferta turística brasileira do litoral para o interior, o Ministério do Turismo instituiu, em 2004, o Programa Nacional de Regionalização do Turismo - Roteiros do Brasil. O programa propõe a expansão da atividade turística para as diferentes regiões do país no sentido de ampliar e mostrar as potencialidades ao mercado interno e externo. Como estratégia para impulsionar as ações de regionalização, as diretrizes do programa passaram a ser apresentadas e trabalhadas no Salão do Turismo - Roteiros do Brasil. ${ }^{46}$ Com isso, identificou-se a necessidade de reorganizar a oferta turística nacional com a seleção e desenvolvimento de novos roteiros turísticos "para serem trabalhados com o objetivo de alcançar o padrão internacional de qualidade” (BRASIL, 2007, p. 25).

\footnotetext{
${ }^{46}$ O Salão do Turismo - Roteiros do Brasil foi criado pelo Ministério do Turismo para impulsionar as ações da regionalizaçã e a primeira edição do evento, realizada em 2005, apresentou ao mercado nacional 401 roteiros turísticos, envolvendo 909 municípios em 134 regiões turísticas (BRASIL, 2007, p. 25).
} 
Com base nas diretrizes de diversificação e desenvolvimento da atividade turística no Brasil e dos elementos da promoção turística internacional pontuados na série histórica do Plano Aquarela da Embratur, evidencia-se o encadeamento das iniciativas de valorização das expressões culturais brasileiras, entre elas, a gastronomia, nas ações promocionais públicas de turismo nas esferas federal, estadual e municipal.

Nos últimos anos, a tendência de incorporar a gastronomia como atrativo cultural ganhou relevância no país ao ser associada ao produto "Brasil" e exemplo disso consiste em um conjunto de ações promovidos pela Embratur ao lado de chefs de cozinha brasileiros para intensificar a promoção turística do país no exterior por meio dos seus atrativos gastronômicos. A autarquia estruturou uma série de ações que visam promover a gastronomia brasileira no exterior e incentivar o fluxo de turistas por meio desse atrativo cultural.

Pode-se citar como exemplos as iniciativas nominadas Goal to Brazil e Taste of Brazil que projetam a gastronomia brasileira para o trade turístico em diversos países por meio da participação de chefs brasileiros em feiras e eventos internacionais. Deve-se levar em conta que tais ações figuram de maneira dispersa nos documentos oficiais (Plano Nacional de Turismo e Plano Aquarela) e torna-se difícil acompanhá-las a não ser em documentos, textos e vídeos retirados da internet ${ }^{47}$.

No sentido de empreender o esforço necessário para revelar a complexa dinâmica entre a produção e o consumo — material e simbólico — da gastronomia paraense como atrativo turístico, ampara-se em discursos que ora se contradizem, ora se complementam. Com isso, busca-se realizar o détour que possibilite escapar da aparente "verdade" do discurso oficial do Estado que promove a gastronomia paraense como a mais "brasileira" do Brasil.

\subsection{AS PRÁTICAS E AS REPRESENTAÇÕES SIMBÓLICAS DA GASTRONOMIA EM BELÉM DO PARÁ}

A gastronomia paraense é repleta de imaginários. Muitos deles referem-se ao universo mitológico da floresta amazônica e constituem as bases para a formação da identidade e, por sua vez, da cultura e do patrimônio gastronômico local. Mitos associados à origem da mandioca e do açaí, por exemplo, permeiam o imaginário simbólico sobre a gastronomia paraense. Neste sentido, Lévi-Strauss (1978) lembra que o pensamento mitológico emerge na

\footnotetext{
${ }^{47}$ Disponível no link: < https://www.youtube.com/watch?v=gemAf55cIUk>. Acesso em: 26 abr. 2014.
} 
tentativa de encontrar respostas para os fenômenos do mundo sensorial, isto é, do mundo em que se vive e no qual se constituem as relações sociais, neste caso a floresta amazônica. Sob esse entendimento a respeito do pensamento mitológico, vale lembrar o relato de Cascudo (2004, p. 95) sobre a origem "sobrenatural" da mandioca:

Noutra tradição, colhida em Belém do Pará por Couto Magalhães, a filha de um chefe indígena engravidara sem contato masculino, como em sonho comunicara um homem branco ao pai furioso que se acalmou. Nasceu uma menina deslumbrante, de nome Mani, morta ao fim de um ano, sem doença e sem dor. Do túmulo surgiu arbusto novo. A terra fendeu-se, como mostrando o corpo da morta. Encontraram raízes que eram as primeiras mandiocas, fortificantes e poderosas. Mandioca, de Mani-oca, a casa de Mani. (Cascudo, 2004, p. 95)

Cada sociedade concebe sua maneira peculiar para expressar sua existência. Dessa forma, a "origem" mitológica dos alimentos segue a lógica descrita por Ribeiro (2006, p. 40) que sob o olhar do indígena, a vida era dádiva dos deuses. Assim, a priori, aos olhos dos paraenses, os alimentos são dádiva da floresta amazônica. A lenda do açaí também permeia o imaginário local como o fruto que alimenta e sustenta o paraense recebido de intervenção divina.

\begin{abstract}
Há muito tempo, quando ainda não existia a cidade de Belém, vivia no local uma tribo indígena muito numerosa. Como os alimentos eram escassos, tornava-se muito difícil conseguir comida para todos os índios da tribo. Então o cacique Itaki tomou uma decisão muito cruel: resolveu que a partir daquele dia todas as crianças que nascessem seriam sacrificadas para evitar o aumento populacional de sua tribo. Até que um dia a filha do cacique, chamada Iaçã, deu à luz uma bonita menina, que também teve de ser sacrificada. Iaçã ficou desesperada, chorava todas as noites de saudades de sua filhinha. Ficou vários dias enclausurada em sua tenda e pediu a Tupã que mostrasse ao seu pai outra maneira de ajudar o povo, sem o sacrifício das crianças. Certa noite de lua, Iaçã ouviu um choro de criança. Aproximou-se da porta de sua oca e viu sua linda filhinha sorridente, ao pé de uma esbelta palmeira. Inicialmente ficou estática, mas logo depois, lançou-se em direção à filha, abraçando-a. Porém, misteriosamente sua filha desapareceu. Iaçã, inconsolável, chorou muito até desfalecer. No dia seguinte, seu corpo foi encontrado abraçado ao tronco da palmeira, porém no rosto trazia ainda um sorriso de felicidade e seus olhos negros fitavam o alto da palmeira, que estava carregada de frutinhos escuros. Itaki então mandou que apanhassem os frutos em alguidar de madeira, obtendo um vinho avermelhado que batizou de AÇAÍ, em homenagem a sua filha (IAÇÃ invertido). Alimentou seu povo e, a partir desse dia, suspendeu a ordem de sacrificar as crianças. $^{48}$
\end{abstract}

Na página oficial de turismo do Pará, o universo mitológico é promovido como elemento que eterniza a presença da cultura indígena na sociedade atual. A fím de avançar na discussão, busca-se novamente o conceito defendido por Canclini (2001) que nos permite compreender o processo sócio-cultural em que as culturas se entrelaçam e tornam híbridas.

\footnotetext{
${ }^{48}$ Disponível em <http://www.paraturismo.pa.gov.br/?q=lendas>. Acesso em 01. Mai. 2015.
} 
Portanto convém dizer que a cultura indígena que se faz presente até os dias atuais é a própria cultura paraense resultante dos contínuos processos de hibridação cultural.

O paraense se reconhece como papa-chibé — comedor de farinha - e tem sangue cor de açai ${ }^{49}$. Certamente, essa relação histórica e afetiva com o alimento favorece a apropriação material e simbólica das práticas identitárias da gastronomia paraense para a produção e consumo turístico a partir desses elementos. Assim, em nosso entendimento, a promoção turística da gastronomia paraense diz respeito à promoção turística da identidade paraense.

A farinha de mandioca é o alimento que acompanha toda a vida do paraense. Seu consumo é indispensável no cotidiano e o "comer de arremesso" figura no imaginário como elemento identitário dos paraenses. Essa prática é comum nas feiras e mercados tradicionais de Belém onde os diversos tipos de farinha são comercializados a granel e costumam ser experimentados "de arremesso" antes da compra (figura 5).

Figura 5 - Diversidade de farinhas nos mercados e feiras de Belém

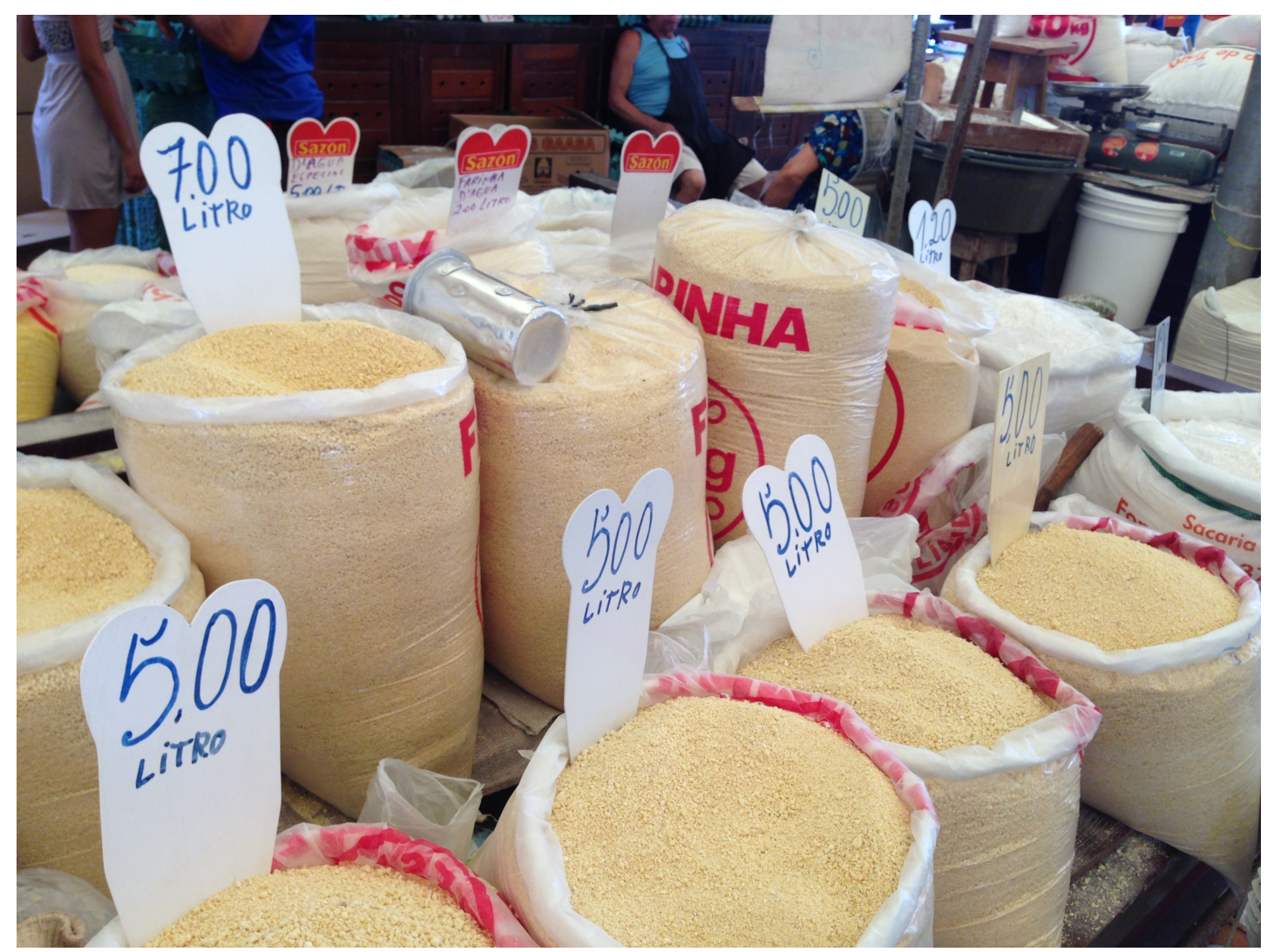

Fonte: acervo da autora (abril 2013)

\footnotetext{
${ }^{49}$ Essa interpretação da autora é possível a partir da pesquisa realizada em campo, das leituras de diversos autores e reforçada no documento Ver-o-Pará.
} 
A farinha d'água de Bragança, é notadamente, a mais valorizada pelos paraenses e, diante do "modismo" da gastronomia paraense, a mais disputada pelos chefs de cozinha brasileiros. ${ }^{50}$ No entanto, observa-se que o ofício artesanal dos mestres farinheiros bem como os artefatos utilizados na produção desse saber-fazer ainda estão apartados das políticas patrimoniais do estado.

Outro exemplo diz respeito ao impacto econômico - e diga-se cultural — que o aumento do preço da farinha, ocasionada por uma série de fatores que perpassam desde a queda do cultivo da mandioca ao incentivo para plantio de dendezeiros, traz para os paraenses (figura 6). ${ }^{51}$ No Pará, quando a farinha sobe de preço, as famílias sentem no bolso e reduzem o consumo (informação verbal) ${ }^{52}$.

Figura 6 - Preço da farinha e do açaí pesam no bolso do paraense

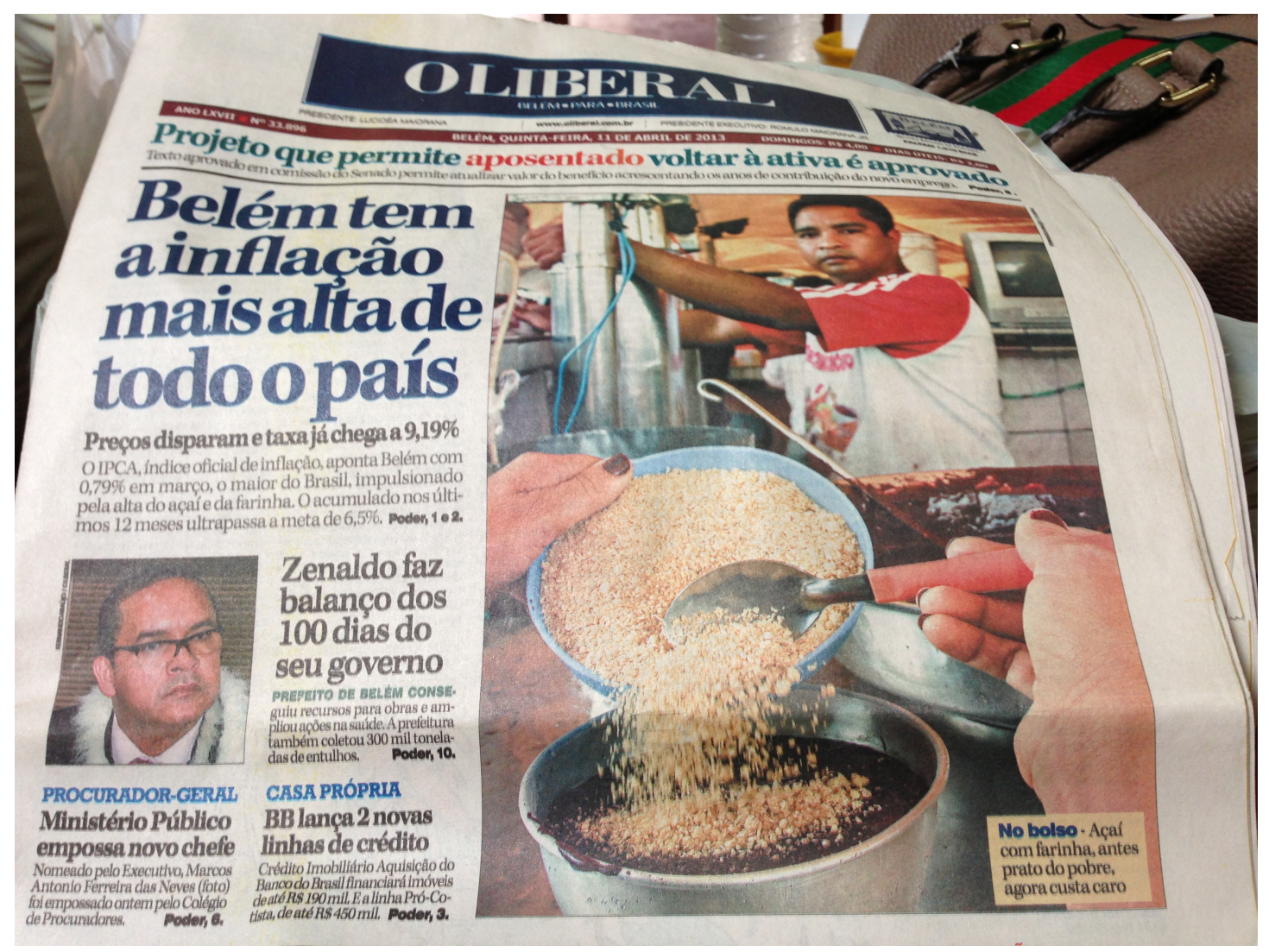

Fonte: acervo da autora (abril 2013)

50 Disponível em <http://www.diarioonline.com.br/noticia-249288-braganca-detem-a-fama-de-ter-a-melhorfarinha.html?9355087>. Acesso em 01. mai. 2015.

${ }^{51}$ A relação entre o incentivo para a produção de biodiesel na Amazônia, especialmente no Pará, e a queda na produção da mandioca pela substituição do cultivo ou pela adesão dos pequenos produtores rurais locais ao programa é apontado como um dos fatores responsáveis pelo aumento do preço da farinha (e de outros alimentos na mesa dos paraenses). Disponível em <http://diariodopara.diarioonline.com.br/N-165890MANDIOCA+SOME+E+FARINHA+VIRA++OURO.html>. Acesso em 01. mai. 2015.

${ }^{52}$ Depoimento de Raimundo Santos, feirante da ala de farinhas do Ver-o-Peso, que foi concedido para a autora no dia 12 de abril de 2013 em Belém-PA. 
Certamente, em nosso entendimento, o patrimônio cultural de um povo que se autodenomina "papa-chibé" deve incluir instrumentos de salvaguarda ao saber-fazer dos mestres farinheiros e aos diversos aspectos que envolvem o cultivo da mandioca e sua transformação na farinha que identifica os paraenses. Entre a produção e o consumo, a farinha de mandioca envolve um conjunto de práticas, relações sociais e representações simbólicas integram o patrimônio cultural e a identidade gastronômica local.

O imaginário da gastronomia paraense produz e reproduz a imagem em torno da originalidade e da autenticidade que está presente no discurso oficial do Governo do Estado do Pará. ${ }^{53}$ Essa afirmação pode ser reforçada no pensamento de Debord (1997), segundo o qual o espetáculo é ao mesmo tempo resultado e produto da visão de mundo em que se objetivou.

\begin{abstract}
Considerada uma das culinárias mais "brasileiras" do País, a gastronomia do Pará tem sim a cultura indígena como sua maior influência, mas também carrega consigo traços portugueses e africanos. Os elementos encontrados na região da Amazônia formam a base de seus pratos, com o acréscimo do camarão, caranguejo, pato e dos peixes, todos temperados com folhas e frutas nativas. Destacam-se: açaí, bacaba, cupuaçu, castanha-do-pará, bacuri, pupunha, tucumã, muruci, piquiá e taperebá -, pimentas de cheiro e ervas. Os mais tradicionais são cozidos em panelas de barro ou assados em moquéns e embebidos de tucupi, caldo amarelo extraído da mandioca. Aliás, a raiz é uma das bases da culinária paraense, e sua farinha não pode faltar nos pratos locais. 54
\end{abstract}

Por sua vez, entende-se que a sociedade em que se produz essas imagens é colecionadora de espetáculos, com destaque para os bens culturais, aqui incluindo as experiências turísticas e, por sua vez, a gastronomia e todas as suas práticas simbólicas. Diante da espetacularização da gastronomia paraense como elemento de estímulo ao "consumo" simbólico da capital do estado, assume-se a perspectiva da dialética entre a produção e o consumo dos bens culturais, no sentido de propor uma reflexão crítica para o desenvolvimento de ações e iniciativas que prospectam o produto "gastronomia" como elemento oficial da oferta turística local.

Como se observa, o Plano "Ver-o-Pará" 2020, o estado como o "Destino Líder da Amazônia" calcado em cinco valores que

\footnotetext{
${ }^{53}$ Discurso que apresenta a gastronomia paraense na página oficial do Governo do Estado do Pará a gastronomia paraense. Disponível em <http://www.pa.gov.br/O_Para/culinaria.asp>. Acesso em 01. mai. 2015.

${ }_{54}^{54}$ Disponível em $<$ http://www.pa.gov.br/O_Para/culinaria.asp $>$. Acesso em 01. mai. 2015.

${ }^{55}$ O Plano Estratégico de Turismo do Estado do Pará 2012-2020 descreve o planejamento turístico do estado a partir de dois núcleos: a promoção do turismo, sob responsabilidade da Paratur (Companhia Paraense de Turismo), e o desenvolvimento de novos produtos turísticos bem como o fortalecimento das políticas públicas de turismo, sob responsabilidade da Setur (Secretaria de Turismo do Estado) (BRASIL, 2011).
} 
expressam, segundo o próprio documento, o diferencial da oferta turística do destino: originalidade, autenticidade, criatividade, diversidade e sustentabilidade. ${ }^{56}$ Assim, entende-se que para consolidar o estado na condição de destino de líder da Amazônia toda a atuação pública e privada, tanto em nível de desenvolvimento quanto no posicionamento da imagem, passa a ser orientada por esses princípios norteadores.

Embora seja um elemento intangível a ser trabalho, o posicionamento da imagem é considerado um dos ativos mais importantes do turismo para o estado (BRASIL, 2011, p. 69). Assim, manifesta o intuito de firmar-se como destino líder sob os seguintes pressupostos:

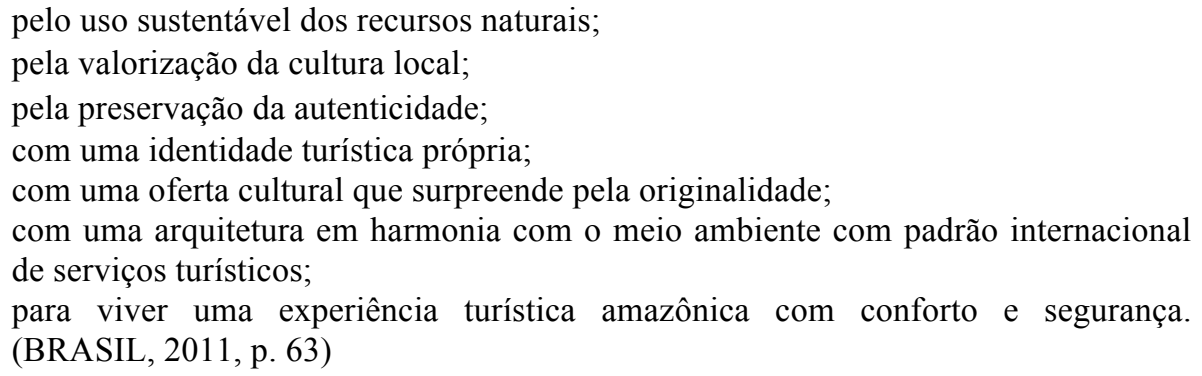

O Plano Ver-o-Pará tem como premissa a função de "fazer acontecer" com base na implementação de ações de curto prazo sincronizadas com o planejamento estratégico e a visão de longo prazo (BRASIL, 2011, p. 11). De acordo com as informações apresentadas no documento, foi realizado um diagnóstico situacional sobre o turismo no Pará para o qual foram considerados os seguintes eixos estruturantes:

Os volumes atuais do turismo no mundo, no âmbito internacional e nacional, onde foram considerados também os movimentos turísticos internacionais específicos do segmento de ecoturismo ou turismo de natureza.

A atividade turística no Pará, referenciada por séries históricas que permitiram, a partir da reconstrução do processo evolutivo compreender o estágio de desenvolvimento e desempenho econômico do turismo no Estado.

O território, as infraestruturas de acesso e os serviços turísticos, existentes e em fase de projeto.

A situação do produto Pará nos canais de comercialização do mercado local, nacional e internacional.

A situação dos recursos, produtos e da oferta turística atual dos seis polos turísticos do Estado do Pará.

A opinião interna, ou seja, a percepção dos gestores públicos, empresários, profissionais e representantes da sociedade civil sobre a situação do turismo no destino Pará.

A opinião externa, ou seja, a avaliação que o turista atual que visita o Pará, levantada por meio de pesquisa qualitativa, faz sobre os produtos e destinos do Estado.

\footnotetext{
${ }^{56}$ Esses valores estão sintetizados no termo que o Plano descreve como "decálogo", isto é, argumentos estruturados para trabalho do trade turístico na oferta do destino Pará para potenciais turistas.
} 
A política turística nas três esferas de governo, em âmbito federal, estadual e municipal. (BRASIL, 2011, p. 11)

Com isso, o planejamento estratégico do turismo no estado passou a seguir os aspectos objetivos da segmentação de mercado no sentido de priorizar esforços e recursos para atingir a meta de tornar o Pará o Destino Líder da Amazônia até 2020. Evidencia-se também que a metodologia utilizada para formulação do Plano Ver-o-Pará utiliza os princípios mercadológicos propostos por Josep Chias diante da construção da imagem do destino ${ }^{57}$ (BRASIL, 2008, p. 40).

Com base nesse entendimento, a formulação dos valores intrínsecos ao destino, tratado como mercadoria, são objetivados no sentido de conferir-lhe um posicionamento distintivo na percepção do turista. Com isso, as dimensões culturais e as práticas sociais simbólicas são reificadas para atender às estratégias da imagem almejada e a comunidade, parte indispensável para que a experiência turística seja realizada em sua essência, passa a figurar em segundo plano.

É relevante destacar o pensamento que direciona os aspectos de valoração e valorização dos atributos turísticos do estado elencados no Plano Ver-o-Pará:

[...] Os "recursos" são os atrativos (patrimônio natural, cultura, clima) e a população que vive no território. Quando esses recursos são estruturados para uso turístico, transformam-se em produtos. Assim, entende-se que um "produto" é aquele recurso que oferece a possibilidade para a prática de uma atividade turística (visitar, assistir, participar, estudar, comprar, comer), porque foram organizadas propostas para o visitante usufruir do atrativo e estabelecidas condições de acessibilidade para o público (BRASIL, 2011, p. 38).

Como se vê, o Plano Ver-o-Pará aponta que os paraenses e seu patrimônio natural e cultural podem ser estruturados para o uso turístico. Com o objetivo de determinar o valor potencial e grau de aproveitamento atual dos "recursos" disponíveis, isto é, dos atrativos turísticos potenciais ao olhar do turista, para citar Urry (2001), o Plano Ver-o-Pará adotou os critérios de "singularidade", "valor intrínseco" e "identidade local”. As definições conceituais dos critérios adotados estão detalhadas a seguir e serviram como parâmetro para hierarquização dos atributos.

Singularidade: o que distingue um recurso pelo fato de ser único no Mundo, na América Latina, no Brasil ou no Estado. Quanto mais raro, maior será o âmbito de atração geográfica do mesmo.

\footnotetext{
${ }^{57}$ É importante destacar que a consultoria Chias Marketing contratada para realizar o planejamento estratégico e o posicionamento do destino Pará segue a metodologia de Josep Chias que serviu como base para a construção do Plano de Marketing Aquarela e derivou no posicionamento de imagem do Brasil. Esse fato, demonstra o encadeamento entre o discurso do estado com as diretrizes em nível federal uma vez que baseia-se nos mesmos princípios metodológicos.
} 
Valor Intrínseco: valor inerente a cada um dos recursos, mas que comparativamente o destaca dentro da sua própria categoria (museus, prédios, natureza, parques).

Identidade local: valor que tem um recurso pelo fato de ser do próprio local, mesmo que não seja especificamente um recurso turístico. $\mathrm{O}$ mercado reconhece o diferencial naquilo que forma parte da identidade do lugar (BRASIL, 2011, p. 39).

Assim, o discurso explícito que idealiza o "universo de cores e sabores" da gastronomia paraense como a mais "brasileira" do país ${ }^{58}$ passa a desencadear novos discursos que reafirmam a mesma imagem que foi idealizada para o turista. A Companhia Paraense de Turismo (Paratur), por exemplo, destaca que a gastronomia paraense "é considerada a mais autêntica e exótica do país e responsável por colocar o Pará em destaque no roteiro turístico gastronômico nacional",59 (figura 7).

Figura 7 - Notícia que mostra o posicionamento de Belém no mapa da gastronomia

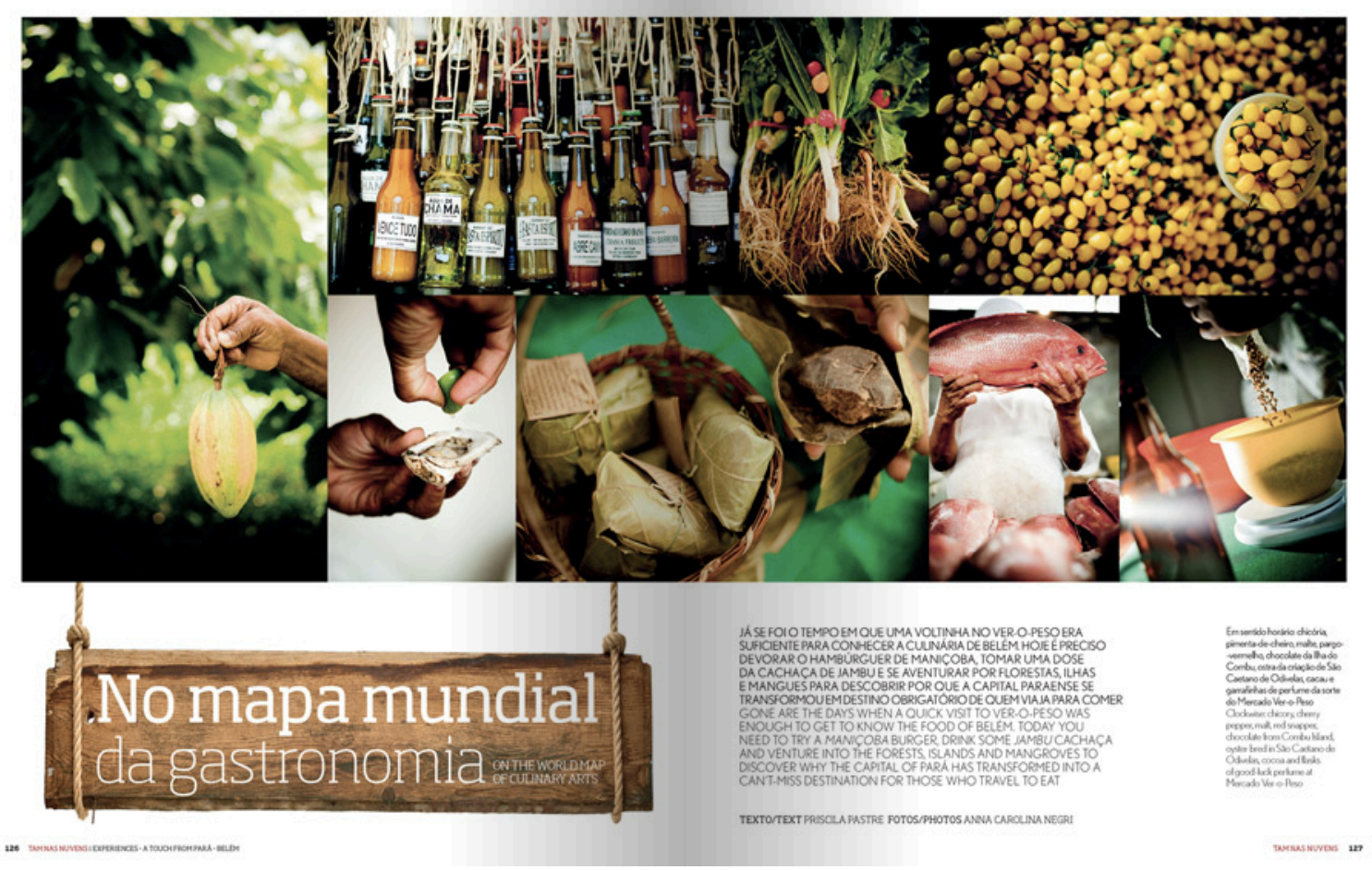

Fonte: Revista TAM Nas Nuvens, página 129, Edição nº 73, janeiro de 2014.

Procura-se chamar a atenção para o processo de espetacularização e mercantilização do destino e de sua gastronomia explícito na imagem e no texto no qual Belém configura-se

\footnotetext{
${ }^{58}$ Informações sobre a "culinária paraense" disponibilizadas no Portal do Governo do Estado do Pará. Link para acesso: http://www.pa.gov.br/O_Para/culinaria.asp. Consulta realizada em 21/03/2015.

${ }_{59}$ Trecho do texto de apresentação sobre a gastronomia paraense retirado do site da Paratur. Link para acesso: http://www.paraturismo.pa.gov.br/?q=gastronomia. Consulta realizada em 21/03/2015.
} 
como destino obrigatório para os turistas que viajam para "comer". O texto da reportagem informa aos turistas que "já se foi o tempo em que uma voltinha no Ver-o-Peso era suficiente para conhecer a culinária de Belém" e seria necessário percorrer a cidade em busca dos "novos sabores locais". É preciso reconhecer a relação dialética do discurso que incentiva o turista a experimentar o tradicional mas também a se aventurar pelo novo.

Entre os atrativos turísticos da cidade, o tradicional Mercado Ver-o-Peso é um local de comercialização de ingredientes e comidas tracionais frequentado não apenas por turistas mas, principalmente, por moradores. Inaugurado em 1627, o “veropá" como é conhecido pelos belenenses foi tombado pelo Instituto do Patrimônio Histórico e Artístico Nacional (Iphan), em 1997, e inscrito, em abril de 2014, como um dos bens culturais que a serem indicados à Lista do Patrimônio Mundial da Organização das Nações Unidas para a Educação, a Ciência e a Cultura (Unesco). É considerável a importância histórica, econômica e social do Ver-o-Peso para Belém que se configura sobretudo como espaço de fruição e produção da cultura local, símbolo da identidade paraense.

Outro importante símbolo da identidade paraense é materializado na figura das tacacazeiras distribuídas pelas ruas de Belém. Consideradas patrimônio cultural imaterial de Belém $^{60}$ e do Estado do Pará ${ }^{61}$, disputam moradores e, agora, turistas, em busca do melhor tacacá da cidade, conforme se observa no texto da lei municipal que institucionaliza as vendedoras de tacacá no rol do patrimônio cultural da cidade.

Art. $1^{\circ}$. Fica, a vendedora de Tacacá, declarada como Patrimônio Cultural Imaterial para o Município de Belém para todos os efeitos legais, reconhecendo a importância cultural desta atividade para o circuito turístico brasileiro. (PARÁ, 2013)

Hábito presente no cotidiano dos paraense, o tacacá é um preparo tradicional elaborado com goma de mandioca, camarão seco, tucupi e jambu. O tucupi ${ }^{62}$ é um molho preparado artesanalmente cuja receita é passada de geração em geração pelas famílias e as tacacazeiras podem ser consideradas guardiãs dessa identidade. Assim, cada tacacazeira tem sua receita e cada tacacá tem um sabor (informação verbal) ${ }^{63}$.

\footnotetext{
${ }^{60}$ As tacacazeiras, vendedoras de tacacá, foram declaradas Patrimônio Cultural Imaterial de Belém pela Lei $n^{\circ}$ 8.979 de 3 de janeiro de 2013. Disponível em < http://www.belem.pa.gov.br/diarioom/index.jsf>. Acesso em 1 . mai. 2015.

${ }^{61}$ Lei $\mathrm{n}^{\mathrm{o}} 7.752$ de 28 de novembro de 2013. Disponível em < http://www.ioepa.com.br/portal/\#1>. Acesso em 1 . mai. 2015.

${ }^{62}$ Tucupi é um molho fermentado extraído da mandioca-brava que em seu processo de fabricação precisa ser fervido durante 4 a 5 horas até a evaporação do ácido cianídrico que existe em sua composição. É utilizado como tempero em diversos preparos da gastronomia paraense como o pato no tucupi e o tacacá.

${ }^{63}$ Depoimento de Bito (José Soero), filho da tacacazeira Maria do Carmo Pompeu dos Santos (in memoriam), concedido para a autora no dia 13 de abril de 2013 em Belém-PA.
} 
Portanto, cada tacacazeira de Belém fideliza seu público em razão das particularidades associadas ao sabor do tucupi - elemento que distingue um tacacá do outro. Ao mesmo tempo, a representação simbólica das tacacazeiras passa a integrar o imaginário dos turistas que necessariamente precisam experimentar o tacacá ao visitar Belém (figura 8).

Figura 8 - As tacacazeiras integram o patrimônio cultural de Belém

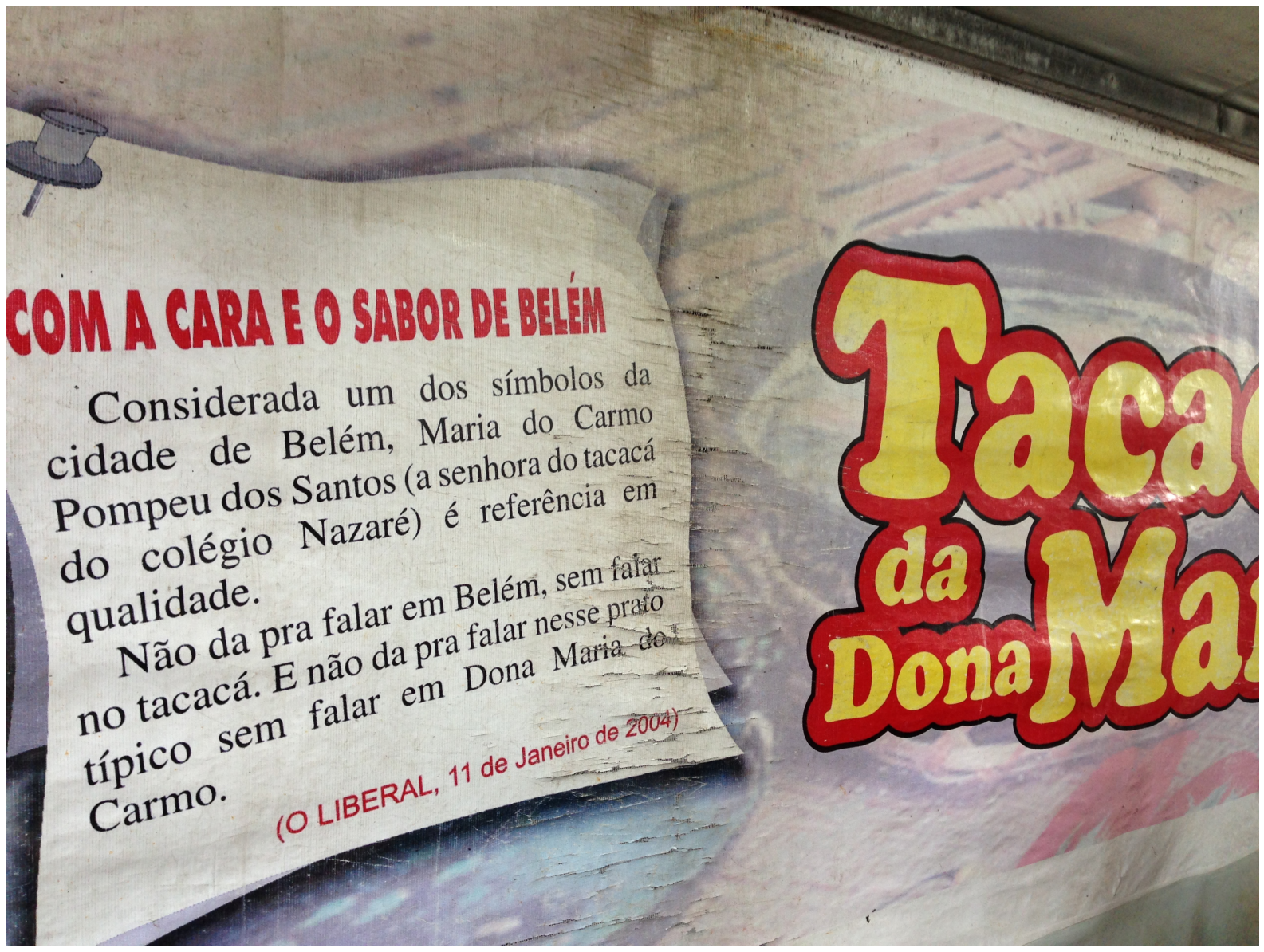

Fonte: foto da autora (abril de 2013).

Até aqui, a leitura realizada com base nas lentes metodológicas utilizadas nesta pesquisa permite apreender que o posicionamento do destino Pará incorpora o patrimônio cultural e a identidade gastronômica ao conjunto de atrativos merecedores do movimento do "olhar do turista" e que Belém concentra os elementos necessários para a produção e consumo desses bens culturais.

Essa reflexão possibilita entendimento menos simplificador sobre o interesse público em identificar e promover aspectos estéticos e culturais dos destinos turísticos entre os quais a "singularidade" e a "identidade local". Tomando-se por base o estímulo ao desenvolvimento das denominadas "qualidades especiais", esses elementos tornam-se mercadorias negociáveis 
com vistas ao incremento do fluxo de turistas na expectativa de usufruir economicamente dos benefícios associados ao turismo.

Para Harvey (2005, p. 223), a contradição consiste exatamente na negociabilidade dos aspectos que tornam os itens particulares ou singulares, pois na medida em que incorporam um valor monetário tendem a reduzir seu valor de exclusividade.

Em alguns casos o próprio marketing tende a destruir as qualidades exclusivas (em
especial, se essas dependem de qualidades como vastidão selvagem, grande
distância, pureza de alguma experiência estética etc). Geralmente, quanto mais
facilmente negociáveis são tais, itens ou eventos (e sujeitos à replicação por
falsificações, fraudes, imitações ou simulacros), menos eles proporcionam a base
para a renda monopolista (HARVEY, 2005, p. 223).

Outro aspecto importante a destacar consiste nos aspectos decorrentes da homogeneidade cultural na pós-modernidade, proposta por Hall (2014), que tendem a suprimir as vantagens monopolistas ao igualar os bens culturais e afastar deles os elementos de distinção e classificação.

Para Harvey (2005, p. 227), as expressões culturais estão cada vez mais sintonizadas “com as tentativas de reassegurar tal poder monopolista, exatamente porque as alegações de singularidade e autenticidade podem ser melhor articuladas enquanto alegações culturais distintivas e irreplicáveis". O autor aponta que a incessante busca pela manutenção dos aspectos únicos e particulares das mercadorias ou lugares (transformados em mercadorias), generaliza, nos atores e produtores interessados no controle desse poder, o discurso da autenticidade, originalidade, singularidade e qualidades irreplicáveis (2005, p. 229).

Portanto, na medida em que a pós-modernidade iguala e destrói as características irreplicáveis dos bens culturais e a busca se dá em razão das vantagens em se manter essas qualidades, configura-se um cenário para a reprodução do real, isto é, para a construção de simulacros (BAUDRILLARD, 1991). Nesse processo, a gastronomia paraense tende a ser copiada e reproduzida por um conjunto de atores sociais que desejam ampliar sua renda em virtude das "qualidades especiais" que o bem representa no imaginário coletivo (HARVEY, 2005).

Com efeito, ao apropriar-se de uma identidade e da íntima relação afetiva que o paraense tem com sua gastronomia, as políticas públicas concebidas para produção e consumo dessa identidade tendem a apresentar resultados satisfatórios. ${ }^{64}$ Percebe-se, com base no Plano

\footnotetext{
${ }^{64}$ Segundo os dados oficiais do relatório de três anos de implantação do Plano Estratégico de Turismo Ver-oPará, realizado no dia 11/11/2014, na sede Federação das Indústrias do Estado do Pará (Fiepa) os resultados obtidos tanto em volume total de turistas nacionais e internacionais quanto em receita (em US\$) têm sido
} 
Ver-o-Pará, que as formas singulares de expressão da gastronomia paraense destacaram-se como elemento extraordinário ao "olhar do turista".

Assim, o planejador público do turismo confere destaque à gastronomia paraense como um importante elemento da cultura local que permeia a oferta turística do estado e da capital, Belém. Vale dizer que o discurso da autenticidade, originalidade, singularidade e qualidades irreplicáveis, enfatizados por Harvey (2005), está amplamente disseminado no discurso oficial do turismo no estado, inclusive, pode-se conferir a descrição valorativa desses aspectos no portal oficial de turismo da Prefeitura de Belém ${ }^{65}$ :

A Gastronomia do Pará apresenta como maior destaque a cultura indígena com nítida influência portuguesa e africana. É considerada a mais autêntica do Brasil, justamente pelas suas características regionalíssimas. Os ingredientes básicos são oriundos da exuberante natureza (fauna e flora) da Amazônia, como camarão, caranguejo, marisco, peixe, caças, pato, suas famosas ervas, chicória, coentro, jambu, pimentas de cheiro.

Das farinhas retiradas da mandioca, famosas pela qualidade, a mais apreciada é a farinha d'água. Produz-se ainda goma para tapioca ou beijus, que tem a forma de uma panqueca e pode levar vários tipos de recheio como chocolate, queijos ou geleia, sendo mais comum o seu consumo apenas com manteiga ou coco ralado. A tapioquinha é consumida frequentemente como café da manhã ou lanche da tarde, geralmente acompanhada de café com leite. É uma iguaria de gosto suave porém característico e pode ser encontrada em estabelecimentos simples, carrinhos, lanchonetes e existem até Tapiocarias, lanchonetes que vendem apenas tapiocas com os mais variados tipos de recheios.

Há também o tucupi, caldo amarelo extraído da mandioca, que não dá para descrever seu maravilhoso sabor sem prová-lo, seja acompanhando carne, peixe, mariscos ou puro, quente-quase fervendo, com ou sem jambu. E, sem esquecer, uma das principais iguarias do Estado, o pato no tucupi ${ }^{66}$.

Por outro lado, cabe destacar que uma série de preparações regionais como "pato no tucupi", "maniçoba”, “caruru”, “tacacá”, "vatapá"67 e "chibé” foram inscritas simbolicamente como bens representativos do patrimônio alimentar paraense (figura 9). Torna-se oportuno conhecer um pouco mais sobre essas "comidas típicas" que são reconhecidas como

superiores às metas estabelecidas. Disponível para consulta no site da Secretaria de Estado de Planejamento do Pará. Disponível em: <http://www.sepof.pa.gov.br>. Acesso em: 10 de mai. 2015.

${ }^{65}$ De acordo com as informações retiradas do próprio site, BelemTur é a Coordenadoria Municipal de Turismo do município de Belém e tem como objetivo: planejar, coordenar, controlar e avaliar as atividades relacionadas com o turismo no município do Belém, nos Termos da Política Nacional de Turismo. (Disponível em: $<$ http://www.belem.pa.gov.br/belemtur/site/?page_id=241>. Acesso em: 30 mai. 2014

${ }^{66}$ Disponível em: <http://www.belem.pa.gov.br/belemtur/site/?page_id=92>. Acesso em: 30 mai. 2015.

${ }^{67}$ Em virtude da falta de informações a respeito do "vatapá" nas referências disponibilizadas no portal do estado, optamos por pesquisar esses dados na literatura gastronômica. Dessa forma, concluímos que essa "comida típica" é um elaborada à base de camarão seco, farinha de mandioca e leite de coco e pode ser encontrada em diversas regiões brasileiras mas no Pará costuma ser servida com folhas de jambu (CASTANHO; BIANCHI, 2013). 
patrimônio cultural de natureza imaterial para o Estado do Pará ${ }^{68}$. De acordo com as informações oficiais disponíveis no portal do estado, ${ }^{69}$ descreve-se esses preparos com as seguintes características:

- pato no tucupi: constituído de pato, tucupi e jambu. O tucupi é um caldo amarelo extraído da mandioca e por isso precisa ser cozido durante uma semana. O pato, depois de assado, é cortado em pedaços e fervido no tucupi, onde fica de molho por algum tempo. O jambu é fervido em água com sal, escorrido e posto sobre o pato. É servido com arroz branco e farinha de mandioca.

- maniçoba: do tupi Maní, deusa da mandioca. Usa-se tipicamente uma panela de barro ou de porcelana. O prato demora pelo menos uma semana para ser feito, pois a folha da maniva (a planta da mandioca), depois de moída, deve ser cozida durante, pelo menos, quatro dias com a intenção de eliminar o ácido cianídrico que contém. Depois disso é acrescentado o charque, toucinho, bucho, mocotó, orelha, pé e costelas salgadas de porco, chouriço, linguiça e paio, praticamente os mesmos ingredientes de uma feijoada completa. É servido com arroz branco, farinha d'água e pimenta de cheiro a gosto.

- caruru: feito com quiabo, camarões secos e inteiros, tempero verde (alfavaca e chicória), farinha seca bem fina e azeite de dendê. Após fervidos o quiabo, o tempero verde e os camarões na água, acrescenta-se a farinha e faze-se um pirão. estando pronto o pirão, adicionam-se os quiabos bem escorridos, o camarão já refogado com todos os temperos e, por último, o azeite de dendê.

- tacacá: de origem indígena, o Tacacá é um mingau quase líquido servido em cuias e vendido pelas "tacacazeiras", geralmente ao entardecer, na esquina das principais ruas das cidades paraenses, sobretudo Belém. É constituído de uma mistura que leva tucupi, goma de tapioca cozida, jambu e camarão seco.

- chibé: vocábulo tupi, composto de Che - eu, meu - e Ibe ou Tibe - caldo. É considerada a mais paraense de todas as comidas. Uma bebida com um gosto levemente acidulado. Leva farinha de mandioca e água.

Figura 9 - Comida típica é reconhecida como patrimônio cultural do Pará

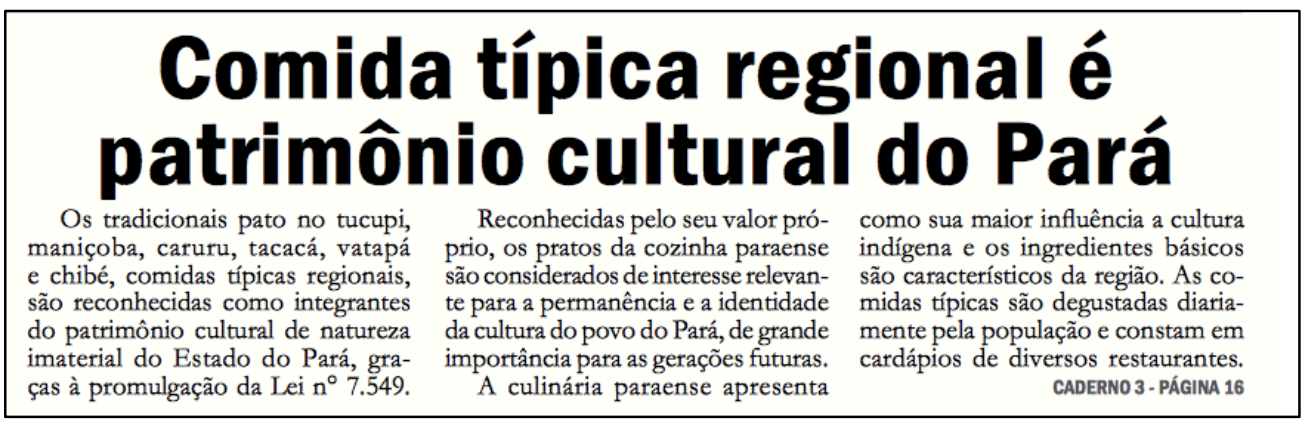

Fonte: Imprensa Oficial do Estado (IOEPA) ${ }^{\mathbf{7 0}}$

\footnotetext{
${ }^{68}$ A Lei $\mathrm{N}^{0} 7.549$ de 12 de setembro de 2011 da Assembleia Legislativa do Estado do Pará reconhece seis comidas típicas como integrantes do patrimônio cultural imaterial paraense.

${ }^{69}$ Informações retiradas do Portal do Estado do Pará que, entre outros, aborda a "História", "Gente", "Economia" e, também, o tópico "Culinária". No portal, não há menção ao reconhecimento a esse patrimônio cultural e das seis "comidas típicas" reconhecidas não foram encontradas referências ao "vatapá". Ao mesmo tempo, além da menção às cinco "comidas típicas" patrimonializadas, existe destaque para outras outras duas referências da cultura alimentar local: "doces" e "mujica". Disponível em: <http://www.pa.gov.br>. Acesso em: 03 ago. 2014.
} 
Antes de ser estruturado como um componente oficial da oferta turística do estado, o processo de consolidação da gastronomia paraense como elemento valorativo da cultura local foi embrionado em um festival gastronômico. ${ }^{71}$ Nesse processo de estimular o fluxo de profissionais, pesquisadores e turistas em busca da complexidade de "saberes e sabores" da região, Belém posicionou-se como promissor destino para consumo dessas experiências.

Essa dinâmica revela a valoração dos contínuos processos de hibridação cultural delineados, inclusive, pelos padrões geográficos configurados pela biodiversidade endêmica local. Em busca dos benefícios da renda monopolista invocam-se aspectos como "singularidade", "autenticidade" para conferir à gastronomia paraense o caráter valorativo da mercadoria "rara e exclusiva".

Como se viu, o tucupi é um dos elementos simbólicos da gastronomia paraense e componente essencial do "tacacá" e do "pato no tucupi". Vale lembrar que ambos os preparos são registrados como patrimônio cultural imaterial do estado, isto é, figuram no plano da representação. Embora não tenha sido objeto do reconhecimento oficial como patrimônio cultural, observa-se que o açaí é outro importante elemento simbólico da gastronomia paraense sendo que a espécie nativa é amplamente consumida fora da região amazônica e do Brasil.

No que se refere à imagem e à construção do simbólico, o Plano Ver-o-Pará institucionaliza a "cor do açaí", “os grafismos da cultura Marajoara, Tapajônica e Povos Indígenas do Xingu" e a "natureza Amazônica" a uma mensagem permanente "Pará, obraprima da Amazônia” (BRASIL, 2011, p. 67). Portanto, a atenção a essas representações culturais deve ser uma preocupação contínua da atividade turística.

Volta-se novamente o olhar para o Plano Ver-o-Pará e para a imagem construída em torno de conceitos intangíveis como a "cor do açaí" que passa a ser associada ao orgulho de ter o sangue com a cor de um fruto regional "autêntico". No entanto, a espetacularização da gastronomia paraense pode trazer impactos sociais como a perda da identidade. À medida que o açaí torna-se uma commodity, as comunidades extrativistas deixam de tirar o "bebe", isto é, deixam de tomar o açaí do dia que tradicionalmente integra a alimentação diária e, por essa razão, torna-se elemento identitário do paraense, para vender toda a produção e garantir assim o sustento da família (informação verbal) ${ }^{72}$.

\footnotetext{
70 Matéria publicada pela Imprensa Oficial do Estado do Pará. Disponível em: $<$ http://www.ioepa.com.br/diarios/2011/09/16.09.caderno.01.pdf $>$. Acesso em: 03 ago. 2014

${ }^{71}$ O Festival Ver-o-Peso da Cozinha Paraense que já está na $13^{\mathrm{a}}$ edição (o primeiro evento foi realizado em 2000).

${ }^{72}$ Depoimento de Tainá Marajoara concedido para a autora no dia 19 de abril de 2015 em Brasília-DF.
} 
Um dos diferenciais apontados pelo Plano Ver-o-Pará para alcançar a meta proposta de ser o destino líder da Amazônia até 2020 está fundamentado no fomento às práticas relacionadas ao uso e manejo sustentável dos recursos e da biodiversidade. Tomando-se por base este enfoque, cabe relacionar os pilares da sustentabilidade ${ }^{73}$ propostos por Sachs (2008) em todas as etapas do desenvolvimento e promoção do turismo, isto é, o turista deve ser incentivado não apenas a experimentar a gastronomia local mas, também, a valorizar a produção associada como forma de preservar as tradições e salvaguardar o saber-fazer na própria comunidade.

Parece relevante dizer que o governo (aqui órgãos oficiais de turismo do Estado) tem uma grande responsabilidade com o discurso, pois ele é porta-voz do povo. Portanto, a espetacularização da gastronomia paraense atende aos interesses do mercado turístico, mas as políticas públicas devem ser orientadas para o fortalecimento cultural e para a proteção das manifestações tradicionais.

Considerar o turismo como um fenômeno complexo se torna fundamental na construção das políticas públicas e na tomada de decisão para que os impactos (positivos e negativos) da atividade possam ser mensurados e monitorados na tentativa de atingir as metas propostas de maneira sustentável. A singularidade da gastronomia paraense se sustenta na presença desses preparos tradicionais e na forte influência da biodiversidade endêmica, o que lhe confere identidade e nítida diversidade em relação ao restante do país. ${ }^{74}$

Diante dessas "qualidades especiais", o sistema de representações culturais que confere identidade à gastronomia paraense apropria-se do seu valor simbólico para conferirlhe um novo valor material. Sob o olhar dialético entre a produção e o consumo dos bens culturais, essa relação pode ser percebida no discurso dos órgãos de fiscalização que discute a padronização da produção e da venda de tucupi ${ }^{75}$ e no uso do selo "produzido no Pará" que confere "autenticidade" e "originalidade" ao produto (figura 10).

É notório pensamento de Harvey ao dizer que nenhum bem é tão "único" ou “especial" que não possa ser negociado — incluindo o estímulo ao turismo cultural para consumo de determinado bem cultural. Certamente, essa característica favorece a destruição

\footnotetext{
${ }^{73}$ Para o autor Ignacy Sachs, as dimensões da sustentabilidade (social, ambiental, cultural, ecológica, territorial, política nacional e internacional) devem figuram em todas as etapas do desenvolvimento.

${ }^{74}$ Essa alteridade em relação à cultura alimentar de outras regiões do país, tornou-se ainda mais perceptível após a viagem que esta pesquisadora realizou à Belém para participar das atividades do Festival Ver-o-Peso da Cozinha Paraense em 2013 e deparou-se com o "cardápio cotidiano" local fortemente influenciado pela biodiversidade endêmica da região, o que lhe confere o caráter "exótico" até mesmo para os brasileiros de outras regiões.

${ }_{75}$ Disponível em <http://g1.globo.com/pa/para/noticia/2014/09/reuniao-discute-padronizacao-na-venda-detucupi-e-maniva-em-belem.html>. Acesso em 01. mai. 2015.
} 
dessas mesmas qualidades, pois "quanto mais facilmente negociáveis se tornem tais itens, menos únicos e especiais eles se afiguram” (HARVEY, 2005, p. 223).

Figura 10 - O tucupi com o selo e assinatura do chef de cozinha Paulo Martins

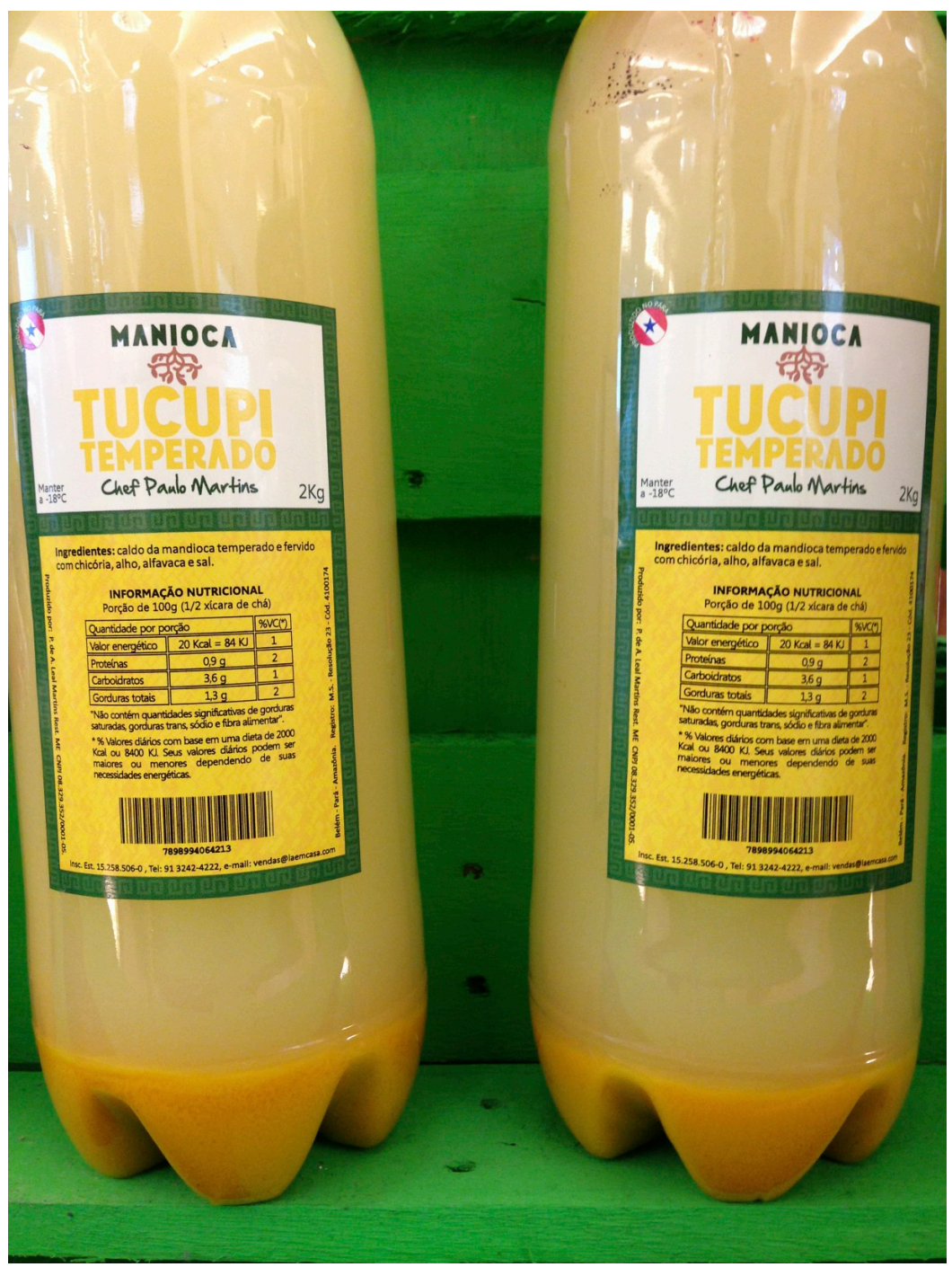

Fonte: Acervo da autora (abril de 2013).

Portanto, ao mesmo tempo em que a padronização do tucupi pode ser favorável para a promoção da gastronomia paraense, também pode destruir as características que o incorporam ao conjunto de práticas e simbologias do patrimônio cultural e da identidade gastronômica local. Nesse ponto, a nosso ver, se o elemento que confere sabor ao tacacá é padronizado, todos os tacacás terão o mesmo sabor e o ofício das tacacazeiras passaria a representar um simulacro da identidade que expressava anteriormente.

De maneira geral, a homogeneização cultural tende a promover experiências "autênticas" sem a necessidade do deslocamento para o local onde se produz determinada 
cultura. Esse parece ser o conceito disseminado atualmente nos restaurantes dos grandes centros urbanos como São Paulo e Rio de Janeiro. Dória (2014) destaca que nesses locais ocorre uma "estilização" da gastronomia cuja característica consiste em interpretar as tradições e proporcionar uma nova experiência gastronômica "passível de encantar os comensais" e ao mesmo tempo atrair turistas e prêmios internacionais. ${ }^{76}$

Assim, algumas referências dessa gastronomia que antes estavam restritas aos hábitos locais ganham representatividade nacional e internacional e passam a integrar o "cardápio" de prestigiados restaurantes ${ }^{77}$ (figura 11). A alusão aos "sabores" paraenses seduzem facilmente pelas perspectivas lucrativas da mercadoria e dos turistas em busca de experiências colecionáveis numa sociedade espetacular (DEBORD, 1997; HARVEY, 2005; URRY, 2001).

Figura 11 - Peixe no tucupi (prato servido no restaurante Maní em São Paulo)

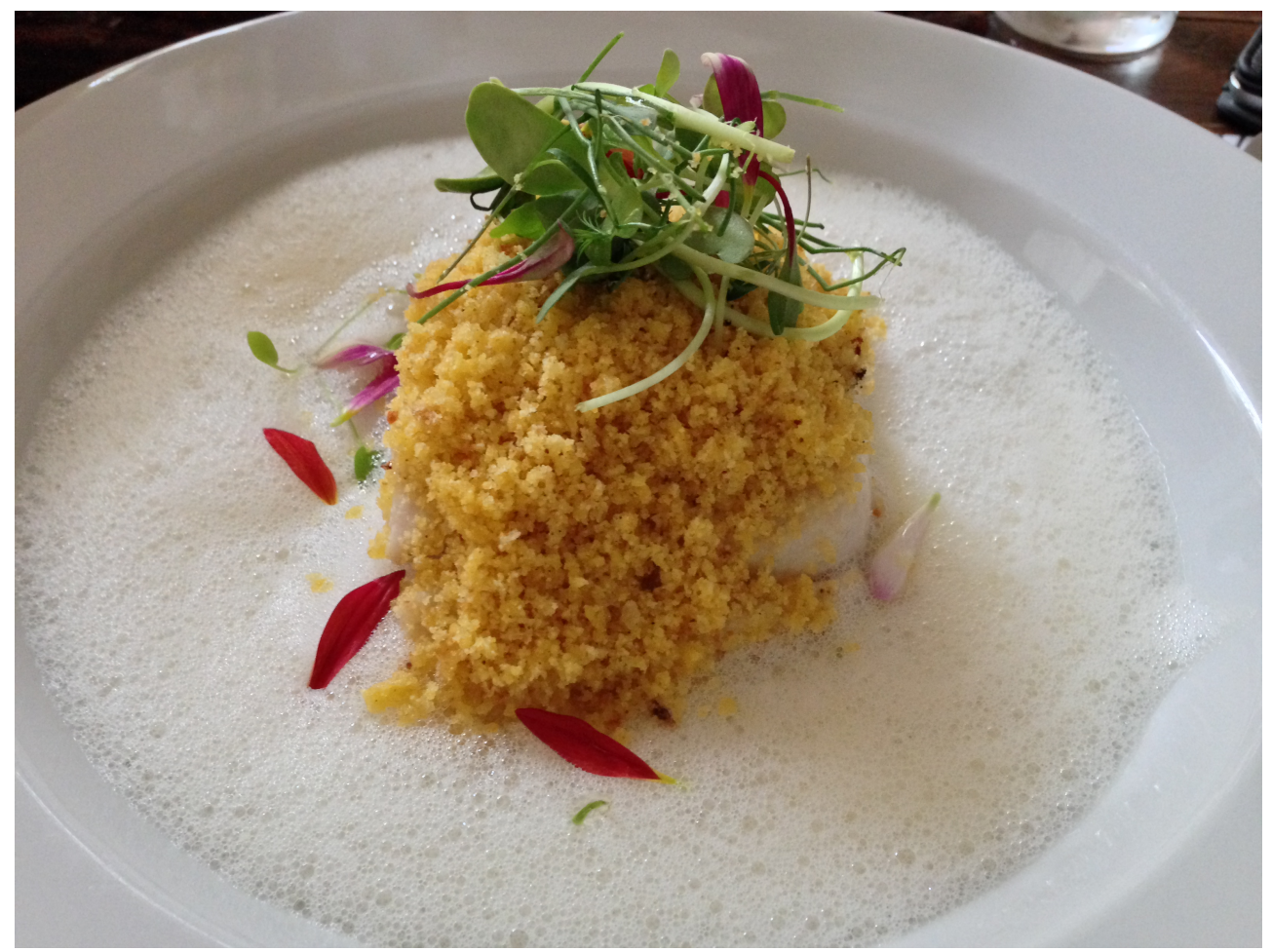

Fonte: Acervo da autora (novembro de 2013).

Logo, a contradição existente entre a valorização dos elementos "puros" e "originais" da gastronomia paraense e sua comercialização como atrativo turístico requer um esforço de

\footnotetext{
${ }^{76}$ Cabe ressaltar nesta dissertação que os restaurantes brasileiros que "estilizaram" a gastronomia brasileira passaram a conquistar admiradores e receber contínuo reconhecimento nos mais seletos rankings da gastronomia internacional, como o da revista Restaurant citada em outros momentos nesta pesquisa.

${ }^{77}$ Considerado um dos 50 melhores restaurantes do mundo pela revista Restaurant, o Maní também recebe destaque duplo pois a chef brasileira Helena Rizzo foi eleita pela mesma publicação como a melhor chef de cozinha feminina do mundo em 2014.
} 
resistência coletiva para que esses itens não sejam destruídos e replicados como meras representações dessa identidade (BAUDRILLARD, 1991). O olhar dialético deve estar atento à essa questão em razão da importância que o turismo adquire numa sociedade globalizada que "gira em virtude dos sonhos e desejos dos turistas", segundo a visão de Bauman (1999).

Ao integrar oficialmente seis "comidas típicas" (pato no tucupi, maniçoba, caruru, tacacá, vatapá, chibé) ao patrimônio cultural do Estado do Pará, legitima-se uma ideologia na estruturação do simbólico da cultura paraense. Por sua vez, a institucionalização de elementos identitários da gastronomia paraense em patrimônio cultural ao mesmo tempo em que reconhece a representatividade desses símbolos alimentares, deixa de considerar uma variedade de outros símbolos, e atende à lógica da patrimonialização global, para referenciar Costa (2009):

Isso faz com que o patrimônio seja procurado e encontrado em todo o mundo,
adquirindo uma visibilidade e importância inigualável na história, englobando tudo
o que é dotado de significado cultural irreplicável. Cultura que se transforma em
mercadoria na sociedade contemporânea, fazendo com que o patrimônio, cada vez
menos, represente o ideal de "Estado-nação" ou de diversidade cultural dos povos,
perdendo seu referencial de memória viva ao se tornar um produto em potencial do
desenvolvimento turístico, que tem o poder de banalizar pela cenarização
progressiva (COSTA, 2009, p. 48).

Da mesma forma, Maciel (2004, p. 27) corrobora essa ideia ao afirmar que "uma cozinha não pode ser reduzida a um inventário, a um repertório de ingredientes, nem convertida em fórmulas ou combinações de elementos cristalizados no tempo e no espaço". Dentro dessa perspectiva, as tradições que se expressam nas "comidas típicas" patrimonializadas como "pato com tucupi", "maniçoba", "tacacá" ao mesmo tempo que valorizam as tradições, por outro lado, reduzem a diversidade da gastronomia paraense a um inventário oficial composto por seis preparos tradicionais.

No entanto, deve-se considerar que preservar um patrimônio cultural não consiste em congelar no tempo uma determinada tradição. Albuquerque Jr. (2007, p. 17) lembra que “tradições são sempre invenções feitas por grupos humanos numa determinada época, não há algo tradicional desde sempre e nada do que é tradicional está isento de modificação, de transformação, a mudança cultural nem sempre necessita desses monstros externos para ocorrer".

Isso resulta numa preocupação necessária com a preservação e valorização do saberfazer tradicional e da percepção que o paraense tem de sua própria gastronomia. Nesse ponto, percebe-se uma contradição entre o discurso oficial que, em suma, fundamenta-se nos aspectos da autenticidade e originalidade, mas na prática rende-se aos aspectos da 
homogeneidade cultural. Esse fato pode ser identificado no material promocional que apresenta o "pato no tucupi" (figura 12) com uma roupagem estética destoante daquela que figura na própria descrição encontrada no portal Belemtur.

Figura 12 - Totem no saguão do Aeroporto Internacional de Belém

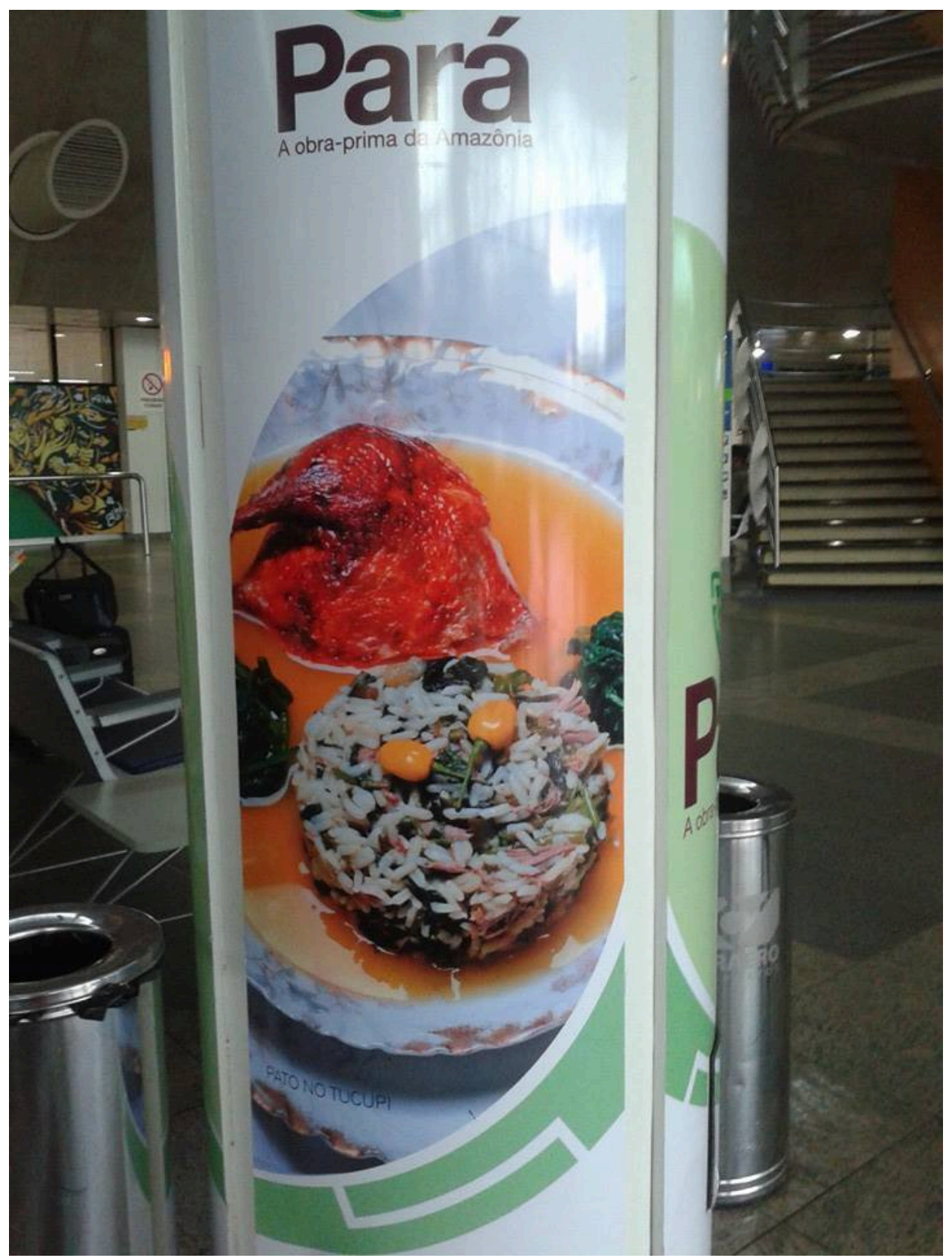

Fonte: Foto cedida por Tainá Marajoara (julho de 2014).

De modo a facilitar a compreensão, tradicionalmente, o pato no tucupi é constituído por três ingredientes principais: pato, tucupi e jambu. $\mathrm{O}$ pato, no preparo tradicional, depois de assado, é cortado em pedaços e fervido no tucupi e o jambu é apresentado sobre o pato. Como acompanhamentos, apenas arroz e farinha de mandioca. No entanto, a imagem promocional do pato no tucupi disposta no saguão do aeroporto da cidade, apresenta o 
preparo com um conceito estético que não retrata a cultura paraense ao mesmo tempo em que acrescenta e retira elementos do preparo. A técnica de preparo do pato é diferente da tradicional, o jambu ganha um novo lugar na apresentação e o arroz branco ganha um novo elemento e uma decoração extra (a pimenta). A farinha, símbolo do paraense, é excluída da imagem.

$\mathrm{Na}$ busca de referências sobre a identidade paraense, o discurso que a promove o estado como "obra-prima da Amazônia" é o mesmo que oculta a existência de elementos representativos da identidade local na imagem. Parece existir a tentativa da homogeneização cultural de um povo que, acima de tudo, se entende como comedor de farinha e que é representado pelos atributos identitários que o próprio Plano Ver-o-Pará elencou para a construção da marca turística do estado.

Se a gente tem o povo Marajoara com seis mil anos de história, com sua cerâmica sendo disputada no mundo inteiro porque não é um prato de cerâmica marajoara que tá lá? E se não é um prato de cerâmica marajoara porque não é uma cuia? Por que é um pato no tucupi com uma porcelana francesa? Qual é o discurso que aparece nessa imagem? Por que ela está colocada ali e se está ali está falando alguma coisa para alguém e o que ela fala enquanto imagem, ela afirma e ao mesmo tempo ela nega. É uma reflexão que o governo deveria fazer. (informação verbal) ${ }^{78}$

A constante contradição entre a estética da gastronomia paraense e a estética da gastronomia transformada em atrativo turístico é um dos principiais elementos identificados no decorrer desta pesquisa. Identifica-se uma conexão entre a gastronomia paraense que foi promovida oficialmente no aeroporto e a formulação do roteiro turístico-gastronômicocultural "Pará: 8 dias e 7 noites na Obra Prima da Amazônia" 79 desenvolvido pela Paratur/Setur e direcionado para o trade turístico com o objetivo de atingir as metas do Plano Ver-o-Pará. Percebe-se que num mesmo dia, o primeiro, o turista é estimulado a consumir o tradicional — café da manhã paraense - e o moderno e inovador — denominada de "gastronomia fusão". ${ }^{80}$

Em diversos momentos, os roteiros disponíveis promovem o consumo da gastronomia "tipicamente" paraense como parte da experiência turística e indicam "o que", "onde" e "quando" o turista deve consumi-la. O roteiro gastronômico estruturado para o Festival Ver-

\footnotetext{
${ }^{78}$ Depoimento de Tainá Marajoara concedido para a autora no dia 19 de abril de 2015 em Brasília-DF.

${ }^{79}$ O roteiro "Pará: 8 dias e 7 noites na Obra Prima da Amazônia" está disponível no site oficial da Paratur. Disponível em: <http://www.paraturismo.pa.gov.br>. Acesso em: 03 ago. 2014.

${ }^{80} \mathrm{O}$ conceito de gastronomia fusão (fusion) está relacionado com a possibilidade de ofertar ao commensal um preparo com técnicas e/ou ingredientes que retratem duas ou mais influências culturais.
} 
o-Peso $2015^{81}$ inclui no final da tarde a degustação dos "famosos sorvetes da Cairú" e do “emblemático Tacacá” (figura 12).

Figura 13 - O Tacacá paraense servido nas ruas de Belém

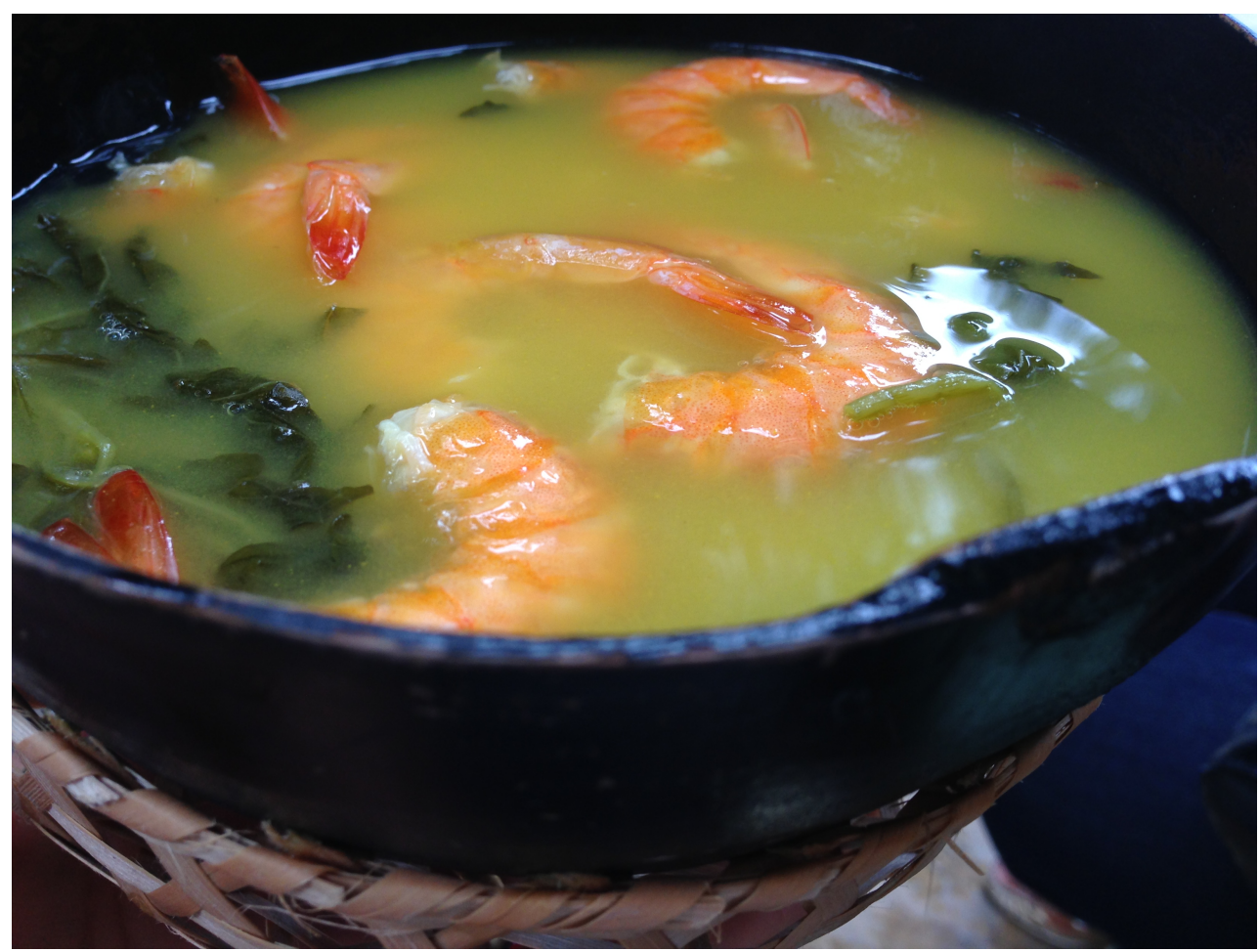

Fonte: Acervo da autora (abril de 2013).

É possível observar que os elementos que conferem identidade à gastronomia paraense são os elementos que a destacam no cenário nacional e internacional. Apoiada nos critérios de autenticidade e originalidade, o discurso da gastronomia paraense permeia o imaginário coletivo e direciona a construção da imagem institucionalizada no Plano Ver-o-Pará que tem como objetivo transformar o estado no destino turístico líder da Amazônia.

Por sua vez, a capital do estado, se destaca como polo para consumo e produção dessa identidade a partir dos seus mercados, feiras, ruas e restaurantes. Portanto, ao viajar para Belém em busca da experiência gastronômica, o turista é motivado a experimentar o patrimônio gastronômico local e a gastronomia inovadora. A pergunta que deixamos é se essas nuances visam atender à lógica sociedade do consumo ou se atendem às necessidades da sociedade que é produtora desse patrimônio cultural e dessa identidade.

\footnotetext{
${ }^{81}$ Disponível em http://www.veropesodacozinhaparaense.com.br/files/vop2015-pacote1.pdf. Acesso em: 30 mai. 2015.
} 


\section{EVIDÊNCIAS FINAIS}

Inquietam-nos os conceitos simplificadores que permeiam os estudos sobre gastronomia brasileira e a recorrente apropriação dos seus elementos identitários para fruição dos turistas. Partimos de uma interpretação conceitual para a gastronomia que procura contextualizar suas ações simbólicas à teia de significados da cultura com um viés materialista crítico sobre o papel da cultura na sociedade.

Para escapar do paradigma que entendemos simplificador, assumimos que a gastronomia é um fenômeno complexo que abrange dimensões subjetivas e objetivas, conscientes e inconscientes, materiais e simbólicas. Assim, entendemos necessário conceituála como a cultura alimentar que confere identidade a um determinado grupo (ou pessoa) imersa no contexto dos símbolos produzidos por sua própria cultura e continuamente transformada na medida em que sociedades se transformam. Ao considerar o caráter dinâmico das expressões culturais e suas constantes transformações, assumimos a tendência de hibridez que é atinente à nossa sociedade.

No contexto de uma sociedade pós-moderna, identificamos que as relações sociais são mediadas pelos símbolos e organizadas para conferir sentido e finalidade à própria sociedade. Nessa dinâmica, ocorre a formação de um sistema de representação cultural estruturado a partir das imbrincadas relações de poder vigentes na sociedade.

Como nos lembra Kosik (2002), a busca pela totalidade concreta do fenômeno exige um détour pois a essência do fenômeno não se manifesta imediatamente ao pesquisador. Portanto, para escaparmos do mundo da pseudoconcreticidade, percorremos um desvio que, a nosso ver, entendemos necessário para revelar o fenômeno e assim atingir a essência da dinâmica que atribui valor material e simbólico aos bens culturais e, consequentemente, à gastronomia.

O mundo da pseudoconcreticidade é um claro-escuro de verdade e engano. O seu elemento próprio é o duplo sentido. O fenômeno indica a essência e, ao mesmo tempo, a esconde. A essência se manifesta no fenômeno, mas só de modo inadequado, parcial, ou apenas sob certos ângulos e aspectos. O fenômeno indica algo que não é ele mesmo e vive apenas graças ao seu contrário. A essência não se dá imediatamente; é mediata ao fenômeno e, portanto, se manifesta em algo diferente daquilo que é. A essência se manifesta no fenômeno. O fato de se manifestar no fenômeno revela seu movimento e demonstra que a essência não é inerte nem passiva. Justamente por isso o fenômeno revela a essência. A manifestação da essência é precisamente a atividade do fenômeno. (KOSIK, 2002, p. 15) 
Nesse percurso, procuramos avançar sobre o discurso ideológico de uma identidade nacional - e gastronômica — formada pelo sincretismo cultural de indígenas, negros e portugueses. Diante dos múltiplos processos sócios-culturais vivenciados em território brasileiro desde o início da conturbada fase de colonização, revelamos as contradições entre a luta pelo controle territorial e a afirmação dos bens culturais na identidade nacional e no universo do patrimônio cultural brasileiro.

Assim, foi possível revelamos que a gastronomia reflete as estruturas de poder vigentes nos grupos sociais e, por esta razão, identifica e diferencia culturas. Sob essa concepção, podemos dizer que a estruturação da gastronomia paraense como atrativo turístico é resultado e resultante da sua expressão como patrimônio cultural ou bem comum daquele grupo social.

Neste contexto, entendemos que a produção e o consumo da gastronomia em Belém do Pará atende a lógica vigente na sociedade que coleciona espetáculos e busca os elementos que distinguem os bens culturais. Com base nisso, foi possível tecer um olhar critico sobre o discurso do Plano Ver-o-Pará que idealiza o "universo de cores e sabores" da gastronomia paraense como a mais "brasileira" do país.

Por sua vez, entendemos que a dimensão simbólica da gastronomia contradiz o discurso que afirma categorias de "autenticidade" e "originalidade" pois afirmar a existência de uma identidade mais autêntica, mais original ou mais brasileira seria o mesmo que dizer que entre as múltiplas identidades gastronômicas existentes no país, apenas a gastronomia paraense é original e as demais são inautênticas ou meras reproduções.

No contexto de uma sociedade espetacular, o turista passa a colecionar experiências que reafirmam o "gosto" da própria sociedade. Nesse contexto, a gastronomia configura-se como elemento motivador das viagens e passou a orientar o discurso dos agentes públicos e privados para promoção gastronômica dos destinos, incluindo neste caso, o Pará. A partir da experiência profissional da autora, observamos o frénésie em torno da gastronomia paraense e sua apropriação material e simbólica por diversos agentes públicos e privados para potencializar o turismo no Pará. Por sua vez, Belém se afirma como a cidade para fruição da "diversidade", "originalidade" e "autenticidade" da gastronomia paraense.

Nessa dinâmica, evidenciamos um massivo processo de mercantilização de um patrimônio cultural que muitas vezes é institucionalizado para atender as metas definidas pelo órgão oficial de turismo e que não leva em consideração a complexidade do turismo nesse planejamento. 
Cabe-nos dizer que o discurso oficial do Estado revela uma série de contradições na tentativa de ressignificar um patrimônio cultural e uma identidade gastronômica para atender as expectativas dos turistas. Nesta perspectiva, buscamos analisar, criticamente, o Plano Vero-Pará a partir do discurso que confere aos bens culturais status de "produtos" e que estabelece parâmetros mínimos de qualidades produção e comercialização dos produtos turísticos. Essa tendência, a nossa ver, revela um processo de padronização e homogeneização cultural.

A contradição existente entre a valorização dos elementos "puros" e "originais" da gastronomia paraense e sua comercialização como atrativo turístico passa a requer um esforço de resistência coletiva no sentido de definir instrumentos que possibilitem a salvaguarda do saber-fazer tradicional e do conjunto simbólico das práticas culturais identitárias. Nesse sentido, preocupa-nos a reprodução de modelos tomados como exemplos de destinos que atingiram o resultados positivos na promoção turística da gastronomia local.

Nosso objetivo não consiste em negar as múltiplas possibilidades que os bens culturais oferecem para o turismo e, tampouco, contestar o encantamento que o "exótico", isto é, a cultura do outro desperta nos turistas. No entanto, sob um enfoque crítico materialista, emerge a necessidade de apontarmos as contradições existentes entre a produção e consumo do patrimônio gastronômico como atrativo turístico.

Em nosso entendimento, o estado deve instituir instrumentos e alternativas que transcendam a busca incessante pela renda monopolista e possibilitem a participação da população local no processo valorização do seu patrimônio cultural. Assim, esperamos superar a pretensa verdade de que a ressignificação desse patrimônio afeta apenas positivamente as condições de vida da população local.

"Vida do Pará

Vida de descanso Comer de arremesso Dormir de balanço". (Frei João de São José, 1762) 


\section{REFERÊNCIAS}

ALBUQUERQUE JR., D. M. Fragmentos do discurso cultural: por uma análise crítica do discurso sobre a cultura no Brasil. In: NUSAUMER, G. M. (Ed.). . Teorias \& políticas da cultura - Visões Multidisciplinares. Coleção CULT. Salvador: UFBA, 2007.

BAUMAN, Z. Globalização: As consequências humanas. In: Traducao Marcus PENCHEL. Rio de Janeiro: Jorge Zahar, 1999.

BAUMAN, Z. Identidade - Entrevista a Benedetto Vecchi. Traducao Carlos Alberto MEDEIROS. Rio de Janeiro: ZAHAR, 2005.

BENEDICT, R. O crisântemo e a espada - padrões da cultura japonesa. São Paulo: Perspectiva, 1972.

BOTELHO, T. R. Patrimônio Cultura e Gestão das Cidades: Uma Análise da Lei do ICMS Cultural de Minas Gerais. Habitus, v. 4, n. 1, p. 471-492, 2006.

BOURDIEU, P. O poder simbólico. Traducao Fernando TOMAZ. Rio de Janeiro: Bertrand Brasil S.A., 1989.

BOURDIEU, P. A Distinção: crítica social do julgamento. Traducao Daniela KERN; Guilherme J. F. Teixeira TEIXEIRA. São Paulo: Edusp, 2007.

BRASIL. Constituição da República Federativa do Brasil de 1988, de outubro de 1988. Disponível em: $<$ http://www.planalto.gov.br/ccivil_03/constituicao/constituicaocompilado.htm>. Acesso em: 15 abr. 2015

BRASIL, G. DO E. DO P. Ver-o-Pará - Plano Estratégico de Turismo do Estado do Pará: 2012-2020 (Relatório Executivo), 2011. Disponível em: $<$ http://www.paraturismo.pa.gov.br/sites/default/files/Relatorio_Executivo.pdf $>$. Acesso em: 26 jul. 2014

BRILLAT, S. A fisiologia do gosto. Traducao Paulo NEVES. São Paulo: Companhia das Letras, 1995.

CAMINHA, P. V. DE. Carta a El-Rei D. Manuel sobre o achamento do Brasil. Lisboa: Printer Portuguesa, 1997.

CANCLINI, N. G. Culturas híbridas - Estrategias para entrar y salir de la modernidad. 1a. edición actualizada ed. Buenos Aires: Paidós, 2001.

CARNEIRO, H. Comida e Sociedade - Uma História da Alimentação. Rio de Janeiro: Campus, 2003.

CASCUDO, L. DA C. História da Alimentação no Brasil. 3a. ed. São Paulo: Global, 2004.

CASTANHO, T.; BIANCHI, L. Cozinha de Origem. São Paulo: Publifolha, 2013.

CERGO, J. A emergência das cozinhas regionais. In: História da Alimentação. São Paulo: Estação Liberdade, 1998. 
CHOAY, F. A alegoria do patrimônio. Traducao Luciano Vieira Machado. São Paulo: UNESO, 2001.

CLAVAL, P. Lieux de mémoire. Revista Espaço e Cultura, v. n.19, n. UERJ, p. 89-106, 2005.

CLAVAL, P. A Geografia Cultural. Traducao Luíz Fugazzola Pimenta e Margareth de Castro Afeche Pimenta. Florianóplis: Editora da UFSC, 2007.

COSTA, E. B. DA; SCARLATO, F. C. Patrimônio da Humanidade: Universalismo de um apoderamento territorial soberano. In: Valor Patrimonial e Turismo: Limiar entre História, Território e Poder. São Paulo: Outras Expressões, 2012.

COSTA, E. B. DA; SUZUKI, J. C. Materialismo Histórico e Existência - Discurso Geográfico e Utopias. Espaço e Geografia, v. 15, n. 1, 2012a.

COSTA, E. B. A Dialética da Construção Destrutiva na Consagração do Patrimônio Mundial: O Caso de Diamantina (MG). Dissertação de Mestrado — São Paulo: USP, 2009.

COSTA, E. B.; SUZUKI, J. C. A Ideologioa Espacial Constitutiva do Estado Nacional Brasileiro. Scripta Nova (Revista Electrónica de Geografía y Ciencias Sociales), Cuadernos Críticos de Geografía Humana. v. XVI, n. 418 (6), 2012 b.

CSERGO, J. A emergência das cozinhas regionais. In: História da Alimentação. São Paulo: Estação Liberdade, 1998.

DEBORD, G. A Sociedade do Espetáculo. Traducao Estela dos Santos ABREU. Rio de Janeiro: Contraponto, 1997.

DEL PRIORE, M.; VENÂNCIO, R. O livro de ouro da História do Brasil. Rio de Janeiro: Ediouro, 2001.

DÓRIA, C. A. Formação da culinária brasileira - Escritos sobre a cozinha insoneira. São Paulo: Três Estrelas, 2014.

FLANDRIN, J.-L. A Humanização das Condutas Alimentares. In: História da Alimentação. 7a. ed. São Paulo: Estação Liberdade, 1998.

EMBRATUR. Gastronomia à mesa com a EMBRATUR. , 27 mar. 2013. Disponível em: $<\mathrm{http}: / / \mathrm{www}$. youtube.com/watch? $\mathrm{v}=$ gemAf55cIUk>. Acesso em: 25 jul. 2013.

FLANDRIN, J.-L.; MONTANARI, M. História da alimentação. Traducao Luciano Vieria Machado; Guilherme J. F. Teixeiral. 7a. ed. São Paulo: Estação Liberdade, 1998.

FONSECA, M. C. L. O Patrimônio em Processo: trajetória da política federal de preservação no Brasil. Rio de Janeiro: UFRJ / MinC - IPHAN, 1997.

FRANCO, A. De caçador a gourmet. 3a. ed. revista e ampliada ed. São Paulo: Senac, 2004.

FREIXA, D.; CHAVES, G. Gastronomia no Brasil e no mundo. Rio de Janeiro: Senac Nacional, 2009. 
FREYRE, G. Casa-grande \& senzala: formação da família brasileira sob o regime da economia patriarcal. 51a. ed. São Paulo: Global, 2006.

FREYRE, G. Açúcar - Uma Sociologia do Doce, com Receitas de Bolos e Doces do Nordeste do Brasil. 5a. ed. São Paulo: Global, 2007.

GEERTZ, C. A Interpretação das Culturas. Traducao Fanny WROBEL. Rio de Janeiro: ZAHAR, 1978.

GONÇALVES, J. R. Autenticidade, Memória e Ideologias Nacionais: O problema dos patrimônios culturais. Estudos Históricos, v. 1, n. 2, p. 264-275, 1988.

HALL, S. A identidade cultural na pós-modernidade. Traducao Tomaz Tadeu DA SILVA; Guacira Lopes LOURO. Rio de Janeiro: Lamparina, 2014.

HARVEY, D. A Arte da Renda: A globalização e transformação da cultura em commodities. In: A Produção Capitalista do Espaço. Coleção Geografia e Adjacências. Traducao Carlos SZLAK. São Paulo: Annablume, 2005.

INSTITUTO BRASILEIRO DE GEOGRAFIA E ESTATÍSTICA. Brasil: 500 anos de povoamento. Rio de Janeiro: [s.n.].

KOSIK, K. Dialética do Concreto. 7a. ed. [s.1: s.n.].

LARAIA, R. DE B. Cultura - um conceito antropológico. Rio de Janeiro: Zahar, 1986.

LÉVI-STRAUSS, C. L'Origine Des Manières de Table - Mythologiques. Paris: Plon, 1968.

LÉVI-STRAUSS, C. O cru e o cozido. Traducao Beatriz PERRONE-MOISÉS. Rio de Janeiro: Cosac e Naify, 2004.

LÉVI-STRAUSS, C. Natureza e Cultura. Antropos - Revista de Antropologia, v. 3, Ano 2, p. 17 - 26, dezembro de 2009.

LÉVI-STRAUSS, C.; ANTÔNIO MARQUES BESSA. Mito e Sociedade. [s.1.] Editora 70, 1978.

MACHADO, M. H. P. T. A Construção Narrativa da Memória e a Construção das Narrativas Históricas: Panoramas e Perspectivas. In: DANILO SANTOS DE MIRANDA (Ed.). . Memória e Cultura - A importância da memória na formação cultural humana. São Paulo: Sesc-SP, 2007.

MACIEL, M. E. Uma cozinha à brasileira. Revista Estudos Históricos, v. 1 (Alimentação), n. 33, 2004.

MACIEL, M. E. Identidade Cultural e Alimentação. In: CANESQUI, A. M.; GARCIA, R. W. D. (Eds.). . Antropologia e Nutrição: um diálogo possível. Antropologia e Saúde. Rio de Janeiro: Fiocruz, 2005a.

MACIEL, M. E. Identidade Cultural e Alimentação. In: CANESQUI, A. M.; GARCIA, R. W. D. (Eds.). . Antropologia e nutrição: um diálogo possível. Identidade Cultural e Alimentação. Coleção Antropologia e Saúde. Rio de Janeiro: Fiocruz, 2005b. p. 49-55. 
MARAJOARA, T. Elementos simbólicos da gastronomia paraense, 19 maio 2015.

MENESES, U. B. Os paradoxos da memória. In: Memória e Cultura - A importância da memória na formação cultural humana. São Paulo: Sesc-SP, 2007.

MOESCH, M. M. Epistemologia Social do Turismo. São Paulo: USP, 2004.

MOESH, M. A produção do saber turístico. Campinas: Contexto, 2000.

MONTANARI, M. Sistemas alimentares e modelos de civilização. In: História da Alimentação. São Paulo: Estação Liberdade, 1998.

MORIN, E. Introdução ao pensamento complexo. Traducao Eliane Lisboa. 4a. ed. Porto Alegre: Sulina, 2011.

NORA, P. Entre Memória e História: A problemática dos Lugares. Projeto História, n. 10, p. 7-28, 1993.

OLIVEIRA, J. P. DE; FREIRE, C. A. DA R. A presença indígena na formação do Brasil. Brasília: Ministério da Educação, Secretaria de Educação Continuada, Alfabetização e Diversidade: LACED/Museu Nacioal, 2006.

ORTIZ, R. Cultura e brasileira e identidade nacional. São Paulo: Brasiliense, 2012.

PERLÉS, C. As estratégias alimentares nos tempos pré-históricos. In: História da Alimentação. São Paulo: Estação Liberdade, 1998.

RIBEIRO, D. O povo brasileiro. São Paulo: Companhia de Bolso, 2006.

RODRIGUES, M. De quem é o patrimônio? Um olhar sobre a prática preservacionista em São Paulo. Revista do Patrimônio Histórico e Artístico Nacional, v. 24, p. 195-203, 1996.

SACHS, I. Caminhos para o desenvolvimento sustentável. 3a. ed. Rio de Janeiro: Garamond, 2008.

SANTOS, J. L. DOS. O que é cultura. 16a. ed. São Paulo: Brasiliense, 1996.

SCHLÜTER, R. G. Gastronomia e Turismo. Traducao Roberto Sperling. São Paulo: Aleph, 2003. v. Coleção ABC do Turismo

TAMASO, I. Preservação dos Patrimônios Culturais: Diretiros Antinômicos, Situações Ambíguas. Anuário Antropológico, v. 98, p. 11-50, 2002.

UNESCO. Dossier de Candidature $N^{\circ} 00437$ pour I 'inscription sur la Liste Représentative du Patrimoine Culturel Immatériel en 2010, 2010.

URRY, J. O olhar do turista: lazer e viagens nas sociedades contemporâneas. 3a. ed. São Paulo: Studio Nobel : SESC, 2001.

WILKINS, J.; HILL, S. Archestratus - Fragments from The Life of Luxury. [s.1.] Prospect Books, 2011. 